Prepared for the U.S. Department of Energy

under Contract DE-AC05-76RL01830

\title{
Renewable Energy Opportunities at Fort Sill, Oklahoma
}

\author{
BK Boyd JR Hand RJ Nesse, Project Manager \\ JA Horner AC Orrell \\ BJ Russo MR Weimar
}

March 2011

Pacific Northwest

NATIONAL LABORATORY

Proudly Operated by Battelle Since 1965 


\title{
DISCLAIMER
}

United States Government. Neither the United States Government nor any agency thereof, nor Battelle Memorial Institute, nor any of their employees, makes any warranty, express or implied, or assumes any legal liability or responsibility for the accuracy, completeness, or usefulness of any information, apparatus, product, or process disclosed, or represents that its use would not infringe privately owned rights. Reference herein to any specific commercial product, process, or service by trade name, trademark, manufacturer, or otherwise does not necessarily constitute or imply its endorsement, recommendation, or favoring by the United States Government or any agency thereof, or Battelle Memorial Institute. The views and opinions of authors expressed herein do not necessarily state or reflect those of the United States Government or any agency thereof.

\author{
PACIFIC NORTHWEST NATIONAL LABORATORY \\ operated by \\ BATTELLE \\ for the \\ UNITED STATES DEPARTMENT OF ENERGY \\ under Contract DE-AC05-76RL01830
}

Printed in the United States of America
Available to DOE and DOE contractors from the
Office of Scientific and Technical Information,
P.O. Box 62, Oak Ridge, TN 37831-0062;
ph: (865) 576-8401, fax: (865) 576-5728
email: reports@adonis.osti.gov

Available to the public from the National Technical Information Service,

U.S. Department of Commerce, 5285 Port Royal Rd., Springfield, VA 22161

ph: (800) 553-6847, fax: (703) 605-6900

email: orders@ntis.fedworld.gov

online ordering: http://www.ntis.gov/ordering.htm

This document was printed on recycled paper.

$(8 / 00)$ 
PNNL-20222

\title{
Renewable Energy Opportunities at Fort Sill, Oklahoma
}

\author{
BK Boyd JR Hand RJ Nesse, Project Manager \\ JA Horner AC Orrell \\ BJ Russo MR Weimar
}

March 2011

Prepared for

the U.S. Army Installation Management Command Headquarters under Contract DE-AC05-76RL01830

Pacific Northwest National Laboratory

Richland, Washington 99352 
Renewable Energy Opportunities at Fort Sill, Oklahoma

Pacific Northwest National Laboratory, March 2011 


\section{Executive Summary}

Increasing use of renewable energy is mandated by several Executive Orders and legislation. The goal of this report is to help Army personnel make sense of renewable energy at Fort Sill.

This document provides an overview of renewable resource potential at Fort Sill, based primarily upon analysis of secondary data sources supplemented with limited on-site evaluations. This effort focuses on grid-connected generation of electricity from renewable energy sources and on ground source heat pumps for heating and cooling buildings. The effort was funded by the U.S. Army Installation Management Command (IMCOM) as follow-on to the 2005 Department of Defense (DoD) Renewables Assessment. The site visit to Fort Sill took place on June 10, 2010.

At this time, some renewable technologies show economic potential at Fort Sill. Project feasibility is based on installation-specific resource availability and energy costs and projections based on accepted life-cycle cost methods. The most promising opportunity is wind, waste to energy (WTE), landfill gas, shale gas, and the continued use of ground source heat pumps (GSHPs). Waste to energy projects are potentially limited by emission regulations and landfill gas may be feasible in the near to mid future. Lastly, the results of this initial shale gas resource survey suggest that this resource should be examined more closely.

\section{Ground Source Heat Pumps}

The cost-effectiveness of retrofitting existing heating, ventilating, and air conditioning (HVAC) systems with GSHPs on Fort Sill was evaluated using the Facility Energy Decision System (FEDS) building energy modeling program. FEDS analyzed open-loop, horizontal closed-loop, and vertical closed-loop GSHPs based on data from a 2009 Pacific Northwest National Laboratory (PNNL) data-gathering trip. GSHPs were found to be cost-effective for a number of building groups. Although Fort Sill has more heating-degree-days than cooling-degree-days, many buildings at Fort Sill have relatively balanced heating and cooling loads because of internal heat gains (e.g., electrical equipment, motors, etc.). Open-loop systems were found to be the most cost-effective, followed by horizontal- and then vertical-loop systems. Simple paybacks ranged from 5 to 16 years.

\section{Waste to Energy}

Although Fort Sill is currently unable to consider a WTE project because of emissions concerns, a handful of scenarios showed somewhat favorable economics. Two different technologies, gasification and combustion, were examined for this analysis. Gasification is more efficient than combustion, but not as mature or common in commercial operation as combustion. At Fort Sill, scenarios utilizing gasification were slightly more economical. Fortunately, gasification plants produce fewer emissions than combustion plants and are likely more suitable for the site. Plants ranging in size from 23 to 59-MW were evaluated and had savings to investment ratios ranging from 0.6 to 1.0 , respectively.

Landfill gas may also be practical at Fort Sill. Initial analyses suggested that a 0.75-MW landfill gas power plant could produce electricity at $6 \varnothing / \mathrm{kWh}$. Although this is higher than the current electric rate, it remains a feasible resource that could be considered in five to ten years. 
Wind

Fort Sill has a moderately high wind energy potential. With the site's wind resource and the current cost assumptions, the marginal electric rate would need to be between 13 and $57 \phi / \mathrm{kWh}$ to provide a $10 \%$ internal rate of return, depending on the scale of the wind turbine considered. Although this is substantially more than the current electric rate at Fort Sill, wind energy is still a notable resource for the site, and it may be feasible to develop wind turbines in the near to mid future. Using funding from the Energy Investment and Conservation Program, the savings to investment ratios ranged from 0.0 to 0.99 . If capital costs decrease, more incentives become available, and/or utility rates increase, Fort Sill should reevaluate wind energy project economics. Alternatively, Fort Sill could consider pursuing a demonstration or energy security project because the site has many ideal characteristics for this type of development.

\section{Other Renewable Resources}

Other renewable technologies did not prove to be cost-effective with current conditions and assumptions. Other large biomass generation projects using dedicated energy crops, animal waste, other industrial waste, and wastewater treatment plant sludge are impractical at this time because of insufficient feedstock availability. Projects involving the use of biomass fuels such as crop residues, animal waste, and dedicated energy crops are also not feasible because of their inability to support economic electricity generation. Solar projects are not likely to be costeffective in the near future either, requiring an energy cost of 30 to $40 \phi / \mathrm{kWh}$ to achieve a $10 \%$ internal rate of return. Also, there is no known high-temperature geothermal resource on or near Fort Sill.

Lastly, Fort Sill personnel are aware of the shale gas potential in areas surrounding the site, and as a result, the site requested that PNNL perform a cursory review of existing literature to determine if there may be a shale gas resource. These resources indicate that Fort Sill is located within the Wichita uplift, a geologic sub-province of the Interior Plains of the Midwestern United States. The Anadarko Basin, which bounds the northern flank of the Wichita Mountains and contains a small portion of the northeast corner of Fort Sill, is a deep, resource-rich basin that has been explored extensively across southwestern Oklahoma. A detailed map from the Oklahoma Geological Survey of oil and gas fields located near Fort Sill shows that several fields are present near the eastern edge of the site. It is recommended that additional investigations be pursued into the shale gas opportunities at Fort Sill.

Renewable resources with at least some potential for being economic are summarized in Table 1. 
Table 1: Summary of Promising Renewable Energy Projects at Fort Sill

\begin{tabular}{|c|c|c|c|c|c|c|c|c|}
\hline & $\begin{array}{c}\text { Renewable } \\
\text { Resource and } \\
\text { Technology } \\
\end{array}$ & \begin{tabular}{|l} 
Resource \\
Estimate
\end{tabular} & $\begin{array}{c}\text { Earliest } \\
\text { Output }\end{array}$ & Figures of Merit & $\begin{array}{l}\text { Financing } \\
\text { Mechanisms } \\
\text { Evaluated } \\
\end{array}$ & Location--Requirements & Key Assumptions & $\begin{array}{l}\text { Next Steps } \\
\text { Comments }\end{array}$ \\
\hline 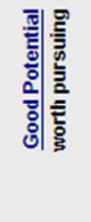 & $\begin{array}{l}\text { Ground } \\
\text { Source Heat } \\
\text { Pump } \\
\text { (Thermal } \\
\text { Energy) }\end{array}$ & TBD & 2011 & $\begin{array}{l}\text { ECIP scenario: } \\
\text { SIR: } 1.0-3.3 \\
\text { SPB: } 10.4-13.4\end{array}$ & $\begin{array}{l}\text { ECIP } \\
\text { IPP } \\
\text { UESC } \\
\text { ESPC }\end{array}$ & $\begin{array}{c}\text { Adequate heat sources } \\
\text { and sinks proximate to } \\
\text { GSHPS }\end{array}$ & $\begin{array}{l}\text { There are buildings } \\
\text { that require heating } \\
\text { and potentially cooling } \\
\text { Suitable land area and } \\
\text { soil characteristics for } \\
\text { closed loop GSHPS. }\end{array}$ & $\begin{array}{l}\text { Suite surveys to } \\
\text { determine whether } \\
\text { suitable heat sinks } \\
\text { and sources exist, } \\
\text { and to provide the } \\
\text { detailed soil } \\
\text { characterization to } \\
\text { base system design. }\end{array}$ \\
\hline \multirow{3}{*}{ 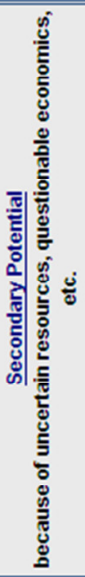 } & $\begin{array}{l}\text { Landfill Gas } \\
\text { Energy Plant }\end{array}$ & $0.8 \mathrm{MW}$ & 2013 & $\begin{array}{c}\text { IPP scenario: } \\
6.0 \mathrm{c} / \mathrm{kWh} \text { breakeven } \\
\text { rate }\end{array}$ & $\begin{array}{l}\text { ECIP } \\
\mathrm{IPP}\end{array}$ & $\begin{array}{l}\text { A productive, lined } \\
\text { landfill with space for a } \\
\text { power plant and gas } \\
\text { pipe and access to } \\
\text { transmission lines. }\end{array}$ & $\begin{array}{l}\text { Adequate gas for the } \\
\text { plant sized selected. }\end{array}$ & $\begin{array}{l}\text { Confirm waste } \\
\text { availability and gas } \\
\text { production. }\end{array}$ \\
\hline & $\begin{array}{l}\text { Waste to } \\
\text { Energy }\end{array}$ & $\begin{array}{r}23-59 \\
\text { MW }\end{array}$ & 2013 & $\begin{array}{c}\text { SIR: } 0.6-1.0 \\
\text { SPB: } 15-22 \text { years }\end{array}$ & IPP & $\begin{array}{l}\text { A } 5 \text {-acre site near major } \\
\text { roads, a utility } \\
\text { substation, water, } \\
\text { sewage, and an } \\
\text { appropriate industrial } \\
\text { infrastructure }\end{array}$ & $\begin{array}{l}\text { Adequate MSW for the } \\
\text { plant sized selected. } \\
50 \% \text { of tipping fees } \\
\text { available with MSW to } \\
\text { plant. }\end{array}$ & $\begin{array}{l}\text { Confirm waste } \\
\text { availability and } \\
\text { tipping fees. } \\
\text { Economics are highly } \\
\text { dependent upon } \\
\text { tipping fee available } \\
\text { from waste providers. } \\
\text { Examine emissions }\end{array}$ \\
\hline & $\begin{array}{l}\text { Utility Grade } \\
\text { Wind Farm \& } \\
\text { Small Scale } \\
\text { Wind }\end{array}$ & $\begin{array}{c}2.4 \mathrm{~kW}-1.5 \\
\text { MW } \\
\text { installed } \\
\text { capacity }\end{array}$ & 2012 & $\begin{array}{l}\text { IPP scenario }=13- \\
60 \% / \mathrm{kWh} \text { break even } \\
\text { rate } \\
\text { ECIP scenario: } \\
\text { SIR: negative }-1.0 \\
\text { SPB: } 14.4 \text { - negative }\end{array}$ & $\begin{array}{l}\text { ECIP } \\
\text { IPP }\end{array}$ & $\begin{array}{l}\text { Projects need to be } \\
\text { located within } \\
\text { approximately } 1 \text { mile of } \\
\text { existing transmission } \\
\text { lines, or new lines will } \\
\text { need to be constructed } \\
\text { and away from active } \\
\text { aifields. }\end{array}$ & $\begin{array}{l}\text { Proposed project will } \\
\text { not interfere with any } \\
\text { on-site systems. }\end{array}$ & $\begin{array}{l}\text { If incentives become } \\
\text { available or there is a } \\
\text { rate increase, the } \\
\text { feasibility of a wind } \\
\text { project should be } \\
\text { reevaluated }\end{array}$ \\
\hline
\end{tabular}

ECIP = Energy Conservation Investment Program, SIR = savings-to-investment ratio, $\mathrm{SPB}=$ simple payback, IPP = independent power producer, UESC $=$ utility energy services contract, ESPC $=$ energy savings performance contract 
Pacific Northwest National Laboratory, March 2011 


\section{Table of Contents}

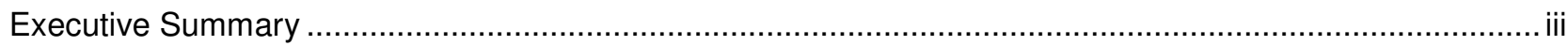

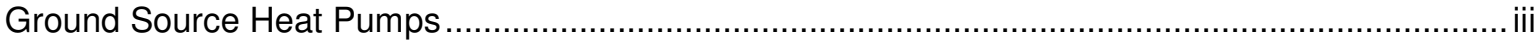

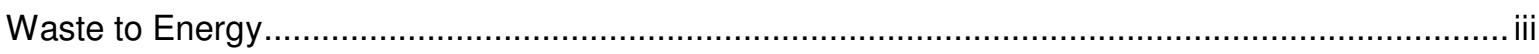

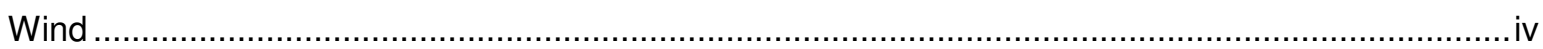

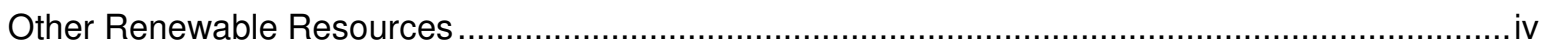

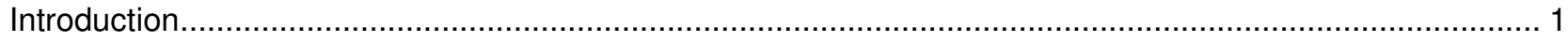

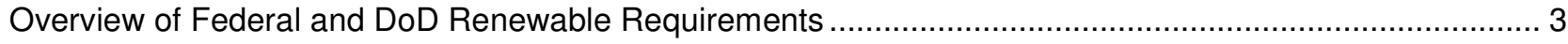

Approach for Identifying, Analyzing, and Implementing Renewable Energy Projects ...................... 5

Importance of Financing Mechanisms for Project Feasibility.................................................... 6

The Political and Economic Environment for Renewables at Fort Sill .......................................... 6

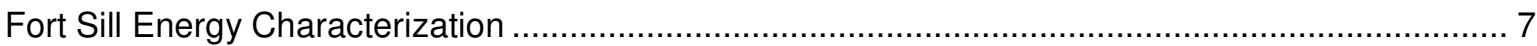

State Incentives for Renewable Project Development................................................................ 7

Federal Incentives for Renewable Project Development.......................................................... 8

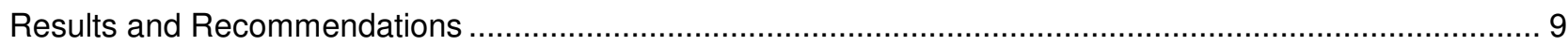

Ground Source Heat Pump Findings and Recommendations .................................................. 10

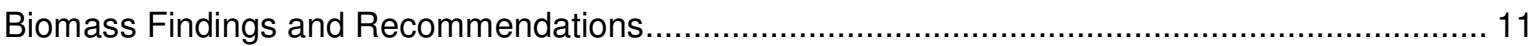

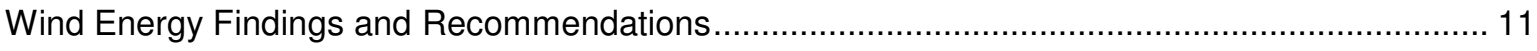

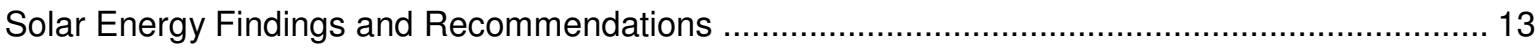

Waste-to-Energy Findings and Recommendations ........................................................... 13

Geothermal Power Findings and Recommendations ............................................................... 14

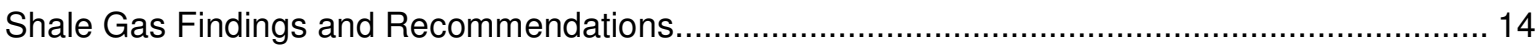

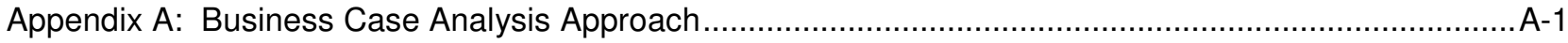

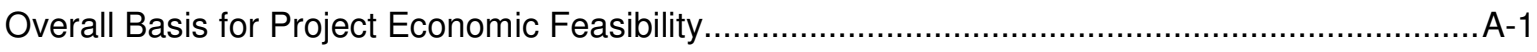

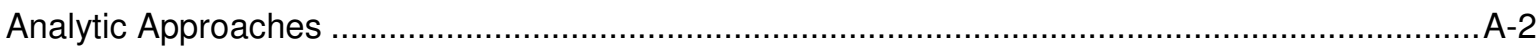

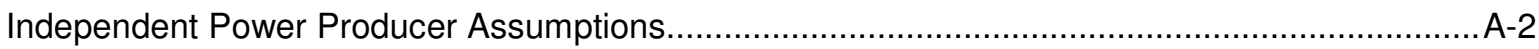

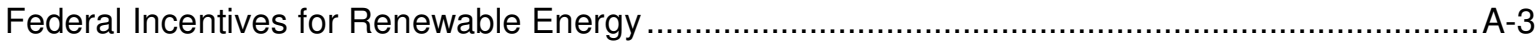

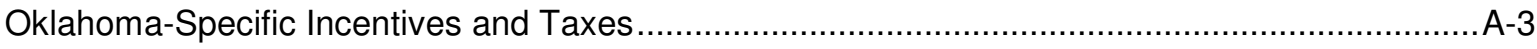

Other Independent Power Producer Assumptions ................................................................

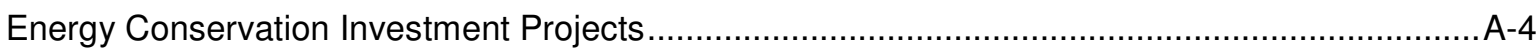

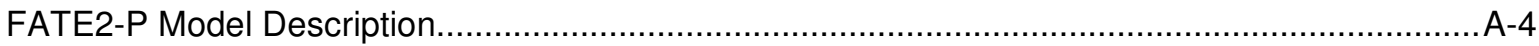

Private Ownership Rate of Return Methodology ................................................................ A -5

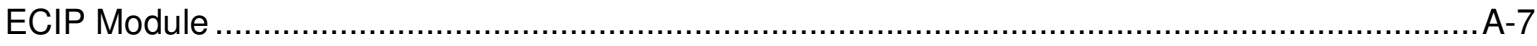

The Facility Energy Decision System (FEDS) Model ........................................................

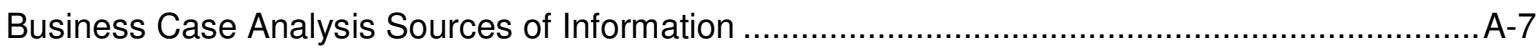

Appendix B: Analysis of Biomass and Waste-to-Energy Opportunities ................................................ 
Biomass and Waste-to-Energy Technology ........................................................................

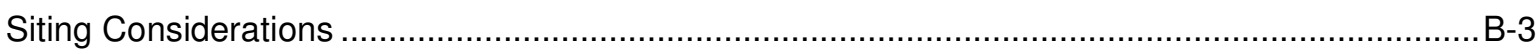

Biomass and Waste-to-Energy Analysis Approach .................................................................

Biomass and Waste Resource Characterization ................................................................... $\mathrm{B}-5$

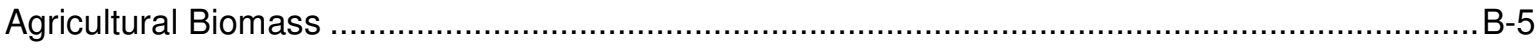

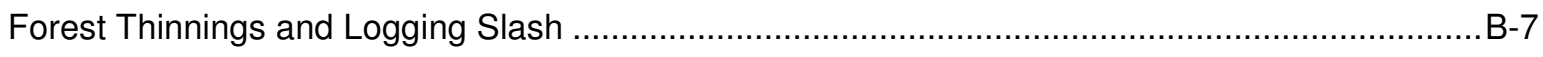

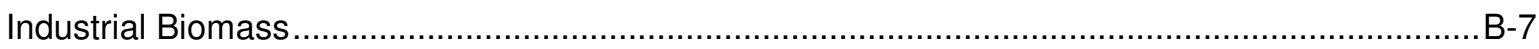

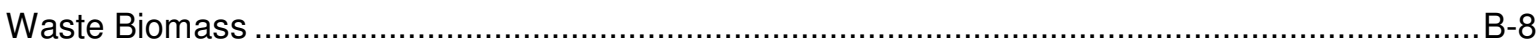

Biomass and Waste-to-Energy: Economic and Other Analysis Parameters ............................... B-10

Findings: Biomass and Waste-to-Energy Opportunities .............................................................

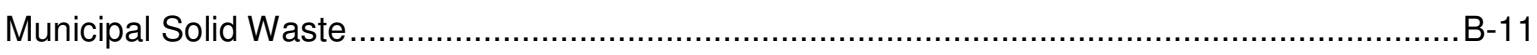

Biomass and Waste-to-Energy: Next Steps........................................................................

Biomass and Waste-to-Energy Sources of Information .............................................................

Appendix C: Analysis of Geothermal Power Plant Opportunities ..........................................................

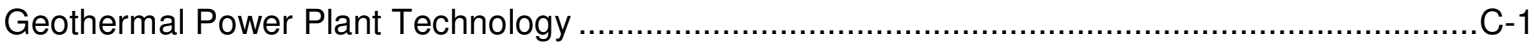

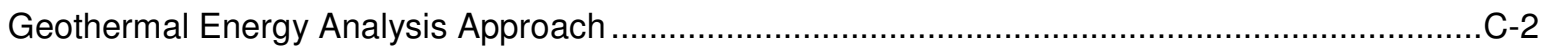

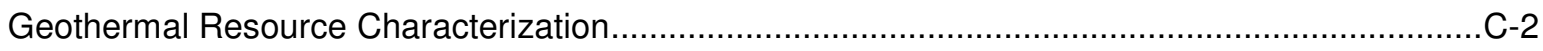

Geothermal Power Plants: Economic and Other Analysis Parameters ............................................

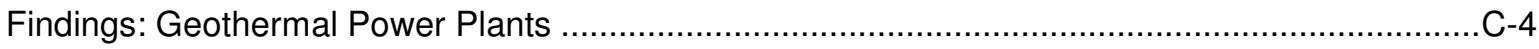

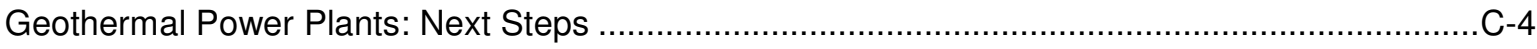

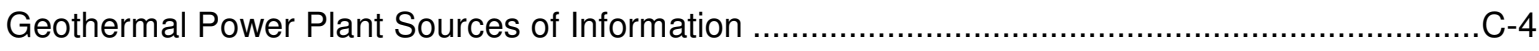

Appendix D: Analysis of Ground Source Heat Pump Opportunities ..................................................... 1

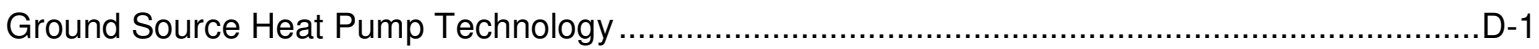

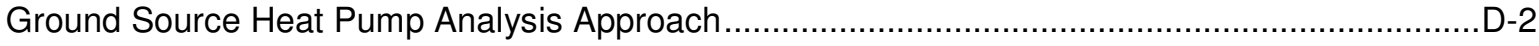

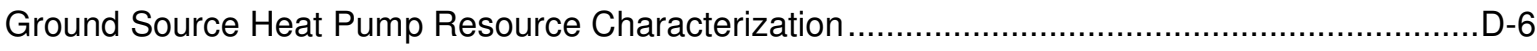

Ground Source Heat Pumps: Economic and Other Analysis Parameters...................................

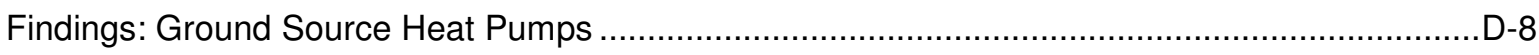

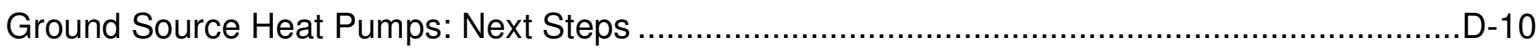

Ground Source Heat Pump Sources of Information ...............................................................

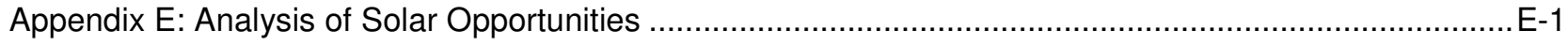

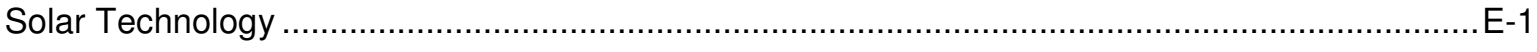

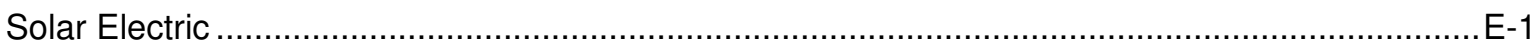

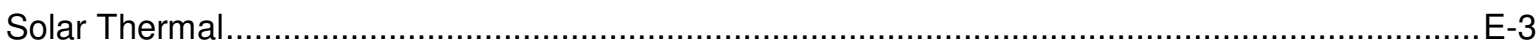

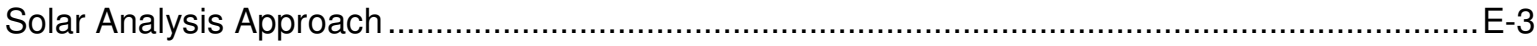

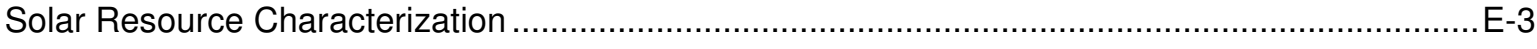

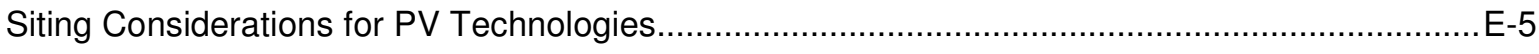

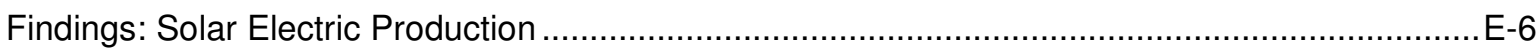




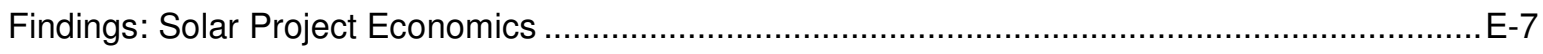

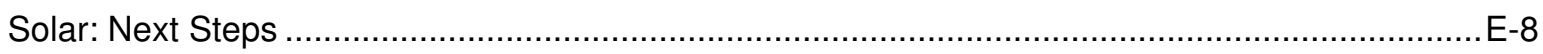

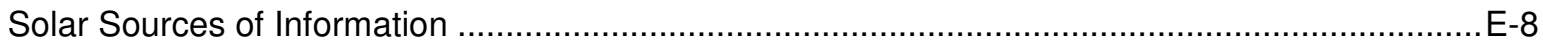

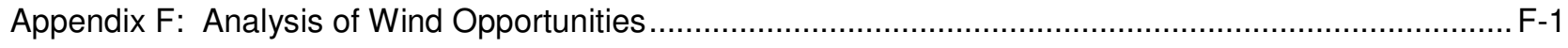

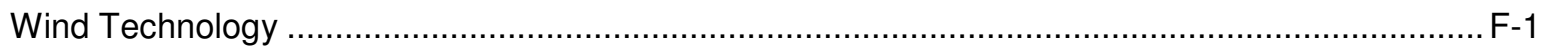

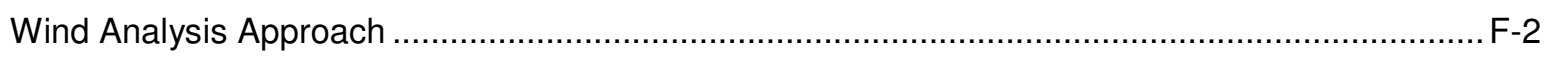

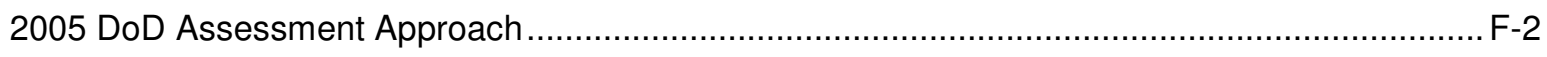

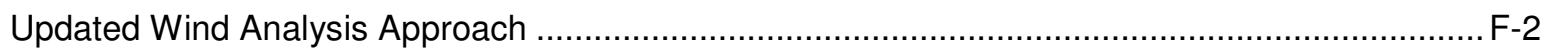

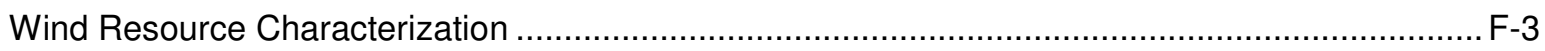

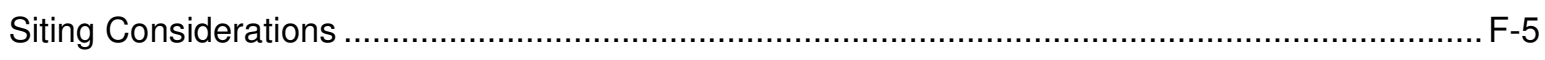

Wind: Economic and Other Analysis Parameters ...............................................................

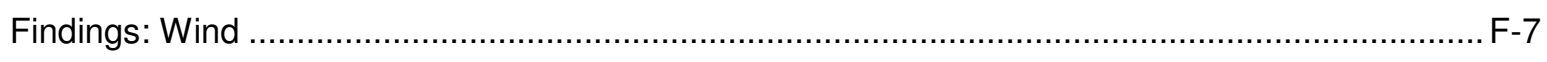

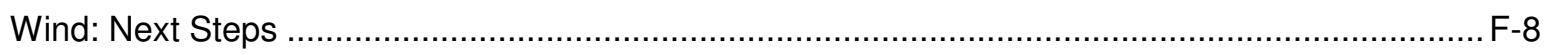

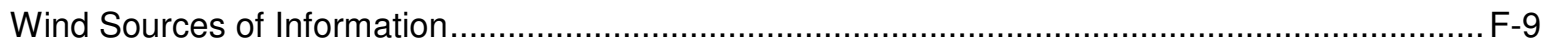

Appendix G: Analysis of Shale Gas Opportunities ......................................................................... G-1

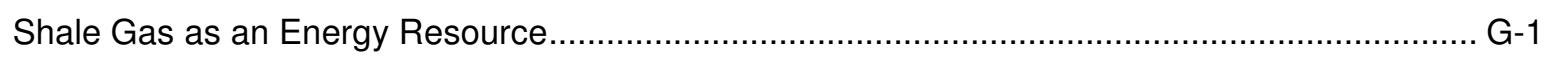

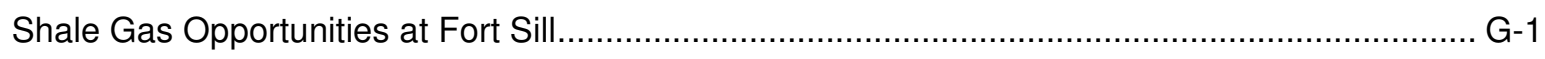

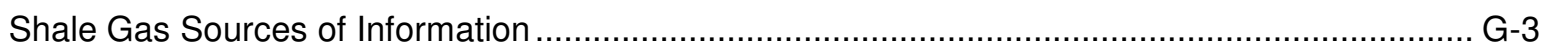




\section{Figures}

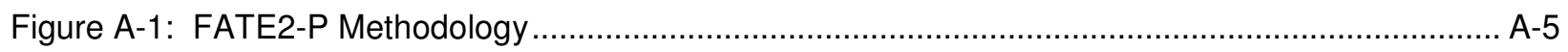

Figure C-1: Location of Boreholes with Published Geothermal Data Near Fort Sill, Oklahoma.............. C-3

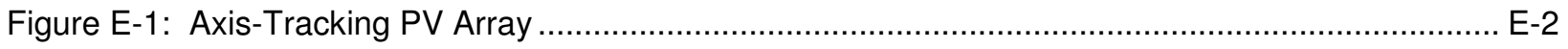

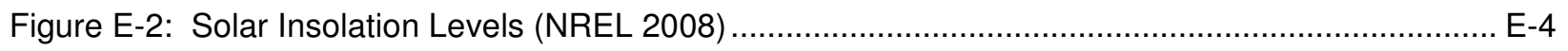

Figure E-3: Average Daily Insolation at Fort Sill ............................................................................... E-5

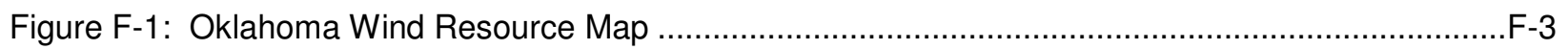

Figure F- 2: Fort Sill OSU Wind Resource Map..........................................................................

Figure G-1: Major Shale Gas Basins and Active Shale Gas Plays Located Near Fort Sill, Oklahoma (EIA 2010a)

Figure G-2: Oil and Gas Fields Located Near Fort Sill, Oklahoma (Boyd 2002) .................................3 


\section{Tables}

Table 1: Summary of Promising Renewable Energy Projects at Fort Sill............................................ v

Table 2: Legislated Renewable Energy Targets for DoD ......................................................................... 3

Table 3: Summary of Fort Sill Renewable Energy Opportunities ......................................................... 9

Table 4: Simple Payback Periods for Building Groups Analyzed in FEDS* ......................................... 10

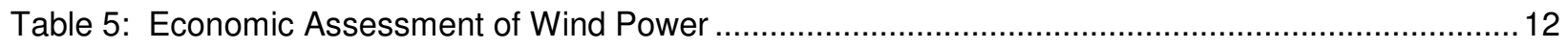

Table 6: Economic Results for Solar Technologies ...................................................................... 13

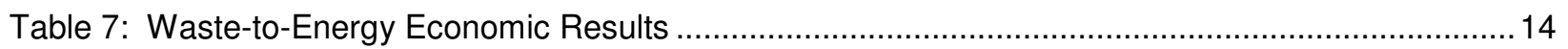

Table A-1: MACRS Depreciation Rates for Renewable Energy Projects ......................................... A-3

Table A-2: Discount Rate Assumptions in the ECIP Model ............................................................ A-4

Table B-1: Crops and Biomass Production near Fort Sill ........................................................... B-6

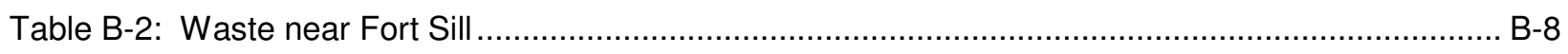

Table B-3: Economic Assumptions, constant $\$ 2010$.................................................................... B-11

Table B-4: Site and Regional MSW Waste-to-Energy Results ....................................................... B-12

Table D-1: Building Groups Analyzed in FEDS for GSHPs ........................................................ D-3

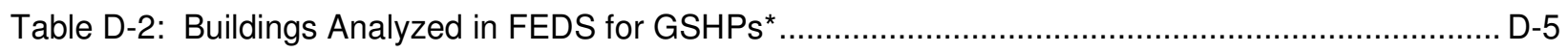

Table D-3: Simple Payback Period for Building Groups Analyzed in FEDS for GSHPs ...................... D-8

Table E-1: Monthly Averaged Insolation Incident on a South-Facing Tilted Surface at Fort Sill

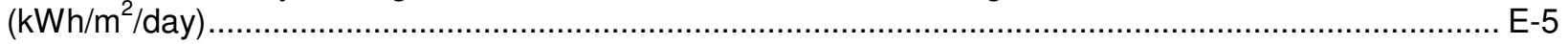

Table E-2: Solar Electric Production by System Type at Fort Sill ................................................... E-7

Table E-3: Economic Results for Solar Technologies at Fort Sill ..................................................... E-8

Table F-1: Classes of Wind Power Density at 50 Meters ................................................................

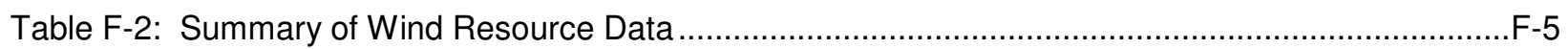

Table F-3: Performance, Cost, and Economic Characteristics ..........................................................

Table F-4: Economic Assessment of Wind Power........................................................................... 


\section{Introduction}

Pacific Northwest National Laboratory (PNNL) has been directed by the U.S. Army Installation Management Command (IMCOM) to conduct detailed analyses of the potential for electricity generation at selected U.S. Army installations. The goal of the analyses is to identify economically feasible opportunities for generation of electricity from renewable resourcesgeneration that is significant enough to warrant connection to the grid and/or to contribute in a meaningful way to the aggressive renewable energy goals of the Army and the Department of Defense (DoD).

In 2005, PNNL led a study to identify utility-scale electricity generation opportunities at DoD installations. That study focused on solar, wind, and geothermal. A limited number of attractive large-scale commercial opportunities were identified, and their implementation is now being pursued. The study also identified a number of potential smaller opportunities that needed to be investigated further before project implementation decisions could be made.

This analysis of opportunities at Fort Sill, Oklahoma is one of a suite of analyses being conducted at Army installations as follow-on to the 2005 study. The goal is to revisit potential renewable opportunities and focus on projects with a size of at least 1-MW, updating the analysis for changes in economics, incentives, knowledge about the available renewable resource, and other factors. In addition, IMCOM has directed PNNL to evaluate the potential for biomass, waste to energy, and retrofitting heating and cooling systems in existing buildings with ground source heat pumps (GSHPs). Retrofitting with GSHPs is obviously not an electricity generation opportunity, but it is an opportunity for significant energy savings and replacement of fossil fuels across the DoD. In addition, shale gas development is typically for thermal fuel generation, although electricity can be generated in a manner similar to land fill gas. As part of the analysis, IMCOM has directed PNNL to lay out the steps necessary to implement the project opportunities that are identified.

The overall findings of this analysis are summarized in the main body of the report. The business case approach that underlies the analysis of each renewable technology is documented in Appendix A. Appendix B describes the analysis conducted on biomass and waste to energy technologies. Appendix C describes the geothermal analysis; Appendix D, the GSHP analysis; Appendix E, the solar analysis; Appendix F, the wind energy analysis; and Appendix J, shale gas analysis. 


\section{Overview of Federal and DoD Renewable Requirements}

The Army needs to satisfy multiple goals and constraints while securing its energy suppliesfocusing on procurement of the lowest-cost energy that meets high reliability standards and minimum vulnerability to interruption from natural or intentional causes. Overlaid on this challenge is the need to comply with a series of somewhat contradictory statutes and policies, as laid out in Table 2. These include:

- Energy Policy Act (EPAct) Section 203. This law mandates the minimum contribution of renewable electricity to an installation's total electricity consumption. The target fractions are 3\% for FY 2007 through FY 2009, 5\% through FY 2012, and not less than $7.5 \%$ beginning in FY 2013.

- Executive Order (EO) 13423. The Executive Order reiterates the EPAct goals; however, it uses a different basis than EPAct for measuring and crediting progress. For example, renewable thermal energy counts toward the renewable goal.

- National Defense Authorization Act (NDAA). The NDAA codifies DoD's voluntary goal of $25 \%$ by 2025 , but does not include any interim targets. Renewable thermal energy counts toward the renewable goal.

- Energy Independence and Security Act (EISA). EISA established two additional renewable goals for new buildings and retrofits. One requires $30 \%$ of domestic hot water to be supplied from solar energy, and the other requires all fossil fuels used in buildings to be displaced by 2030. This is not a power generation goal like the others, but is important to note.

Table 2: Legislated Renewable Energy Targets for DoD

\begin{tabular}{|l|c|c|c|c|}
\hline & $\begin{array}{c}\text { EPAct Section } \\
\mathbf{2 0 3}\end{array}$ & $\begin{array}{c}\text { Executive Order } \\
\mathbf{1 3 4 2 3}\end{array}$ & $\begin{array}{c}\text { National Defense } \\
\text { Authorization } \\
\text { Act }\end{array}$ & $\begin{array}{c}\text { Energy } \\
\text { Independence } \\
\text { and Security Act }\end{array}$ \\
\hline Target / Goal & $\begin{array}{c}\text { Increasing targets } \\
\text { reaching 7.5\% of } \\
\text { electric energy } \\
\text { from renewables }\end{array}$ & $\begin{array}{c}7.5 \% \text { of electric } \\
\text { energy from } \\
\text { renewables; 50\% } \\
\text { from new (post- } \\
\text { 1998) sources }\end{array}$ & $\begin{array}{c}\text { Equivalent of } \\
25 \% \text { of electric } \\
\text { energy from } \\
\text { renewables }\end{array}$ & $\begin{array}{c}\text { 30\% of hot water } \\
\text { demand from } \\
\text { solar }\end{array}$ \\
\hline Target Dates & 2013 & 2013 & 2025 & $\begin{array}{c}\text { All new } \\
\text { construction / } \\
\text { major renovations }\end{array}$ \\
\hline Mandatory? & Yes & Yes & No & Yes \\
\hline $\begin{array}{l}\text { Considers thermal } \\
\text { energy "renewable"? }\end{array}$ & No & Yes & Yes & N/A \\
\hline \hline
\end{tabular}

This assessment is primarily for renewable energy provision and retrofit applications in existing buildings. Accordingly, potential in new building construction is mentioned only in passing. The Department of Energy (DOE) is responsible for developing guidance for EPAct and EO 13423. DOE's guidelines for EO compliance, unlike EPAct, allow credit for renewable energy 
that reduces electricity use from thermal sources; however, it adds a requirement that at least $50 \%$ of renewable energy must come from "new" resources: those put into service after January $1,1999$.

Congress did not provide a definition of "renewable" in the NDAA language, and DOE is not responsible for establishing DoD or Army policies to achieve the goals in the NDAA. The current Army energy strategy and associated draft renewable policy takes an expansive view of renewables that encompasses thermal energy from renewable sources. As a result, the Army needs to proceed in a way that makes sense for the Army in a good faith effort to satisfy Congressional, Administration, and Pentagon mandates and directives. The expectation is that the Army will meet the stricter definitions of EPAct on its way to meeting the much higher renewable goals of the NDAA.Analysis of Renewables at Fort Sill

PNNL's renewable energy analysis includes a preliminary assessment based on readily available information sources, a site visit to present the preliminary findings and gather additional information, and a concluding assessment, which is documented in this report.

The site visit to Fort Sill took place on June 10, 2010 with Bryan Russo and Ron Nesse attending for PNNL. Fort Sill personnel at the briefing included Michael Baird, the site's resource efficiency manager, and Christopher Brown, the site's energy manager. 


\section{Approach for Identifying, Analyzing, and Implementing Renewable Energy Projects}

Renewable energy resources are unlike conventional resources because the "fuel" is essentially free. However, harnessing this free resource requires substantial investment in resource exploration, characterization, and collection; project development; and ongoing maintenance and operation. A renewable resource is like purchasing a new car with a lifetime of fuel as part of the purchase agreement. First costs are much higher, but total cost may be lower over the long run.

Economic development of renewable energy depends upon:

- Access to a renewable resource,

- Development costs, and

- Financing that is economically attractive and allowed by Federal and DoD regulations.

Each of these is critically important.

Naturally, a renewable resource has to be available and accessible to be developed. The best resources are those with the greatest potential for displacing conventional fuels or power supplies. Development cost, however, is the great equalizer, and a project based upon an excellent resource located many miles away may be inferior to a project based upon a lesser resource nearby. For example, an excellent wind resource far from an adequate transmission line may be less attractive than an inferior resource adjacent to a transmission line. Similarly, waste resources that could be used in a central plant may not be economic, even if they are "free," if the transportation, handling, and storage costs are greater than the cost of continued use of conventional heating fuels.

Development costs are relatively comparable for similar size projects, irrespective of resource quality. This is why the quality of the resource is so important-namely for the same investment, you get more out of a high quality resource than a lower quality one. But, development costs also include access to transmission capacity for shipping power to users, or alternatively, access to a retail customer. This is a critical difference, because power shipped over transmission lines has to compete with the prevailing wholesale price for power from conventional resources. Typically, renewables are not competitive in these markets, unless a buyer specifically demands renewable power. On the other hand, if the power can be used onsite to displace power purchased from the local utility, it competes against that customer's retail power price or utility rate. Because retail power prices include costs for transmission, distribution, and administrative costs, they are higher than wholesale power prices and make competing renewable projects more attractive economically.

It is important that economic analyses of renewable energy opportunities use realistic data on avoided energy costs, project costs, and available incentive funds, if any. A common analytic mistake is the use of average cost per $\mathrm{kWh}$ - the so-called "blended" rate. Using the blended rate will lead to inaccurate results when a renewable resource is intermittent (as is the case with wind and solar resources) because intermittent resources cannot be guaranteed to reduce peak demand. Even non-intermittent resources may not result in reduced peak demand because of 
periodic maintenance shutdowns and unscheduled outages. The economic analyses in this report use only the energy component of the power bill ("marginal rate") to evaluate intermittent resources, which is admittedly conservative. The blended rate is used for economic analysis of base-load resources.

Additionally, the installation's utility may impose a standby or other fee in the face of a major on-site generation project that needs to be reflected in the project's cost calculation. The analyses conducted here make no assumptions regarding standby charges, because those are typically assessed on a project-by-project basis.

The economic analyses in this report used two perspectives: Energy Conservation Investment Program (ECIP) funding and third-party financing. Under the latter arrangement, power is sold through a contract that is commonly called a power purchase agreement (PPA). This analysis assumed an internal rate of return (IRR) of $10 \%$ is the minimum required to attract a developer. The ECIP analyses assumed projects were not cost-effective if the savings-to-investment ratio (SIR) was less than 1.0. These two options are the lowest-cost among all the options typically available to Army customers.

\section{Importance of Financing Mechanisms for Project Feasibility}

Financing is a critical determinant of development costs because the high first costs are sensitive to financial factors such as incentive payments, tax breaks, and interest rates. Incentive payments and tax breaks reduce first costs, lowering both the overall project cost and interest costs. Because financing is so critical, project economics (payback rates, life-cycle costs, etc.) constitute the best initial screen for project potential. That screen needs to reflect various financing alternatives, which in turn, helps energy managers decide on the best project development approach.

This study focuses on large projects on the premise that if a good renewable resource exists at a site, it should be developed to its maximum potential. Projects smaller than 1-MW are not analyzed except for special cases. The large projects analyzed typically exceed any realistic expectation for appropriated funding, and so the assessments also consider commercial (thirdparty) development of projects. Besides funding limitations, there are other reasons that these large projects should be implemented by third-party investors - under current DoD philosophy, resource development is not a core DoD mission and should be left to the private sector. In addition, private developers can take advantage of tax credits, and they value renewable energy credits (RECs) more highly than the Army does. As a result, letting the developers claim tax credits and retain RECs, if available, will reduce the cost of energy to the installation if the developer is selling power from the project to the site.

\section{The Political and Economic Environment for Renewables at Fort Sill}

Fort Sill is blessed with relatively low cost electricity and natural gas. Ultimately, this is beneficial to the Army and DoD, although it does pose a challenge to executing cost-effective renewable energy projects. Moreover, the renewable energy incentives for Oklahoma are limited and marginal, which poses further challenges to renewable energy project development. 
In addition to naturally low cost energy, another challenge at Fort Sill concerns emissions. Fort Sill currently has a synthetic minor emission permit. However, the site is nearly at the maximum allowable emissions limit for this permit. Substantial increase in emissions will require the site to pursue a full Title 5 emission permit. Renewable energy projects that result in an increase of emissions, such as a combustion waste to energy plant, may require the site to apply for a new permit, which can be a challenging and difficult process.

\section{Fort Sill Energy Characterization}

The Southwestern Area Power Administration (SWAPA) charges Fort Sill a base electric rate of $\$ 0.013$ per all kilowatt-hours and an additional $\$ 0.0082 / \mathrm{kWh}$ for peaking and supplemental kilowatt-hours. There is a purchased power adder of $\$ 0.0067 / \mathrm{kWh}$ per peak kilowatt-hour. Demand charges were $\$ 3.51 / \mathrm{kW}$. Over FY 2009, the average blended rate for SWAPA was $\$ 0.026 / \mathrm{kWh}$. Public Service Company (PSO) charges Fort Sill a base rate of $\$ 0.036 / \mathrm{kWh}$, a fuel adjustment charge, which averaged $-\$ 0.002 / \mathrm{kWh}$ in FY 2009. Demand charges varied between $\$ 4.00$ to $\$ 4.45$ per $\mathrm{kW}$. A $70 \%$ ratchet is applied to the demand. In addition, each month has an individual peak demand charge of $\$ 0.60$ to $\$ 0.65$ per kW. Over FY 2009, the average blended rate for PSO was $\$ 0.054 / \mathrm{kWh}$. Several facilities located in Fort Sill's range lands are served by the Cotton Electric COOP. There are over a dozen meters served by the COOP and at various rates. During FY 2009, Fort Sill purchased 2,359 MWh from Cotton Electric COOP at an average rate of $\$ 0.086 / \mathrm{kWh}$.

Biomass, geothermal, and waste to energy power projects are capable of consistently and reliably delivering electricity. As a result, these systems are able to displace both electricity and peak power charges, and therefore displace electricity at the blended rate value. Because the amount of energy needed from PSO varies from less than 1 megawatt-hour to over 10 megawatt-hours over the year, biomass, geothermal, and waste to energy renewable energy projects were assumed to displace both SWAPA and PSO derived electricity at an average blended rate of $\$ 0.037 / \mathrm{kWh}$.

Solar and wind renewable energy resources would displace the direct energy (kWh) charge, or the marginal rate. These technologies cannot reliably reduce a site's peak demand and its associated charges. Consequently, they cannot be assumed to displace electricity at the blended rate, which includes demand and energy charges. However, because these projects are sized to be approximately 1-MW in size, they are suitable to potentially displace the more expensive electricity from Cotton Electric COOP because the wind and photovoltaic (PV) systems produce electricity on the order of the amount purchased from the COOP. PV and wind projects were evaluated using an electric rate of $\$ 0.086 / \mathrm{kWh}$.

Lastly, in FY 2009, Fort Sill consumed 1,466,910 MMBtus of natural gas at a cost of \$9.57/MMBtu.

\section{State Incentives for Renewable Project Development}

State incentives for renewable energy in Oklahoma include a small production based incentive for wind and solar projects and a renewable portfolio goal (RPG). These incentives are explained in detail in Appendix A. 


\section{Federal Incentives for Renewable Project Development}

Federal incentives for renewable energy include investment tax credits for corporations, significantly accelerated depreciation of equipment, and production tax credits. A $30 \%$ tax credit is available for PV projects, and $10 \%$ for geothermal and biomass electricity projects, with no incentive limits. The credits may be taken on equipment placed in service prior to January 1 , 2017. Wind is not eligible for the business energy tax credit. The tax basis for depreciation must be reduced by the amount of any Federal subsidy used in the financing of the eligible equipment.

Depreciation for most renewable energy equipment qualifies for significantly accelerated depreciation. For solar, wind, and geothermal, the modified accelerated cost recovery system (MACRS) provides for 5-year recovery of the cost of equipment. The 5-year recovery period does not apply to biomass or WTE equipment.

The renewable energy production tax credit (PTC), originally established in 1992, provides a tax credit for each kilowatt-hour of electricity produced. The PTC has been allowed to lapse and has then been renewed several times. Currently, the PTC is $2.1 \phi / \mathrm{kWh}$ for wind, geothermal, and closed-loop biomass (biomass that is grown with the sole purpose of being used to generate energy) and can be taken for 10 years. The PTC is $1.1 \phi / \mathrm{kWh}$ for electricity produced from openloop biomass and municipal solid waste (MSW) resources and can be taken for 5 years. Solar electricity generation has been excluded for equipment placed in service after December 2005.

Available tax incentives reduce the first-year costs of qualified renewable projects. The lower first cost also reduces the amount of money that must be borrowed to develop a project and thus, the associated interest and carrying costs. The combination reduces the delivered cost of power if developed by a private party with a tax obligation. Government-owned projects do not benefit from tax-based incentives. All of the PPA analyses conducted in this report assume that the PTC and other tax credits will be available when the equipment is placed in service. 


\section{Results and Recommendations}

A summary of analysis results is presented in Table 3, broken down into economic (green), marginal (yellow), or uneconomic (red) projects. The underlying analyses and recommendations for each of these technologies and potential projects are provided in the following subsections.

Table 3: Summary of Fort Sill Renewable Energy Opportunities

\begin{tabular}{|c|c|c|c|c|c|c|c|c|}
\hline & $\begin{array}{l}\text { Renewable } \\
\text { Resource and } \\
\text { Technology } \\
\end{array}$ & $\begin{array}{c}\text { Resource } \\
\text { Estimate }\end{array}$ & $\begin{array}{c}\text { Earliest } \\
\text { Output } \\
\end{array}$ & Figures of Merit & $\begin{array}{l}\text { Financing } \\
\text { Mechanisms } \\
\text { Evaluated } \\
\end{array}$ & Location--Requirements & Key Assumptions & $\begin{array}{l}\text { Next Steps } \\
\text { Comments }\end{array}$ \\
\hline 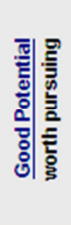 & $\begin{array}{l}\text { Ground } \\
\text { Source Heat } \\
\text { Pump } \\
\text { (Thermal } \\
\text { Energy) }\end{array}$ & TBD & 2011 & $\begin{array}{l}\text { ECIP scenario: } \\
\text { SIR: } 1.0-3.3 \\
\text { SPB: } 10.4-13.4\end{array}$ & $\begin{array}{l}\text { ECIP } \\
\text { IPP } \\
\text { UESC } \\
\text { ESPC }\end{array}$ & $\begin{array}{c}\text { Adequate heat sources } \\
\text { and sinks proximate to } \\
\text { GSHPs }\end{array}$ & $\begin{array}{l}\text { There are buildings } \\
\text { that require heating } \\
\text { and potentially cooling. } \\
\text { Suitable land area and } \\
\text { soil characteristics for } \\
\text { closed loop GSHPs. }\end{array}$ & $\begin{array}{l}\text { Suite surveys to } \\
\text { determine whether } \\
\text { suitable heat sinks } \\
\text { and sources exist, } \\
\text { and to provide the } \\
\text { detailed soil } \\
\text { characterization to } \\
\text { base system design. }\end{array}$ \\
\hline \multirow{3}{*}{ 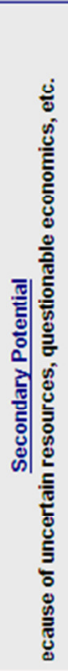 } & $\begin{array}{l}\text { Landfill Gas } \\
\text { Energy Plant }\end{array}$ & $0.8 \mathrm{MW}$ & 2013 & $\begin{array}{c}\text { IPP scenario: } \\
6.0 \phi / \text { WWh breakeven } \\
\text { rate }\end{array}$ & $\begin{array}{l}\text { ECIP } \\
\text { IPP }\end{array}$ & $\begin{array}{l}\text { A productive, lined } \\
\text { landfill with space for a } \\
\text { power plant and gas } \\
\text { pipe and access to } \\
\text { transmission lines. }\end{array}$ & $\begin{array}{l}\text { Adequate gas for the } \\
\text { plant sized selected. }\end{array}$ & $\begin{array}{l}\text { Confirm waste } \\
\text { availability and gas } \\
\text { production. }\end{array}$ \\
\hline & $\begin{array}{l}\text { Waste to } \\
\text { Energy }\end{array}$ & $\begin{array}{r}23-59 \\
\text { MW }\end{array}$ & 2013 & $\begin{array}{l}\text { SIR: } 0.6-1.0 \\
\text { SPB: } 15-22 \text { years }\end{array}$ & IPP & $\begin{array}{l}\text { A 5-acre site near major } \\
\text { roads, a utility } \\
\text { substation, water, } \\
\text { sewage, and an } \\
\text { appropriate industrial } \\
\text { infrastructure }\end{array}$ & $\begin{array}{l}\text { Adequate MSW for the } \\
\text { plant sized selected. } \\
50 \% \text { of tipping fees } \\
\text { available with MSW to } \\
\text { plant. }\end{array}$ & $\begin{array}{l}\text { Confirm waste } \\
\text { availability and } \\
\text { tipping fees. } \\
\text { Economics are highly } \\
\text { dependent upon } \\
\text { tipping fee available } \\
\text { from waste providers. } \\
\text { Examine emissions } \\
\text { concerns. }\end{array}$ \\
\hline & $\begin{array}{l}\text { Utility Grade } \\
\text { Wind Farm \& } \\
\text { Small Scale } \\
\text { Wind }\end{array}$ & $\begin{array}{c}2.4 \mathrm{~kW}-1.5 \\
\text { MW } \\
\text { installed } \\
\text { capacity }\end{array}$ & 2012 & $\begin{array}{c}\text { IPP scenario }=13 \text { - } \\
60 \mathrm{c} / \mathrm{kWh} \text { break even } \\
\text { rate } \\
\text { ECIP scenario: } \\
\text { SIR: negative }-1.0 \\
\text { SPB: } 14.4 \text { - negative }\end{array}$ & $\begin{array}{l}\text { ECIP } \\
\text { IPP }\end{array}$ & $\begin{array}{l}\text { Projects need to be } \\
\text { located within } \\
\text { approximately } 1 \text { mile of } \\
\text { existing transmission } \\
\text { lines, or new lines will } \\
\text { need to be constructed } \\
\text { and away from active } \\
\text { airfields. }\end{array}$ & $\begin{array}{l}\text { Proposed project will } \\
\text { not interfere with any } \\
\text { on-site systems. }\end{array}$ & $\begin{array}{l}\text { If incentives become } \\
\text { available or there is a } \\
\text { rate increase, the } \\
\text { feasibility of a wind } \\
\text { project should be } \\
\text { reevaluated }\end{array}$ \\
\hline \multirow{3}{*}{ 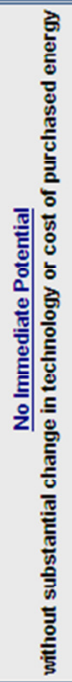 } & $\begin{array}{l}\text { Utility-Grade } \\
\text { Solar Electric } \\
\text { Power Plant }\end{array}$ & $\begin{array}{c}1 \text { MW (or } \\
\text { more if } \\
\text { space is } \\
\text { available) }\end{array}$ & 2012 & $\begin{array}{c}10 \% \text { IPP scenarios: } 31 \\
40 \text { c/kWh break even } \\
\text { rates } \\
\text { ECIP scenarios: } \\
\text { SIR: } 0.0 \\
\text { SPB: indeterminate }\end{array}$ & $\begin{array}{l}\text { ECIP } \\
\text { IPP }\end{array}$ & $\begin{array}{l}\text { Small scale: rooftops } \\
\text { (especially when } \\
\text { replacing rooftops), open } \\
\text { ground areas with } \\
\text { minimal shading or } \\
\text { concerns over } \\
\text { vandalism. } \\
\text { Large scale: near high } \\
\text { voltage transmission } \\
\text { lines, adequate open } \\
\text { space for array and } \\
\text { inverter system } \\
\end{array}$ & $\begin{array}{l}\text { Proposed project will } \\
\text { not interfere with any } \\
\text { on-site systems. }\end{array}$ & $\begin{array}{l}\text { PV via an ECIP is not } \\
\text { viable. Wait for a } \\
\text { Renewable Portfolio } \\
\text { Standard (RPS) in } \\
\text { enacted, electric } \\
\text { rates increase, or PV } \\
\text { capital costs } \\
\text { decrease. REC sales } \\
\text { are possible and } \\
\text { snould be } \\
\text { considered. }\end{array}$ \\
\hline & $\begin{array}{l}\text { Biomass } \\
\text { Generation } \\
\text { Plant }\end{array}$ & $\begin{array}{l}19 \text { MW of } \\
\text { available } \\
\text { crop waste. } \\
\text { Insufficient } \\
\text { fuel from } \\
\text { other } \\
\text { potential } \\
\text { sources. }\end{array}$ & 2013 & $\begin{array}{c}\text { IPP scenario: } 11 \mathrm{c} / \mathrm{kWh} \\
\text { breakeven rate }\end{array}$ & IPP & $\begin{array}{l}\text { A 5-acre site near major } \\
\text { rods, a utility substation, } \\
\text { water, sewage, and an } \\
\text { appropriate industrial } \\
\text { infrastructure, plus } \\
\text { feedstock storage space }\end{array}$ & $\begin{array}{l}\text { Off-site crops will be } \\
\text { available for } \$ 20 \text { per } \\
\text { ton, sufficient on-site } \\
\text { storage is available }\end{array}$ & $\begin{array}{l}\text { Do not pursue this } \\
\text { technology unless } \\
\text { electric rates } \\
\text { increase. }\end{array}$ \\
\hline & $\begin{array}{l}\text { High } \\
\text { Temperature } \\
\text { Geothermal } \\
\text { Generation } \\
\end{array}$ & NA & NA & NA & NA & NA & $\begin{array}{l}\text { No known high } \\
\text { temperature resource }\end{array}$ & $\begin{array}{l}\text { Nothing unless a } \\
\text { viable geothermal } \\
\text { resource is } \\
\text { discovered. }\end{array}$ \\
\hline
\end{tabular}

ECIP = Energy Conservation Investment Program, SIR = savings-to-investment ratio, $\mathrm{SPB}=$ simple payback, IPP = independent power producer, UESC $=$ utility energy services contract, ESPC $=$ energy savings performance contract 


\section{Ground Source Heat Pump Findings and Recommendations}

The cost-effectiveness of retrofitting existing heating, ventilating, and air conditioning (HVAC) systems with GSHPs on Fort Sill was evaluated using the Facility Energy Decision System (FEDS) building energy modeling program. FEDS analyzed open-loop, horizontal closed-loop, and vertical closed-loop GSHPs for using data from a 2009 PNNL data-gathering trip.

GSHPs were found to be cost-effective for a number building groups. GSHPs work well in buildings with relatively balanced heating and cooling loads because the installed capacity can be fully utilized in both the summer and winter. Although Fort Sill has more heating-degreedays than cooling-degree-days, many buildings at Fort Sill have relatively balanced heating and cooling loads because of internal heat gains (e.g., electrical equipment, motors, etc.). Open-loop systems were found to be the most cost-effective, followed by horizontal and then vertical-loop systems. Projects were identified for buildings with natural gas and central heat. All of the costeffective GSHP projects were found in buildings that are cooled with electric package units, as shown in Table 4.

Table 4: Simple Payback Periods for Building Groups Analyzed in FEDS*

\begin{tabular}{||l|c|c|c|c|c|c|c||}
\hline \multirow{2}{*}{ Description } & \multirow{2}{*}{ Group ID } & \multicolumn{2}{c|}{ Alternative Financing } & \multicolumn{3}{c||}{ Appropriated Financing } \\
\cline { 3 - 9 } & & Open & Horz & Vert+† & Open & Horz & Vert \\
\hline 1920s Small Admin & $10 \mathrm{~g}$ & - & - & - & 14.2 & - & - \\
\hline 1960s Small Admin & $10 \mathrm{~h}$ & - & - & - & - & 15.5 & - \\
\hline Modern Small Admin & $10 \mathrm{j}$ & - & - & - & - & 11.8 & - \\
\hline Medical Clinics & $21 \mathrm{~b}$ & - & - & - & 15.1 & 15.2 & - \\
\hline Large Simulation (high bay areas) & $23 \mathrm{~b}-2$ & 5.2 & 6.3 & - & 4.5 & 5.8 & 14.4 \\
\hline WWI Barracks & $30 \mathrm{a}$ & 10.5 & - & - & 8.1 & 16.5 & - \\
\hline Early 1980s barracks & $30 \mathrm{~b}$ & 10.7 & - & - & 10.9 & - & - \\
\hline 1950s Barracks (hammerheads) & $30 \mathrm{f}$ & - & - & - & 21.0 & - & - \\
\hline Historic Barracks & $30 \mathrm{~g}$ & - & - & - & 11.9 & 11.6 & 18.1 \\
\hline WWII Barracks & $30 \mathrm{j}$ & 15.3 & - & - & 17.4 & 13.3 & - \\
\hline Small Vehicle Maintenance & $50 \mathrm{c}$ & - & - & - & - & 15.1 & - \\
\hline Medium Vehicle Maintenance & $50 \mathrm{~d}$ & - & - & - & 15.8 & - & - \\
\hline Small Older Vehicle Maintenance & $50 \mathrm{e}$ & 13.1 & 11.8 & - & 10.8 & 10.2 & - \\
\hline Medium Older Vehicle Maintenance & $50 \mathrm{f}$ & 8.0 & 11.4 & - & 7.6 & 11.6 & - \\
\hline Police / Fire Buildings & $60 \mathrm{~b}$ & - & - & - & 13.0 & 17.0 & - \\
\hline Small Exchange Facilities & $60 \mathrm{c}$ & - & - & - & 7.4 & 7.3 & 13.3 \\
\hline Recreation Centers - Club House & $80 \mathrm{a}$ & - & - & - & - & 11.1 & - \\
\hline Museum / MWR & $80 \mathrm{~d}$ & - & - & - & - & 16.3 & - \\
\hline
\end{tabular}

* Building groups with no economically feasible projects are not included in this list, ** Open-loop GSHP

$\dagger$ Horizontal closed-loop GSHP, $\uparrow \uparrow$ Vertical closed-loop GSHP

With ECIP funding, open-loop and horizontal closed-loop systems were found to be costeffective most often. For buildings with natural gas heating, GSHP projects have simple payback periods as short as 4.5 years for high bay spaces and as high as 21.0 years for $1950 \mathrm{~s}$ 
vintage barracks. GSHPs were found to be able to cost-effectively replace a range of heating and cooling technologies, and there is no technology pair that clearly presents the best economic results, although the economics tend to be better when replacing older, inefficient equipment.

With alternative financed projects, the return on investment must be better than with ECIP funded projects, so fewer options are cost-effective. A handful of projects replacing natural gas and central heating were found to be cost-effective. No projects were found to be cost-effective for vertical closed-loop systems. Paybacks range from 5.2 to 15.3 years for open-loop systems, and from 6.3 to 11.8 years for horizontal-loop systems. Suitable buildings include the same high bay identified for alternative financing, several barracks, and various maintenance facilities.

The building-specific results should be investigated for available land area for heat exchanger wells or loops to determine whether a GSHP is practical to install in each recommended location. Lastly, given Fort Sill's imbalance between heating and cooling-degree-days, hybrid GSHPs should be considered. Detailed results of these analyses are provided in Appendix D.

\section{Biomass Findings and Recommendations}

Animal waste, cellulosic biomass, dedicated energy crops, crop residue, and other industrial waste are all inadequate to consider for a large biomass generation project.

Wheat and sorghum crop residue was found to be the best option for Fort Sill. With the combined waste stream of these two crops, a 19-MW gasification plant could be supported and would produce electricity at $11 \phi / \mathrm{kWh}$. This is considerably higher than the blended electric rate at Fort Sill.

Animal waste was not practical because the only animal waste stream available was from pastured beef cattle, which is not a suitable because waste for pastured cattle is typically not collected, and collecting this waste is not cost-effective. In addition, dedicated crops were not an option because the required plant size for an economic energy product was far in excess of typical power plant sizes. Lastly, there were no significant streams of forest thinnings, industrial byproducts, or mill residue.

Independent of project economics, Fort Sill is at the limit of its emission permit, and the presence of combustion-based renewable energy systems may require Fort Sill to apply for the next tier of emission permits. This is a challenging and complicated process that may only be justifiable with command support or economic motivation. Therefore, biomass projects would likely need to be considerably more attractive to overcome this issue. See Appendix B for more details.

\section{Wind Energy Findings and Recommendations}

Fort Sill has a moderately high wind energy potential, although the analysis shows that wind energy projects at Fort Sill would have poor economics given the current cost assumptions and should not be pursued on the basis of economics at this time. If capital costs decrease, more incentives become available, and/or utility rates increase, Fort Sill should reevaluate wind energy project economics. Alternatively, Fort Sill could consider pursuing a demonstration or energy security project because the site has many ideal characteristics for this type of development. 
With the site's wind resource and the current cost assumptions, the marginal electric rate would need to range between $13-57 \phi / \mathrm{kWh}$ to provide a $10 \%$ IRR, depending on the scale of the wind turbine considered. This is substantially more than the current electric rate at Fort Sill. Using ECIP funding, the SIR range from 0.0 to 0.99. These results are shown in Table 5.

Table 5: Economic Assessment of Wind Power

\begin{tabular}{|c|c|c|c|}
\hline Financing Scenario & \multicolumn{2}{|c|}{ ECIP } & IPP \\
\hline Economic Factor & SIR & Simple Payback, & Cost of Electricity at 10\% IRR \\
\hline Large Wind, 1.5-MW @ 1.36 $/ \mathbf{k W h}$ & negative & negative & 12.92 \\
\hline Large Wind, 1.5-MW @ 8.6c/kWh* & 0.99 & 14.4 & 12.92 \\
\hline Mid-Sized Wind, 100-kW & negative & negative & 26.07 \\
\hline Small Wind, 10-kW & 0.01 & 922 & 37.52 \\
\hline Building-Integrated Size, 2.4-kW & 0.0 & 1,342 & 57.28 \\
\hline
\end{tabular}

*With the typical capacity factor for a wind turbine at this location, it will likely produce more electricity than is purchased at 8.68.6 $\mathrm{k} / \mathrm{kWh}$. If so, lower cost electricity will need to be displaced, and the SIR will be lower.

Note that the project that resulted in a 0.99 SIR was for a $1.5-\mathrm{MW}$ turbine located at the range lands and assumes that nearly all the electricity consumed at the range lands is available to be displaced. However, the range buildings are sparsely situated primarily in the northern and western portion of the Fort. Moreover, the analysis used the blended electric rate across all meters, which was a necessary simplification given the nature of the analysis. If there is further interest in exploring large-scale wind development on the range lands, the analysis would require a more rigorous examination of the various electric tariffs (which would occur if a level 2 screening was performed). Evaluated against the range land cost of energy, the 1.5-MW turbine is nearly cost-effective given ECIP funding criteria. However, the range lands consume approximately $2.3 \mathrm{MWh}$ of electricity annually and the $1.5-\mathrm{MW}$ turbine can produce $3.9 \mathrm{MWh}$ annually. It is most likely that the excess energy produced on the range land would have to be wheeled to the cantonment area and would displace lower cost electricity. To accurately model this scenario, the energy wheeled back and consumed on-site would have to be evaluated against the cantonment area's marginal cost of energy rate. The cantonment area's low marginal cost of energy makes this split consumption scenario uneconomic.

A variety of small wind turbines were examined at Fort Sill's request. The small wind turbine cases had less economic potential because of the higher cost-per-kW capital costs and lower energy production of small systems. However, a small wind project on-site could be used as a demonstration or microgrid project.

This analysis is detailed in Appendix F. 


\section{Solar Energy Findings and Recommendations}

With current electricity prices and available solar resource, solar electricity did not prove economic. Fort Sill's solar resource was found to be 4.8 to $6.6 \mathrm{kWh}_{\text {solar }} / \mathrm{m}^{2} /$ day, depending on the technology. Ground-mounted fixed-angle photovoltaics (PV), axis-tracking PV, and building-integrated roof-mounted PV were too expensive for the amount of energy produced. Table 6 shows the detailed economic results for the ECIP funding and third-party financing analyses for the PV technologies. See Appendix E for analysis details.

Table 6: Economic Results for Solar Technologies

\begin{tabular}{||l|c|c|c|c||}
\hline Solar PV System & $\begin{array}{c}\text { Ground-Mounted } \\
\text { Fixed-Tilt PV }\end{array}$ & $\begin{array}{c}\text { Ground-Mounted } \\
\text { Axis-Tracking PV }\end{array}$ & $\begin{array}{c}\text { Roof-Mounted } \\
\text { CdTe PV }\end{array}$ & $\begin{array}{c}\text { Roof- } \\
\text { Mounted Si } \\
\text { PV }\end{array}$ \\
\hline $\begin{array}{l}\text { Equipment Cost Assumptions, } \\
\text { \$/kW }\end{array}$ & 5,625 & 6,625 & 4,000 & 4,500 \\
\hline SIR & 0.0 & 0.0 & 0.0 & 0.0 \\
\hline Simple Payback, yrs & $\mathrm{n} / \mathbf{a}^{*}$ & $\mathrm{n} / \mathrm{a}$ & $\mathrm{n} / \mathrm{a}$ & $\mathrm{n} / \mathrm{a}$ \\
\hline $\begin{array}{l}\text { Cost of Electricity at 10\% IRR, } \\
\text { c/kWh }\end{array}$ & 40.40 & 38.11 & 31.22 & 35.60 \\
\hline $\begin{array}{l}\text { Variable Operations and } \\
\text { Maintenance (O\&M), } \boldsymbol{c} / \mathbf{k} \mathbf{W h}\end{array}$ & 0.0 & 0.0 & 0.0 & 0.0 \\
\hline Fixed O\&M, \$/net kW & 20 & 33 & 20 & 20 \\
\hline $\begin{array}{l}\text { Federal Energy Tax Credit (a } \\
\text { credit worth a percentage of the } \\
\text { expenditures) }\end{array}$ & $30 \%$ & $30 \%$ & $30 \%$ & $30 \%$ \\
\hline $\begin{array}{l}\text { State Production Tax Credit, } \\
\text { c/kWh }\end{array}$ & 1.5 & 1.5 & 1.5 & 1.5 \\
\hline
\end{tabular}

$* \mathrm{n} / \mathrm{a}$ indicates the calculation resulted in an undeterminant (i.e., non-real) answer ,

Although the economics are unfavorable, there is interest at Fort Sill in solar demonstration projects and microgrid applications. Fort Sill should continue to monitor the market conditions affecting solar energy, the incentives available, and the installation's energy needs so a project can be reevaluated in the future if conditions change favorably.

\section{Waste-to-Energy Findings and Recommendations}

Although Fort Sill is currently unable to consider a WTE project because of emissions concerns, a handful of MSW scenarios showed somewhat favorable economics. A detailed economic analysis was conducted for four of the most likely cases so that Fort Sill will have this information available if the current situation changes. The results are shown in Table 7. 
Table 7: Waste-to-Energy Economic Results

\begin{tabular}{|c|c|c|c|c|}
\hline Waste Source & $\begin{array}{c}\text { Fort Sill and City } \\
\text { of Lawton } \\
\text { Landfill } \\
\end{array}$ & $\begin{array}{c}\text { Fort Sill and City } \\
\text { of Lawton } \\
\text { Landfill } \\
\end{array}$ & All Area Landfills & All Area Landfills \\
\hline Technology & Combustion & Gasification & Combustion & Gasification \\
\hline Plant Size & $23.3 \mathrm{MW}$ & $30.7 \mathrm{MW}$ & $44.5 \mathrm{MW}$ & $58.8 \mathrm{MW}$ \\
\hline Feedstock Amount & 211,104 tons/yr & 211,104 tons/yr & 403,585 tons/yr & 403,585 tons/yr \\
\hline Total Plant Cost & $\$ 3,236 / \mathrm{kW}$ & $\$ 3,832 / \mathrm{kW}$ & $\$ 2,842 / \mathrm{kW}$ & $\$ 3,366 / \mathrm{kW}$ \\
\hline Capital Cost & $\$ 2,972 / \mathrm{kW}$ & $\$ 3,520 / \mathrm{kW}$ & $\$ 2,611 / \mathrm{kW}$ & $\$ 3,092 / \mathrm{kW}$ \\
\hline Sales Tax & $\$ 264 / \mathrm{kW}$ & $\$ 312 / \mathrm{kW}$ & $\$ 232 / \mathrm{kW}$ & $\$ 274 / \mathrm{kW}$ \\
\hline Fixed O\&M Cost & $\$ 94 / \mathrm{kW}$ & $\$ 83 / \mathrm{kW}$ & $\$ 86 / \mathrm{kW}$ & $\$ 54 / \mathrm{kW}$ \\
\hline Variable O\&M Cost & $0.1 \notin / \mathrm{kWh}$ & $-0.2 \phi / \mathrm{kWh}$ & $0.1 \phi / \mathrm{kWh}$ & $-0.2 \phi / \mathrm{kWh}$ \\
\hline Feedstock Cost & $-\$ 9.27 /$ ton & $-\$ 9.27 /$ ton & $-\$ 9.27 /$ ton & $-\$ 9.27 /$ ton \\
\hline SIIR & 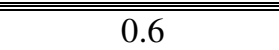 & 0.7 & 0.9 & (1.0 \\
\hline Simple Payback & 22.0 years & 19.3 years & 16.5 years & 14.8 years \\
\hline $\begin{array}{l}\text { Internal Rate of } \\
\text { Return (IRR), No } \\
\text { Financing }\end{array}$ & $3.21 \%$ & $2.98 \%$ & $5.17 \%$ & $5.62 \%$ \\
\hline
\end{tabular}

Two different technologies, gasification and combustion, were examined for this analysis. Gasification is more efficient than combustion, but not as mature or common in commercial operation as combustion. At Fort Sill, scenarios utilizing gasification were slightly more economical. Fortunately, gasification plants produce fewer emissions than combustion plants. The assumptions regarding the available waste and costs are critical to the economic results. If there are any changes to these assumptions, some options may become less attractive or possibly eliminated from consideration.

If the regulatory situation changes, Fort Sill should revisit these possible scenarios. Detailed data and results are provided in Appendix B.

\section{Geothermal Power Findings and Recommendations}

According to existing data, Fort Sill lacks naturally occurring hot water/steam fields and elevated temperatures at economic depths (less than 3,000 m). To reach the required temperature of at least $212^{\circ} \mathrm{F}\left(100^{\circ} \mathrm{C}\right)$, drilling to a depth in excess of $3,000 \mathrm{~m}$ is required, resulting in high drilling costs.

Because the geothermal resource is inadequate to support an economic project at Fort Sill, no immediate action should be taken. Considering the geology of the area in which Fort Sill is located, it is unlikely that there will be any changes in resource availability in the near future. Detailed data and results are provided in Appendix C.

\section{Shale Gas Findings and Recommendations}

Fort Sill personnel are aware of the shale gas potential in areas surrounding the site, and as a result, the site requested that PNNL perform a cursory review of existing literature to determine if there may be a practical shale gas resource. These resources indicate that Fort Sill is located within the Wichita uplift, a geologic sub-province of the Interior Plains of the Midwestern United States. The Anadarko Basin, which bounds the northern flank of the Wichita Mountains 
and contains a small portion of the northeast corner of Fort Sill, is a deep petroleum-rich basin that has been explored extensively across southwestern Oklahoma. A detailed map from Oklahoma Geological Survey of oil and gas fields located near Fort Sill shows that several oil, gas, and combined oil and gas fields are present near the eastern edge of the site. It is recommended that additional investigations into shale gas opportunities at Fort Sill utilize available well records and other published information for on-site and nearby oil and gas fields that could help identify the lithologic, structural and stratigraphic conditions of hydrocarbon rich source rocks beneath Fort Sill. Detailed data and results are provided in Appendix G. 
Pacific Northwest National Laboratory, March 2011 


\section{APPENDIX A}

\section{Business Case Analysis Approach}


Renewable Energy Opportunities at Fort Sill, Oklahoma

Pacific Northwest National Laboratory, March 2011 


\section{Appendix A: Business Case Analysis Approach}

\section{Overall Basis for Project Economic Feasibility}

The renewable projects considered in this analysis need to compare favorably against the current commercial price of electricity to be purchased by Fort Sill to be economically feasible. Fort Sill obtains its electricity from the Southwest Power Administration (SWAPA) via Public Service Company of Oklahoma (PSO) for the main cantonment area and Cotton Electric Cooperative (COOP) for various range land facilities. PSO also supplies supplemental energy when the SWAPA allocation is insufficient for the site's electricity needs. Between the three utilities, Fort Sill purchased 192,838 MWh for a cost of \$7.2 million dollars in fiscal year (FY) 2009 at an average rate of $\$ 0.037 / \mathrm{kWh}$.

SWAPA charges Fort Sill a base electric rate of $\$ 0.013$ per all kilowatt hour and an additional $\$ 0.0082 / \mathrm{kWh}$ for peaking and supplemental kilowatt-hours. There is a purchased power adder of $\$ 0.0067 / \mathrm{kWh}$ per peak kilowatt-hour. Demand charges were $\$ 3.51 / \mathrm{kW}$. Over FY 2009, the average blended rate for SWAPA was $\$ 0.026 / \mathrm{kWh}$. PSO charges Fort Sill a base rate of $\$ 0.036 / \mathrm{kWh}$, a fuel adjustment charge, which averaged $-\$ 0.002 / \mathrm{kWh}$ in FY 2009. Demand charges varied between $\$ 4.00$ to $\$ 4.45$ per $\mathrm{kW}$. A $70 \%$ ratchet is applied to the demand. In addition, each month has an individual peak demand charge of $\$ 0.60$ to $\$ 0.65$ per $\mathrm{kW}$. Over FY 2009 , the average blended rate for PSO was $\$ 0.054 / \mathrm{kWh}$. Several facilities located in Fort Sill's range lands are served by the Cotton Electric COOP. There are over a dozen meters served by the COOP and at various rates. During FY 2009, Fort Sill purchased 2,359 MWh from Cotton Electric COOP at an average rate of $\$ 0.086 / \mathrm{kWh}$.

Biomass, geothermal, and waste to energy power projects are capable of consistently and reliably delivering. As a result, these systems are able to displace both electricity and peak power charges, and therefore displace electricity at the blended rate value. Because the amount of energy needed from PSO varies from less than 1 megawatt-hour to over 10 megawatt-hours over the year, biomass, geothermal, and waste to energy renewable energy projects were assumed to displace both SWAPA and PSO derived electricity at an average blended rate of $\$ 0.037 / \mathrm{kWh}$.

Solar and wind renewable energy resources would displace the direct energy $(\mathrm{kWh})$ charge, or the marginal rate. These technologies cannot reliably reduce a site's peak demand and its related charges. Therefore, they cannot be assumed to displace electricity at the blended rate. Because these projects are sized to be approximately 1-MW in size, they are suitable to potentially displace the more expensive electricity from Cotton Electric COOP as both the wind and PV systems produce electricity on the order of the amount purchased from the COOP. PV and wind projects were evaluated using an electric rate of $\$ 0.086 / \mathrm{kWh}$.

All but one of the analyses was the Financial Analysis Tool for Electric Energy Projects (FATE2-P) financial analysis model, described later in this appendix. The analysis for GSHPs was conducted using the Federal Energy Decision System (FEDS) model, also described in this appendix. 


\section{Analytic Approaches}

In assessing the economic feasibility of renewable energy projects at Fort Sill, Pacific Northwest National Laboratory (PNNL) generally evaluated two business case alternatives, (1) investment by an independent power producer (IPP), and (2) Energy Conservation Investment Program (ECIP) funding. These two funding sources have the best returns on Federal investments among the available alternatives. Two other funding mechanisms were examined when evaluating GSHP projects: (3) the utility energy services contract (UESC), and (4) the energy savings performance contract (ESPC).

Under an IPP scenario, an independent power producer will generally fund, construct, and operate a renewable energy facility, selling power into the competitive marketplace and/or directly to the site that hosts the energy project. This scenario is generally economic when the third-party investor can take advantage of substantial Federal and state incentives. The incentives depend on the type of renewable energy generated and may include production tax credits, investment tax credits, substantially accelerated tax depreciation of assets, reductions in sales taxes, and exemption from property tax.

ECIP is one standard DoD approach for making energy efficiency and renewable energy investments using Federally appropriated funding. ECIP investment awards are made based upon savings to investment ratio (SIR) and simple payback criteria. ECIP funding is limited, and is awarded on a competitive basis within the Army-only the most economic projects can be assured funding. The approach used in the analyses follows the Federal life-cycle cost (LCC) methodology and procedures in 10 CFR, Part 436, Subpart A. The LCC calculations are based on the Federal Energy Management Program (FEMP) discount rates and energy price escalation rates updated on April 1, 2009.

The UESC and ESPC are similar approaches, where a third party invests in an energy project on the Federal facility in return for a share of the energy savings that result. The major difference is that under an UESC, the third party is a utility - generally the utility providing energy to the Federal facility. Under an ESPC, the investment party is a non-utility, generally an engineering firm that specializes in energy projects. Under UESC and ESPC, the third party must be repaid out of each year's operational dollars, and the investment must be repaid within the lifetime of the asset. Generally, UESC is more feasible than ESPC because utilities can obtain capital less expensively than can the ESPC contractor. But not all utilities fund UESC projects and the types of projects funded may be limited, opening the door for ESPC. The UESC/ESPC cannot generally capture depreciation or tax incentives that would be afforded an IPP.

\section{Independent Power Producer Assumptions}

In addition to capital and operating costs, project feasibility for the IPP is dependent on Federal and state tax incentives, interest rates, inflation rates, and required rates of return discussed in the following sections. 


\section{Federal Incentives for Renewable Energy}

Federal incentives for renewable energy include investment tax credits for corporations, significantly accelerated depreciation of equipment, and production tax credits. Combining the incentives with attractive market prices can lead to feasible renewable energy projects.

\section{Tax Credits}

A $30 \%$ business energy tax credit (investment tax credit) is available for photovoltaic and smallscale wind projects; a $10 \%$ credit is available for geothermal and biomass electricity projects (DSIRE 2010a). Large-scale wind, geothermal and biomass electricity generation projects also qualify for production tax credits (JCT 2007), but both cannot be taken at the same time.

Financial crisis emergency legislation lengthened the investment tax credit period by 8 years to January 1, 2017 from its previous end of December 31, 2008 (H.R. 1424 2008). There are no incentive limits for solar and geothermal electric.

\section{Depreciation}

Most renewable energy equipment qualifies for significantly accelerated depreciation using the modified accelerated cost recovery system (MACRS). According to 168(e)(3)(B)(vi), most renewable energy production facilities would qualify for 5-year accelerated depreciation (U.S. Treasury 2009a).

Table A-1 provides the depreciation rates used in the model for 5-year property. The rates reflect the use of the 3/4-year convention. The basis is reduced by $50 \%$ of any energy investment tax taken (JCT 2007). The tax basis for depreciation must also be reduced by the amount of any Federal subsidy used in the financing of the eligible equipment (26 USC $\S 48$ ).

Table A-1: MACRS Depreciation Rates for Renewable Energy Projects

\begin{tabular}{||c|c|c|c|c|c|}
\hline Year 1 & Year 2 & Year 3 & Year 4 & Year 5 & Year 6 \\
\hline $35 \%$ & $26 \%$ & $15.6 \%$ & $11.01 \%$ & $11.01 \%$ & $1.38 \%$ \\
\hline
\end{tabular}

\section{Production Tax Credits}

The renewable energy production tax credit (PTC) provides a per-kWh-produced tax credit for electricity generated. The PTC has been allowed to lapse and then been renewed several times. Currently the PTC is $2.1 \phi / \mathrm{kWh}$ in 2009 for wind, geothermal, and closed-loop biomass (biomass that is grown with the sole purpose of being used to generate energy) and can be taken for 10 years. The PTC is $1.1 \phi / \mathrm{kWh}$ for electricity produced from open-loop biomass and municipal solid waste resources and can be taken for 5 years (U.S. Treasury 2009b). The PTC for solar electricity generation has been excluded for equipment placed in service after December 2005 (H.R. 6111 2006). All of the analyses assume it will be available when the equipment is placed in service.

\section{Oklahoma-Specific Incentives and Taxes}

Oklahoma has few incentives for commercial renewable production facilities. Oklahoma provides a production tax credit for solar photovoltaic and wind electricity production. The production tax credit is $\$ 0.005 / \mathrm{kWh}$ for 10 years. There appears to be no limits (DSIRE 2010b). 
The Oklahoma income tax is $6 \%$ (OTC 2010). The sales tax is $8.75 \%$. The sales tax is composed of the state $(4.5 \%)$, county $(0.25 \%)$ and city $(4.125 \%)$ rates combined (OTC 2009). Property tax rates for Comanche County Oklahoma run between $\$ 70$ and $\$ 1,130$ per $\$ 1,000$ dollars of assessed value based on how many jurisdictions apply to the private energy facility. The City of Lawton rate is $\$ 80.55$ per $\$ 1,000$. This analysis assumed that the effective rate for facilities on the Fort's premises would be $2.8193 \%$. Oklahoma assesses personal property at $35 \%$ of fair market value. Half of property tax rate was used because Oklahoma uses a declining balance for the value of personal property (CCO 2009, CCO.com 2009).

Oklahoma does have Renewable Energy Goal that requires $15 \%$ of installed generation capacity be from renewable energy resources by 2015. However, the goal does not extend beyond 2015 and energy efficiency can be used to one-quarter of the goal. Oklahoma's law does not require utilities to purchase and retire renewable energy credits (REC) thus the potential for state generated RECs does not exist (DSIRE 2010c).

\section{Other Independent Power Producer Assumptions}

The minimum after-tax internal rate of return (IRR) used in the analysis of IPP opportunities was $10 \%$. The typical after-tax rate of return for most third-party developers is closer to $15 \%$, but there appears to be a suite of renewable energy developers willing to accept a lower return. Both costs and prices were assumed to escalate with an inflation rate of $1.2 \%$.

\section{Energy Conservation Investment Projects}

The assumptions for ECIP are driven by FEMP. Table A-2 lays out the discount rates underlying the model as of April 2009. The real and nominal rates for DOE/FEMP imply a $1.2 \%$ inflation rate. New discount rates were obtained from Rushing and Lippiatt (2009).

Table A-2: Discount Rate Assumptions in the ECIP Model

\begin{tabular}{|r|c|c|c|c|c|c||}
\hline \hline Discount Rate & $\begin{array}{c}\text { DOE } \\
\text { FEMP }\end{array}$ & $\begin{array}{c}\text { OMB 3- } \\
\text { year }\end{array}$ & $\begin{array}{c}\text { OMB 5- } \\
\text { year }\end{array}$ & $\begin{array}{c}\text { OMB 7- } \\
\text { year }\end{array}$ & $\begin{array}{c}\text { OMB 10- } \\
\text { year }\end{array}$ & $\begin{array}{c}\text { OMB 30- } \\
\text { year }\end{array}$ \\
\hline real & $3.0 \%$ & $2.1 \%$ & $2.3 \%$ & $2.4 \%$ & $2.6 \%$ & $2.8 \%$ \\
\hline nominal & $4.2 \%$ & $3.3 \%$ & $3.5 \%$ & $3.6 \%$ & $3.8 \%$ & $4.0 \%$ \\
\hline
\end{tabular}

\section{FATE2-P Model Description}

The FATE2-P (Financial Analysis Tool for Electric Energy Projects) financial analysis model was used to evaluate the feasibility of renewable energy projects at Fort Sill. The spreadsheet model was developed by Princeton Economic Research, Inc. and the National Renewable Energy Laboratory for the U.S. Department of Energy. FATE2-P can be used to develop pro forma financial statements for a utility using a revenue requirements approach or an IPP using the discounted rate of return approach. Both approaches are diagrammed in Figure A-1. Other models produce very similar results given the same inputs. The revenue requirements approach follows a cost-based utility revenue requirements analysis, and the IPP approach uses a marketbased discounted cash flow return. The FATE2-P model has been updated by PNNL to include the Military Construction (MILCON) ECIP Module in addition to the rate of return methodology. The model has been used to model improved technology designs, resource variability, and favorable tax treatment on renewable energy products. The advantage this model 
has over other models is that it is already suited for handling all of the renewable energy technologies in this study through one model, thus providing results on a comparable basis across all technologies.
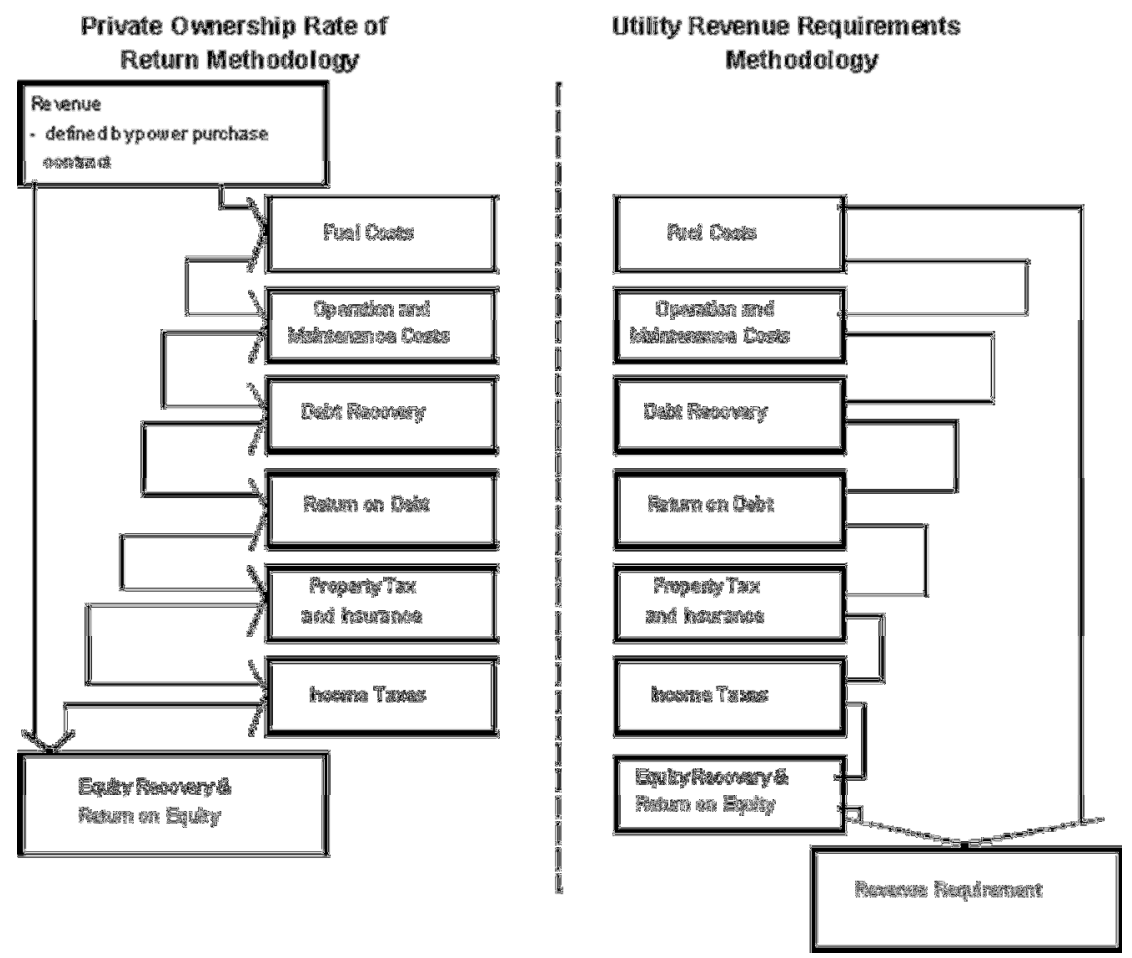

Figure A-1: FATE2-P Methodology

\section{Private Ownership Rate of Return Methodology}

The Private Ownership Rate of Return Module (IPP) develops an annual after-tax cash flow based on the revenues defined in the power purchase contract and costs associated with constructing and operating the generation facility. The goal of this approach is to capture the relevant investment costs after-tax and compare them with the net cash flow from the after-tax investment over time. The model contains sections to capture the relevant costs of construction, including the debt and equity capital accumulation to purchase the investment and the associated payback of debt and equity capital. In addition, the model has sections associated with revenue generation, cash flow, an income statement, and associated statements to calculate tax liabilities to capture after-tax cash flow. The financing section includes several pertinent sections including sources and uses, construction and debt accumulation, reserve funds requirements, debt schedule, amortization of debt fees, and debt service coverage ratios.

- The Sources and Uses of Funds section shows the allocation of construction funds between components and sources of those funds. Uses of funds include construction cost, AFUDC (allowances for funds used during construction), and underwriters' fees for both debt and equity.

- The construction and debt accumulation statement is capable of handling a 6-year construction period starting at any date. Any construction draw schedule can be used for 
1 to 6 years. An equal percentage draw schedule for each year of any given construction length is the default.

- The model contains major maintenance and debt-service reserve funds. Both types of accounts generate interest income that becomes a part of the income statement through a drawn-off interest calculation. The model does not currently calculate a working capital reserve account. Such an account would add interest costs to the cost statement in addition to the interest costs on the capital investment.

- The debt schedule allows three types of financing: level payment, bullet, and customized. Level payment is customary for projects that have adequate cash flow to satisfy debt coverage payments and are of short duration. Customized is required when certain years fall below the minimums set by the investment banking industry.

- Cash flow statements can be constructed for up to 30 years of revenue generation plus the 6-year construction time frame.

- The revenue module contains a variable capacity factor that must be filled in by the analyst to capture depletion of the geothermal fields or the capacity of wind or the other renewable energy resources. This section also allows for secondary energy by-product credits (such as for steam if it has value), and up to six different types of subsidy payments, if available. The model also accepts after-tax production credits, if available, and includes interest on reserves.

- Cash expenses statements include standard operations and maintenance (O\&M) costs (both fixed and variable), general and administrative (G\&A), insurance, and land fees. There is major maintenance expense along with a reserve fund dedicated to covering the major maintenance when it occurs. Up to two different fuel costs can be entered. There is also an entry for royalty fees associated with geothermal.

- The earnings statement in this model calculates earnings and taxes based on a tax table. Operating income is calculated by subtracting cash and operating expenses from revenue, as described in the section above. Taxable income is determined by subtracting cash and non-cash expenses such as interest, depreciation, amortization of fees, IDC (interest during construction) and depletion allowances. Taxes paid and tax credits received are netted and after-tax book income is calculated. The net taxes paid become a part of the cash flow.

- The model includes straight-line and MACRS depreciation approaches, with mid-quarter convention depreciation tables. Straight-line allows for the calculation of book basis value of assets and liabilities, while MACRS allows for the taxable basis of the investment.

- The model amortizes debt-related fees over 15 years and equity organizational fees over 5 years. Equity tax advice is expensed in the first year, and equity broker fees are excluded.

- The model calculates depletion allowances on geothermal projects. The model also depletes certain AFUDC when appropriate.

- Income tax and other tax statements are prepared for Federal and state taxes paid as well as tax credits earned. Tax calculations include excise taxes, Federal, state and local taxes. 
Depreciation calculations used to capture after-tax cash flow can use either straight-line or MACRS. There is also a section to incorporate local property taxes and special tax assessments.

- The assumptions section is fairly extensive and covers construction costs, debt acquisition, equity acquisition, capacity factors, fixed and variable O\&M inputs, financial factors such as interest rates, G\&A expenses, real escalation in O\&M charges, unfired fuel assumptions, byproduct credits, asset life, inflation rates, tax rates, property tax rates, insurance, investment tax credits, AFUDC, local gross receipts tax, and special property tax assessments.

- Total plant cost (overnight) is divided into: sales tax; rotor, gearbox, generator; tower and civil work; controls, transformer, interconnect; design/engineering;

permitting/environmental, construction labor and supervision; contingency; home office overhead; real escalation in construction cost; miscellaneous depreciable cost (last year of construction); sales tax on miscellaneous depreciable cost; land cost; and startup cost.

\section{ECIP Module}

The FATE2-P model also includes a life-cycle cost module based on the Buildings Life-Cycle Cost (BLCC) model (produced by the National Institute of Standards and Technology) and a MILCON ECIP module, which in turn fills out Form 1391. The ECIP module currently reflects 2009 forecast discount and inflation rates. The ECIP module provides values for first-year savings, simple payback, total discounted operational savings, SIR, and adjusted IRR.

\section{The Facility Energy Decision System (FEDS) Model}

FEDS is a building energy modeling software developed by PNNL to support the economic analysis of efficiency technologies at large, multi-building sites. Building characteristics are entered into the model using as much detail as possible, and the model uses the given information to make inferences for the remaining characteristics. Multiple sets of building data can be entered into the same model, so that an entire site can be represented at once. The optimization cycle uses data about the location of the site and the energy prices entered into the model to determine cost-effective retrofits for each set of building data, and to calculate costs and savings. The suggested retrofits can range from lighting to building envelope to heating and cooling, covering all aspects of a building's energy use and considering interactive effects. In addition, the model can be adjusted to consider just one type of retrofit. In this analysis, GSHPs were the only technology analyzed using FEDS.

\section{Business Case Analysis Sources of Information}

Comanche County Oklahoma (CCO). 2009. "Comanche County, Oklahoma: 2009 Levies." Accessed on May 26, 2010 at

http://comanchecounty.us/main/index.php?option=com_docman\&task=cat_view\&gid=93\&Item $i d=18$ 
Comanchecountok.com (CCO.com). 2009 "Comanche County Assessor." Accessed on May 26, 2010 at

http://comanchecounty.us/main/index.php?option=com_docman\&task=cat_view\&gid=93\&Itemi $\underline{\mathrm{d}=18}$

DSIRE- Database of State Incentives for Renewables \& Efficiency. 2010a. Federal Incentive/Policies for Renewables and Efficiency: Business Energy Investment Tax Credit (ITC). Accessed April 23, 2010 at http://www.dsireusa.org/incentives/incentive.cfm?Incentive_Code=US02F\&re=1\&ee=1 (last update June 10, 2009).

DSIRE - Database of State Incentives for Renewables \& Efficiency. 2010b. Oklahoma: Incentives/Policies for Renewables \& Efficiency: Zero-Emission Facilities Production Tax Credit. Accessed May 26, 2010 at http://www.dsireusa.org/incentives/incentive.cfm?Incentive_Code=OK02F\&re=1\&ee=1 (last review July 27, 2010).

DSIRE - Database of State Incentives for Renewables \& Efficiency. 2010c. Oklahoma: Incentives/Policies for Renewables \& Efficiency: Renewable Energy Goal. Accessed May 26, 2010 at http://www.dsireusa.org/incentives/incentive.cfm?Incentive_Code=OK05R\&re=1\&ee=1 (last review June 1, 2010).

H.R. 1424. 2008. Emergency Economic Stabilization Act of 2008. Enrolled Bill. http://www.govtrack.us/congress/billtext.xpd?bill=h110-1424.

H.R. 6111. 2006. Tax Relief and Health Care Act of 2006 (Enrolled as Agreed to or Passed by Both House and Senate). Title II, Section 201. Summary available at http://www.govtrack.us/congress/bill.xpd?bill=h109-6111\&tab=summary.

JCT - Joint Committee on Taxation. 2007. Description of the Chairman's Modification to the Provisions of the "Heartland, Habitat, Harvest and Horticulture Act of 2007" (JCX-96-07). Available at http://www.jct.gov/publications.html?func=select\&id=19.

Oklahoma Tax Commission (OTC). 2010. "Chapter 50. Income: Tax rate for corporations." OAC 710:50-17-5.

Oklahoma Tax Commission (OTC). 2009. "Sales/Use/Lodging Tax Rate Charts: $4^{\text {th }}$ Quarter 2009 Download (as of November 1, 2009)." Accessed November 2009 at http://www.tax.ok.gov/ratechts.html.

Rushing, Amy S and Barbara C Lippiatt. 2009. Energy Price Indices and Discount Factors for Life-Cycle Cost Analysis - April 2009. NISTIR 85-3273-23 (Rev. 5/09). U.S. Department of Commerce, National Institute for Standards and Technology, Washington D.C. United States Code. "26 USC § 48. Title 26. Internal Revenue Code. Subtitle A - Income Taxes. Chapter 1 - Normal Taxes and Surtaxes. Subchapter A - Determination of Tax Liability. Part IV - Credits Against Tax. SubPart E - Rules for Computing Investment Credit. 
United States Code Service. 2006. "16 USC § 796 (2006). Title 16 - Conservation. Chapter 12-Federal Regulation and Development of Power. Subchapter 1 - Regulation of the Development of Water Power and Resources. Definitions. 2006.

United States Code Service. 2006. "26 USC § 168 (2006). Title 26. Internal Revenue Code. Subtitle A - Income Taxes. Chapter 1 - Normal Taxes and Surtaxes. Subchapter B Computation of Taxable Income. Part VI - Itemized Deductions for Individuals and Corporations.

U.S. Treasury - United States Department of the Treasury. 2009a. Publication 946: How to Depreciate Property. Internal Revenue Service. Washington, D.C. Accessed June 2010 at http://www.irs.gov/app/picklist/list/publicationsNoticesPdf.html (last updated April 26, 2010).

U.S. Treasury - United States Department of the Treasury. 2009b. Form 8835: Renewable Electricity, Refined Coal, and Indian Coal Production Credit. Internal Revenue Service. Washington, D.C. Accessed June 2010 at http://www.irs.gov/pub/irs-pdf/f8835.pdf (last updated 2009). 


\section{APPENDIX B}

\section{Analysis of Biomass and Waste-to-Energy Opportunities}


Renewable Energy Opportunities at Fort Sill, Oklahoma

Pacific Northwest National Laboratory, March 2011 


\section{Appendix B: Analysis of Biomass and Waste-to-Energy Opportunities}

\section{Biomass and Waste-to-Energy Technology}

The term "biomass" refers to renewable fuels used for power production that include agricultural waste, forest and wood processing waste, animal waste, industrial waste, dedicated biomass crops, and methane from landfills and wastewater treatment plants. Waste-to-energy (WTE) is similar, but includes municipal solid waste (MSW) and construction and demolition (C\&D) waste as fuel sources. These feedstocks qualify as renewable sources for Energy Policy Act of 1992 (EPAct) compliance purposes, but some states and alternative goals have different feedstock requirements. For instance, the current state of Oklahoma Renewables Portfolio Standard includes landfill gas, biomass, municipal solid waste (MSW), anaerobic digestion, and other renewable resources approved by the Oklahoma Corporation Commission (OCC) (DSIRE 2010). While biomass and WTE projects may be different in terms of their fuel sources, fuel collection modes, and fuel cost profiles, ultimately, the energy production often relies on similar technologies.

The primary technologies for producing electricity rely on steam turbines, gas turbines, or combined cycle turbine generators. Generators are energized by steam produced from direct combustion of raw material, or a synthetic gas (syngas) produced through anaerobic digestion or gasification. Direct combustion and anaerobic digestion technologies are mature and have been proven commercially. Gasification technologies are newer to the market, but are promising based on a number of successful installations. Anaerobic digestion is widely used but primarily for smaller applications in rural and municipal projects rather than large commercial installations.

Combustion systems burn biomass to produce steam in a boiler, turning a turbine connected to a generator. This method of producing electricity is quite inefficient, at about 20 to $30 \%$. In these systems, combustion products tend to form deposits on the heat transfer surfaces, increasing maintenance requirements and decreasing the lifetime of these surfaces as a result of corrosion and erosion. Ash has to be collected and removed from the system. The variability of incoming feedstock in terms of its composition and moisture content can present problems in combustion systems, most notably with MSW and mixed feeds. Systems that use a more homogeneous feedstock benefit from more complete combustion, which increases efficiency and reduces combustion waste products and emissions. Various boiler designs try to address these issues.

Gasification is more efficient than combustion, but the technologies employed are not as mature or common in commercial operation. The two basic types of gasification are direct-fired (aerobic) and indirect-fired (anaerobic). Gasification uses oxygen (direct-fired systems only), steam, heat, and pressure to break down organic materials to produce syngas, which is primarily hydrogen and carbon monoxide. Syngas is cleaned to remove impurities, then is used to generate electricity in a gas turbine or fuel cell, or is used to produce transportation fuels and/or commercially valuable chemicals. The syngas resulting from direct-fired systems has a lower heating value than the syngas from indirect-fired systems, and requires significant upgrading and processing to be used as fuel. The inorganic materials are discharged as inert solids that can often be used for another purpose. There are many types of gasification designs that use 
different amounts of oxygen and steam at different stages and temperatures, producing different amounts of waste heat, syngas, and solids.

Plasma melting is one gasification process just now entering the commercial market for use with MSW. Although it has a short track record, it is worth considering because of its positive attributes for use on a military facility. The plasma melter uses a plasma torch to decompose the material being gasified, resulting in a much higher temperature and more complete reaction.

This new technology produces only syngas from the organics, molten metal from any metals, and a hard glass-like substance from the inorganics. Gaseous emissions are released and scrubbed to remove pollutants, and the solid waste can be sold and used for other commercial purposes, such as construction material. Ash collected from syngas cleaning can be fed back into the plasma melter. Hazardous materials can also be gasified in this process, sealing the toxic substances into the solid waste with no potential for leaching (EvTEC 2002).

Digesters tend to be smaller systems and are typically used just for biomass. They are usually located at the biomass source, such as farms with significant amounts of animal manure and wastewater treatment facilities. Digesters break down biomass in warm, wet environments to produce methane, which can be captured as fuel for generating electricity. Aerobic digesters are common in developing countries for production of heating and cooking fuel in rural areas. Anaerobic digesters limit the amount of oxygen in the gasification process, producing gas with a higher concentration of methane, which is better for power production. Because of the smaller size of digester systems, electricity is typically generated using fuel cells, microturbines, or reciprocating engines.

Methane is also produced through anaerobic digestion in landfills as the garbage underground breaks down. Historically, it has been left in the ground, but the risk of fire and greenhouse gas emissions has led the Environmental Protection Agency (EPA) to require landfills to remove the methane. The methane could be used in an electricity generation system if the project economics are positive. The most economic opportunities for landfill methane capture and use are in cases where the landfill already has a collection system in place, is active or recently closed (methane production tapers off as landfills age), and has sufficient waste (typically at least 1 million tons) to generate a significant amount of methane. The landfill must be lined as well, to prevent water intrusion into the landfill that stifles digestion of the waste and methane production and to prevent the methane from migrating into the surrounding soil. New landfills are typically lined by regulation; many older ones are not. Methane production even from large landfills is relatively low; as a result, power facilities that use it are typically small systems located on-site using fuel cells, microturbines, or reciprocating engines.

For all of these technologies, except landfill gas, a power plant will require feedstock storage space, feedstock preparation equipment, feed equipment, processing equipment, product cleaning and collection equipment, electricity generation equipment, ash and waste storage space, water for steam and cooling, and emissions control equipment. The specific infrastructure and space required for each of these depends on the type of feedstock and process used the amount of feedstock used, and existing site conditions. As an example, one plasma gasification project evaluated could process 250 tons of MSW per day in an 80-foot by 175-foot area, not including storage space. However, permanent systems with infrastructure typically need up to 5 acres. 
Some feedstocks require year-round storage, because they are only available seasonally (e.g., crop residue); some feedstocks are available almost continuously and require less storage space (e.g., MSW). A feedstock available continuously may need about 20 days of fuel stored in case of supply interruption, which can use about 40 acres of land, depending on the overall size of the plant. Most plants only store 3 to 5 days of fuel on-site, requiring about 4 to 5 acres. Feedstocks available only once or twice a year will need hundreds of acres of land. Some feedstocks can be compressed into uniform-sized pellets, to simplify storage, transport, and combustion. However, the pelletization can add $20 \%$ to fuel costs. Storage areas may have to be located some distance away from the plant because of site constraints. However, nearby storage is preferred to reduce operational costs.

Emissions control requirements depend upon the process used and on regulations affecting the site. Some gasification processes (with gas scrubbers) produce no criteria pollutants, such as $\mathrm{SO}_{\mathrm{X}}$ and $\mathrm{NO}_{\mathrm{X}}$. However, air emissions are inevitable if the resulting syngas is burned in a conventional power generator. Emissions are a primary concern on the Louisiana side of Fort Sill, as the region is at or near a non-attainment status, and will soon be required to develop plans to improve air quality.

The capital cost of biomass plants ranges from about $\$ 1,500$ to $\$ 7,000 / \mathrm{kW}$, depending upon scale and specific technologies used (Aabakken 2006). Smaller projects cost much more, resulting in higher energy costs, while larger project cost less per $\mathrm{kW}$, resulting in more affordable energy costs. Direct combustion technologies tend to be both larger and less capitalintensive than those based on syngas. Digesters tend to have a higher unit cost, primarily because of their smaller size. Operation and maintenance (O\&M) for digesters is also more expensive, costing about $2.0 \notin / \mathrm{kWh}$, compared to about $1.0 \phi / \mathrm{kWh}$ for combustion plants (Aabakken 2006). The advantage for digesters is the low cost of fuel, which is typically free local waste (e.g., sewage sludge, manure).

Even a "free" feedstock such as crop wastes, which is not currently collected nor located at one site, does not guarantee a successful project, because collection, transportation, and storage costs can be, and often are, economically prohibitive. The economics of MSW projects are typically more attractive than other biomass projects because fuel is often delivered free or even accompanied by payment in the form of a tipping fee. Most landfills are operated or franchised by a local government. Many of these derive operating revenues from fees that are added to the actual operating costs of the landfill. As a result, the tipping fee may be inflated over actual costs and therefore not an accurate representation of costs that can be avoided.

\section{Siting Considerations}

For all of these technologies, except landfill gas, a power plant will require feedstock storage space, feedstock preparation equipment, feed equipment, processing equipment, product cleaning and collection equipment, electricity generation equipment, ash and waste storage space, water for steam and cooling, and emissions control equipment. The specific infrastructure and space required for each of these depends on the type of feedstock and process application, the amount of feedstock used, and existing site conditions. Permanent systems with infrastructure typically need up to 5 acres (excluding feedstock storage). 
Some feedstocks require year-round storage, because they are only available seasonally (e.g., crop residue); some feedstocks are available almost continuously and require less storage space (e.g., MSW). A feedstock available continuously may need about 20 days of fuel stored in case of supply interruption, which can use about 40 acres of land, depending on the overall size of the plant. Most plants only store 3 to 5 days of fuel on-site, requiring about 4 to 5 acres. Feedstocks available only once or twice a year will need hundreds of acres of land for storage. Some feedstocks can be compressed into uniform-sized pellets to simplify storage, transport, and combustion. However, the pelletization can add $20 \%$ to fuel costs. Storage areas may have to be located some distance away from the plant because of site constraints, but nearby storage is preferred to reduce operational costs.

\section{Biomass and Waste-to-Energy Analysis Approach}

The critical factor in determining feasibility for biomass energy generation is feedstock availability. There are a number of potential feedstocks that were evaluated for use at Fort Sill. The following questions were asked about each feedstock:

- Does this material exist in the surrounding region within 60 miles? (The maximum economic transport distance is assumed to be 30 to 60 miles.)

- How much is available within this area, on average? Is availability constant or variable, depending on crop rotation cycles and/or market conditions?

- How much is available for use as a feedstock? Availability is based on the feedstock being able to be collected and the lack of competing uses or markets. For example, wheat straw is typically left in the field to protect and rebuild the soil. If it is collected, the resulting bales may have higher value as animal bedding than as fuel, creating a competing market for what was otherwise a waste material on the ground.

- How much electricity can be produced from the available biomass? This is a function of the quantity of material available, moisture content, and its relative heat value.

In this analysis, if the power potential available from a feedstock were less than 1-MW, it was not considered a feasible resource. The narrowed list of possible feedstocks was then evaluated on a simple economic basis. Feedstock costs were estimated based on tipping fees, collection costs, transportation costs, current market rates, and other relevant information. Other operational costs and construction costs were estimated by scaling existing plant data for the three primary technology types. Based on the amount of feedstock available and the size of plant required, a levelized cost of electricity was estimated for each.

For any options that are reasonably close to being cost-effective, further economic analysis was completed, including evaluating tax credits, other incentives, different financing options, and ranges of feedstock sources and amounts. Fort Sill's blended electricity cost of $3.7 \varnothing / \mathrm{kWh}$ was used for this economic analysis.

Any risks or potential issues associated with these remaining options were noted, to present all considerations surrounding an implementation decision. When possible, these were quantified. 
PNNL staff created a new tool that supports analyses of various plant sizes, costs, and fuel sources in a generic manner. This facilitates "what if" analyses where critical information about fuel source and cost is unavailable. The result is an estimate of what power from a project would cost using available data and staff assessments for missing data. It also allows staff to reverse engineer an answer using Fort Sill's power cost as a given. Specifically, the tool can be set up to provide an estimate of what size plant and fuel cost is needed to produce power for less than the current and projected future power rate. Data from a 2003 National Renewable Energy Laboratory (Bain et al. 2003) study of biomass fuels was used to initiate the analytic tool. The 2003 study costs were converted into 2009 dollars and scaled according to varying plant sizes following the methodology used in the study. Any size plant can be evaluated and any value can be varied to test for financial feasibility. The tool was only used for preliminary screening, as it does not adequately address taxes, incentives, or other factors. These economic factors have a significant impact on project feasibility, especially if it is assumed the power project will not be owned and operated by the government.

If the analysis resulted in highly uneconomic estimated costs, the option was rejected. For any options that appeared to be reasonably close to cost-effective in the screening tool, further economic analysis was completed, including evaluating tax credits, other incentives, different financing options, and ranges of feedstock sources and amounts. Any risks or potential issues associated with these remaining project options were noted, to present all considerations surrounding an implementation decision. When possible, these were quantified.

\section{Biomass and Waste Resource Characterization}

The following biomass and waste types were assessed for potential as feedstocks.

- Agricultural (crop residues, animal waste, dedicated biomass crops)

- Forest (thinnings, logging slash)

- Industrial (mill residue, other industry waste)

- Waste (MSW, landfill gas, biogas or biosolids from wastewater treatment plants)

\section{Agricultural Biomass}

The USDA has a database of agricultural production information by county and state. Information was gathered here about crop and livestock production.

\section{Crop Residue}

Crop residues are the plant remains in the field after harvest. Some crops have more residues than others do; some, like hay, have no residues at all because the entire plant is harvested. A certain amount of residue left on the soil minimizes erosion and maintains nutrients in the soil, and can provide habitats for game animals. However, too much residue can inhibit growth of a new crop. Depending on tilling practices, climate, crop type, soil type, and slope of the land, residue may or may not be available for removal. In general, conventional till practices need more residue than no-till practices; warm wet climates need more residue than cold dry climates; corn fields need more residue than wheat fields; coarse, well-drained soils need more residue than poorly-drained, heavy clay soils; and steeper slopes need more residue than flat land. In 
addition, crop residue availability is dependent on competing uses, like cattle feed, and seasonal yields, which can change dramatically from year to year.

In 2008, the major crops harvested within 60 miles of Fort Sill that left residues were wheat and sorghum (NASS 2010). See Table B-1 for the number of bushels and amount of residue produced on an annual basis. Available residue for biomass energy generation will be somewhere between these values and zero. A rule of thumb is that about $30 \%$ of the residues can be collected. However, these numbers will have to be verified on a farm-by-farm basis for a more accurate analysis.

Table B-1: Crops and Biomass Production near Fort Sill

\begin{tabular}{|l|c|r|r|r|}
\hline \hline & $\begin{array}{c}\text { Bushels } \\
\text { Produced }\end{array}$ & \multicolumn{1}{c|}{$\begin{array}{c}\text { Tons Residue } \\
\text { Remaining }\end{array}$} & \multicolumn{1}{c|}{$\begin{array}{c}\text { Tons Collectable } \\
\text { Residue }\end{array}$} & \multicolumn{1}{c|}{$\begin{array}{c}\text { Potential Electricity } \\
\text { Generation }\end{array}$} \\
\hline Wheat & $9,990,000$ & 509,964 & 152,989 & $18.4 \mathrm{MW}$ \\
\hline Sorghum & 264,500 & 6,613 & 1,984 & $0.2 \mathrm{MW}$ \\
\hline Total & $\mathbf{1 0 , 2 5 4 , 5 0 0}$ & $\mathbf{5 1 6 , 5 7 7}$ & $\mathbf{1 5 4 , 9 7 3}$ & $\mathbf{1 8 . 6}$ MW \\
\hline
\end{tabular}

It would cost about $\$ 10 /$ ton to transport the residues to the plant, and about $\$ 10 /$ ton for the farmer's collection effort. Therefore, crop residue feedstock cost is about $\$ 20 /$ ton. Using all crops together to gain the most benefit from economy of scale, the most cost-effective biomass option would be a gasification plant that could produce electricity at $11.09 \phi / \mathrm{kWh}$. This is more expensive than Sill's rate, and is not an economic option at this time.

Furthermore, crop residue may not be a reliable energy resource because of varying crop yields and alternative markets. Availability is dependent on seasonal yields, which can change dramatically with crop rotation, market conditions, and weather patterns. Availability is also dependent on competing uses, including livestock feed, which often pays almost \$42/ton for corn stover and over $\$ 21 /$ ton for wheat straw (Gallagher 2003), and may be located closer to the source. Therefore, it is not recommended to pursue wheat and sorghum crop residues at this time.

\section{Animal Waste}

Manure from cattle, swine, and poultry farms is generally reclaimed from animal housing and feeding areas and used as fertilizer for crops. This has become a problem because of overapplication. Bad odors and groundwater contamination are forcing farmers to find other ways to dispose of manure. Furthermore, greenhouse gas emissions are now more strictly regulated, so emissions from manure must be controlled. Anaerobic digestion technologies can turn wet manure into energy, and often can be used with existing collection and treatment systems. Poultry waste can be used directly in combustion or gasification systems because it has lower moisture content than cow or swine manure.

According to the National Agricultural Statistics Service, through the USDA, in 2009, there were no known swine or poultry farms in the area. All of the cattle reported were either beef cattle or pastured (NASS 2010). In general, it is safe to assume all beef cattle are pastured as well. Manure in pastures is not good feedstock material because it is not typically collected (increasing the costs and decreasing the heating value as it dries in the field). Only the manure from cattle on a feedlot can be assumed to be available for electricity generation. Therefore, using animal waste as a feedstock for electricity generation is not an option at this time. 


\section{Dedicated Crops}

The most common dedicated energy crops include switchgrass, hybrid poplar, willow coppice, and other short rotation woody crops (SRWC). Energy crops are fast-growing plants that can be harvested for use as energy in various forms. Switchgrass is a native prairie grass that grows best in warm dry climates like the Midwest. SRWC need lots of water and do well in colder climates like the Northeast. Specifically, they need at least 16 inches of rainfall per year, or need to be located on a body of water. Using dedicated crops as biomass is an option, but they are not always a readily available resource. Rather, agricultural land where the crops can be grown is the resource to be evaluated, and the feedstock cost would be based on the cost to farm that land, harvest the resource, and deliver it to the generation plant on post.

Switchgrass and hybrid popular are the most likely energy crops that would grow well near Fort Sill. According to De La Torre Ugarte et al., the production costs of switchgrass in the Fort Sill region would range from $\$ 16.87 /$ ton to $\$ 29.44 /$ ton, with an average of $\$ 21.99 /$ ton. Hybrid poplar production would range from $\$ 29.49 /$ ton to $\$ 34.57 /$ ton, averaging $\$ 30.96 /$ ton. In order to use this material in a biomass plant on-site, a transportation cost of $\$ 10 /$ ton would be added to the production cost. In addition, compensation for the farmer would be required, unless Fort Sill produced the energy crops itself.

Switchgrass would be the most economic feedstock choice; at this price with no compensation, it would require a 142-GW gasification plant to generate cost-effective electricity (at $3.7 \varnothing / \mathrm{kWh}$ ). Because of the required plant size to reach breakeven electricity costs, dedicated energy crops are not a feasible biomass option.

\section{Forest Thinnings and Logging Slash}

Logging slash includes branches, stumps, and other material that is generated during logging practices but left behind because it is not useful to the loggers seeking large tree trunks. Once this slash is cut and left on the forest floor, it dries out, becoming good fuel for fires. It also can get in the way of machinery during replanting efforts. Sometimes it is gathered into small piles and burned in a controlled manner to reduce the risk of widespread forest fire, but this practice pollutes the air and may be restricted by air quality regulations. Instead, it can be collected and transported to a biomass facility where the emissions can be controlled and the wood waste can be used to generate energy.

According to the Forest Service, there are is no logging slash or wood waste in the region surrounding Fort Sill (2010), therefore cellulosic biomass is not an option.

\section{Industrial Biomass}

Industrial biomass includes mill residue, food processing waste, textile waste, or waste from other specialized operations. There are many types of mills that use wood to produce various products, including lumber, shake and shingle, pulp, veneer and plywood, log chips, and posts, poles, and pilings. These processes generate waste in the form of sawdust and wood pieces, which are useful materials. In fact, most mill residue is currently used for fiber, fuel, or other uses. 
According to the Forest Service, there are is no mill residue, or mill by-products in the region surrounding Fort Sill (2010), therefore industrial biomass is not an option.

\section{Waste Biomass \\ Municipal Solid and Urban Wood Waste}

MSW and C\&D waste are being generated at greater rates each year while landfills are becoming full, resulting in greater hauling distances and increasing prices for waste disposal. Recycling is one way to reduce the strain on landfills; using the waste to generate energy is another. Some recyclables, like metals, must be separated out before waste is used for energy generation. All carbon-based materials, however, can be used to generate energy.

Fort Sill produces approximately 10,603 tons of MSW per year. Within 60 miles of Fort Sill, there are operating landfills in Lawton, Ninnekah, and Altus, Oklahoma. Waste disposed in this area totals about 403,585 tons per year, and is expected to remain about the same in the future. These landfills are summarized, with their respective tipping fees, in Table B-2.

Table B-2: Waste near Fort Sill

\begin{tabular}{|c|c|c|c|c|c|c|}
\hline Site & $\begin{array}{l}\text { Collection } \\
\text { Location }\end{array}$ & $\begin{array}{c}\text { Miles } \\
\text { from Sill }\end{array}$ & $\begin{array}{l}\text { Tipping } \\
\text { Fee }(\$)\end{array}$ & $\begin{array}{c}\text { Assumed } \\
\text { Cost } \\
\text { Savings (\$) }\end{array}$ & $\begin{array}{c}\text { Available } \\
\text { MSW } \\
\text { (tons/year) } \dagger\end{array}$ & $\begin{array}{c}\text { Potential } \\
\text { Electricity } \\
\text { Generation } \\
(\mathrm{MW})^{* *} \\
\end{array}$ \\
\hline Fort Sill & Fort Sill, OK & 0 & $\$ 0.00$ & $\$ 0.00$ & 10,603 & 1.5 \\
\hline $\begin{array}{l}\text { City of Lawton } \\
\text { Landfill }\end{array}$ & Lawton, OK & 16 & $\$ 18.53 *$ & $\$ 9.27$ & 200,501 & 29.0 \\
\hline $\begin{array}{l}\text { Southern Plains } \\
\text { Landfill }\end{array}$ & $\begin{array}{l}\text { Ninnekah, } \\
\text { OK }\end{array}$ & 34 & $\$ 18.53 *$ & $\$ 9.27$ & 158,463 & 22.9 \\
\hline City of Altus Landfill & Altus, OK & 43 & $\$ 18.53 *$ & $\$ 9.27$ & 34,018 & 4.9 \\
\hline \multicolumn{5}{|c|}{$\begin{array}{ll} & \text { TOTAL }\end{array}$} & 403,585 & 58.3 \\
\hline
\end{tabular}

The assumed cost savings for each site is discounted 50\% from the tipping fee, to account for any additional transportation needs and incentives to deliver waste to a new location. The tipping fees fund recycling programs and other waste management operations, so the city or county would want to retain a portion of the revenue to continue operating these programs. Fort Sill's waste and all waste in the area were evaluated as potential sources of feedstock. Depending on contracts, plans, capacity needs, and economic issues at each landfill or transfer station, none or all waste may actually be available. If these evaluated options are not feasible, other sources should be considered. Each landfill's waste could be an option for use as feedstock, either separately or in combination with other sources, including combinations of partial waste from more than one location.

Commercial C\&D waste is often primarily comprised of concrete, asphalt, or other materials that do not break down easily, thus it is typically not available for energy generation. The amount of available C\&D waste is unknown at this time for the region surrounding Fort Sill, but it is known Fort Sill has a C\&D landfill that received 12,517 tons of waste in 2009 (DEQ 2009). These 
materials often require separation in woody and non-woody materials to be used in a WTE facility, adding capital costs for the separation equipment. If a WTE project is pursued in the future, C\&D waste should be re-evaluated as a feedstock, keeping in mind that there will be additional costs associated with separating the waste.

The technologies considered for waste conversion include combustion and gasification, and some options were found to be cost-effective in the screening analysis. Fort Sill indicated any type of incineration project would require a modification of the existing emissions permit; therefore, a combustion-type project is of no interest at present. The site currently has a "synthetic minor" emission permit, and any type of incineration project would require a full title 5 permit. The potential electricity figures displayed in Table B-2 illustrate gasification technology capabilities. The Findings section below illustrates detailed economics for both technologies with understanding that a combustion-type plant is not currently a consideration.

\section{Landfill Gas}

Methane generated from decomposing waste is a combustible pollutant that must be controlled. It is typically vented or collected and flared to avoid buildup and danger of explosion. New greenhouse gas regulations are expected to require collection of landfill methane. Collected methane can be used as a fuel to generate heat or electricity.

For a worthwhile landfill gas project, the landfill should have at least 1 million tons in place, be at least 30 feet deep, receive at least 25 inches of rain annually, and be lined. Oklahoma receives 36.55 inches of precipitation annually based on state climatology data from the National Oceanic and Atmospheric Administration (2000).

Fort Sill has one operating landfill that is currently being assessed by the United States Department of Energy (DOE) for a landfill gas study. The study is slated to be completed in the fall of 2010, but preliminary results are not promising. No infrastructure currently exists, and the preliminary findings estimate generation capabilities on the order of $0.75-\mathrm{MW}$. No further specifics were provided, so the landfill capacity was calculated using data from the Oklahoma Department of Environmental Quality (2009), which provides annual numbers from 2000 to 2009. The average for this time period was applied back to the estimated landfill opening date of 1987 (USACE 2010), yielding an approximate waste-in-place of about 510,000 tons. Assessing this volume of waste, an LFG-to-electricity project would produce about $0.8-\mathrm{MW}$ at more than $6 \notin / \mathrm{kWh}$, which is not economic. Rate changes or increased incentives may make this more attractive in the future.

Landfill gas production drops off when no more waste is being added to the landfill. Therefore, it is not worthwhile to build a collection system and generation plant if waste will be used in a WTE plant instead of being deposited in the landfill. The findings section shows the economic analysis results of sending all available MSW to a WTE plant. If the DOE landfill gas study shows promise for using LFG to generate electricity or as a replacement for natural gas, site MSW should be removed from consideration of feedstock resources for a WTE plant.

Wastewater Treatment Plant Sludge

Wastewater treatment plant (WWTP) sludge is what remains after wastewater is treated and the clean water is returned to the ground or other body of water. It has high energy content when 
dried, but the drying process is energy-intensive and necessary before transportation. Sludge is similar in substance to manure; it is a very watered-down substance that is best processed on-site, where methane is generated with anaerobic digestion. Therefore, only on-site sources of sludge are reasonable to use for energy generation.

American Water owns and operates the WWTP at Fort Sill; however, the plant does not pay the utilities associated with operating the facility. The site is considering addition of 1 to 2-MW natural gas generators to provide backup power and demand management.

The sludge from the plant could be used to as an energy resource. To produce 1-MW of power, the annual production of sludge needs to exceed 13,400 tons. Sludge treated in an anaerobic digester becomes cost-effective (with a liberal assumption of no cost for the feedstock) at about $20 \mathrm{MW}$, which would require over 260,000 tons of sludge per year. Considering the WWTP produces 1,000 tons of sludge per year, Fort Sill is nowhere near this sludge requirement. Furthermore, because the sludge from the lagoons is not collected on a regular basis, it would not be possible to guarantee a consistent feedstock source. Therefore, WWTP sludge is not a feasible resource.

\section{Biomass and Waste-to-Energy: Economic and Other Analysis Parameters}

Data used in this analysis were obtained from local sources when possible, and the economic assumptions were generally conservative. The assumptions used are presented in the report. However, any significant changes to important assumptions may change outcomesopportunities that are just barely economic in this report may no longer be economic if the values are changed significantly.

Biomass and WTE options were analyzed using Energy Conservation Investment Program (ECIP) and independent power producer (IPP) funding scenarios. Cost-effectiveness for ECIP projects is determined with savings-to-investment ratio (SIR) values, and the internal rate of return (IRR) shows whether the IPP scenario is cost-effective. The economic assumptions used to analyze each scenario, including available incentives, are listed in Table B-3. The assumptions that vary per scenario are listed below with the results. The average cost of electricity that Fort Sill would pay for the renewable energy was assumed to be $3.7 \varnothing / \mathrm{kWh}$. 
Table B-3: Economic Assumptions, constant $\$ 2010$

\begin{tabular}{|c|c|}
\hline \multicolumn{2}{|l|}{ Economic Factors } \\
\hline Inflation & $1.2 \%$ \\
\hline Interest Rate & $10.0 \%$ \\
\hline Debt/Equity Ratio & N/A \\
\hline Real Discount Rate & $3.0 \%$ \\
\hline \multicolumn{2}{|l|}{ Tax Considerations } \\
\hline Federal Depreciation & MACRS \\
\hline Federal Tax Rate & $35 \%$ \\
\hline State Income Tax Rate & $6.0 \%$ \\
\hline State Sales Tax & $8.9 \%$ \\
\hline Property Tax Rate & $1.4 \%$ \\
\hline \multicolumn{2}{|l|}{ Incentives } \\
\hline Federal Production Tax Credit & $\$ 0.01 / \mathrm{kWh}$ \\
\hline State Production Tax Credit & $\$ 0.00 / \mathrm{kWh}$ \\
\hline Federal Energy Tax Credit & $0 \%$ \\
\hline State Energy Tax Credit & $0 \%$ \\
\hline Utility Rebate & $\$ 0 / \mathrm{kW}$ \\
\hline \multicolumn{2}{|l|}{ Technology } \\
\hline Plant Life* & 30 years \\
\hline $\begin{array}{l}\text { Capacity Factor (basis net kW output): Total } \\
\text { System** }\end{array}$ & $85 \%$ \\
\hline Real Escalation in Construction Cost & $0 \%$ \\
\hline Misc. Depreciable Cost (last year of construction) & $\$ 0$ \\
\hline Sales Tax on Misc. Depreciation Cost & $\$ 0$ \\
\hline Land Cost & $\$ 0 / \mathrm{kW}$ \\
\hline Startup Cost & $\$ 0 / \mathrm{kW}$ \\
\hline
\end{tabular}

\section{Findings: Biomass and Waste-to-Energy Opportunities}

The availability of animal waste, cellulosic biomass, mill residue, and other industrial waste are all inadequate to consider a large biomass generation project. Other potentially available biomass fuels including crop residues, dedicated energy crops, LFG, and WWTP sludge could not support economic electricity generation at this time.

\section{Municipal Solid Waste}

MSW is the best option for generating a significant amount of electricity at Fort Sill. Fort Sill's waste, combined with waste from the City of Lawton Landfill and all regional waste was evaluated for economic feasibility as WTE projects-each as a combustion or gasification 
project, though combustion technologies are likely not a consideration because of emissions concerns. Economics will depend on the availability and price of waste, and actual plant size, capital costs, and operating costs. The most cost-effective analyzed scenarios are presented in Tables B-4.

Table B-4: Site and Regional MSW Waste-to-Energy Results

\begin{tabular}{|l|c|c|c|c|}
\hline Waste Source & $\begin{array}{c}\text { Fort Sill and } \\
\text { City of Lawton } \\
\text { Landfill }\end{array}$ & $\begin{array}{c}\text { Fort Sill and } \\
\text { City of Lawton } \\
\text { Landfill }\end{array}$ & $\begin{array}{c}\text { All Area } \\
\text { Landfills }\end{array}$ & $\begin{array}{c}\text { All Area } \\
\text { Landfills }\end{array}$ \\
\hline \hline Technology & Combustion & Gasification & Combustion & Gasification \\
\hline Plant Size & $23.3 \mathrm{MW}$ & $30.7 \mathrm{MW}$ & $44.5 \mathrm{MW}$ & $58.8 \mathrm{MW}$ \\
\hline Feedstock Amount & 211,104 tons/yr & 211,104 tons $/ \mathrm{yr}$ & 403,585 tons/yr & 403,585 tons/yr \\
\hline Total Plant Cost & $\$ 3,236 / \mathrm{kW}$ & $\$ 3,832 / \mathrm{kW}$ & $\$ 2,842 / \mathrm{kW}$ & $\$ 3,366 / \mathrm{kW}$ \\
\hline \multicolumn{1}{|c|}{ Capital Cost } & $\$ 2,972 / \mathrm{kW}$ & $\$ 3,520 / \mathrm{kW}$ & $\$ 2,611 / \mathrm{kW}$ & $\$ 3,092 / \mathrm{kW}$ \\
\hline \multicolumn{1}{|c|}{ Sales Tax } & $\$ 264 / \mathrm{kW}$ & $\$ 312 / \mathrm{kW}$ & $\$ 232 / \mathrm{kW}$ & $\$ 274 / \mathrm{kW}$ \\
\hline Fixed O\&M Cost & $\$ 94 / \mathrm{kW}$ & $\$ 83 / \mathrm{kW}$ & $\$ 86 / \mathrm{kW}$ & $\$ 54 / \mathrm{kW}$ \\
\hline $\begin{array}{l}\text { Variable O\&M } \\
\text { Cost }\end{array}$ & $0.1 \phi / \mathrm{kWh}$ & $-0.2 \notin / \mathrm{kWh}$ & $0.1 \phi / \mathrm{kWh}$ & $-0.2 \notin / \mathrm{kWh}$ \\
\hline \multicolumn{1}{|c|}{ Feedstock Cost } & $-\$ 9.27 / \mathrm{ton}$ & $-\$ 9.27 / \mathrm{ton}$ & $-\$ 9.27 / \mathrm{ton}$ & $-\$ 9.27 / \mathrm{ton}$ \\
\hline \hline \hline SIR & 0.6 & 0.7 & 0.9 & 1.0 \\
\hline Simple Payback & 22.0 years & 19.3 years & 16.5 years & 14.8 years \\
\hline $\begin{array}{l}\text { Internal Rate of } \\
\text { Return }(I R R), ~ N o \\
\text { Financing }\end{array}$ & $3.21 \%$ & $2.98 \%$ & $5.17 \%$ & $5.62 \%$ \\
\hline \hline
\end{tabular}

These scenarios show combustion and gasification options are marginally economic at Fort Sill, with a gasification plant using all regional waste showing the most promise. Fortunately, gasification plants produce fewer emissions than combustion plants. The assumptions regarding the available waste and costs are critical to the economic results. If there are any changes to these assumptions, some options may become less attractive or possibly eliminated from consideration.

\section{Biomass and Waste-to-Energy: Next Steps}

Using MSW to generate electricity shows some merit for further investigation at Fort Sill. The following steps must occur to determine whether this resource is worth pursuing:

- Determine Fort Sill's level of interest in a WTE project located on or near the base.

- Determine the interest level of the local waste management firms in cooperating with the Army on a WTE project. 
- Quantify the amount of MSW that is actually available, and verify what tipping fee will accompany the waste.

- Verify that the best location for a WTE plant. A site is needed that is large enough for the conversion equipment, feedstock preparation, and access; has water and other utilities available; can be accessed by trucks for feedstock delivery; and can be connected to the electric grid.

- Perform a legal and regulatory review, including an investigation of the issues involved in securely delivering regional MSW to Fort Sill.

- Interview developers to assess their potential interest in developing this WTE project. Investigate sources of financing. Once the development interest is secured, plans can proceed with the design and final economic calculations.

- Meet with utility representatives to discuss priorities and goals for a WTE plant on Fort Sill. Make all expectations clear and determine whether this project would be beneficial. Assign roles and responsibilities to each party and set a path forward.

Biomass and Waste-to-Energy Sources of Information

Aabakken, J. 2006. "Power Technologies Energy Data Book." National Renewable Energy Laboratory. Fourth Edition. NREL/TP-620-39728. Golden, Colorado. August 2006.

Bain, RL, WA Amos, M Downing, RL Perlack. 2003. "Biopower Technical Assessment: State of the Industry and Technology." National Renewable Energy Laboratory. NREL/TP-51033123. Golden, Colorado. March 2003.

De La Torre Ugarte, DG, ME Walsh, H Shapouri, SP Slinsky. 2000. The Economic Impacts of Bioenergy Crop Production on U.S. Agriculture. University of Tennessee Agricultural Policy Analysis Center. Knoxville, Tennessee. July 2000.

DEQ - Oklahoma Department of Environmental Quality. 2009. Landfill Tonnage Received. Accessed May 7, 2010 at http://www.deq.state.ok.us/lpdnew/SW/Tonnage/2009\%20landfill\%20tonnage\%20received.htm (last updated April 28, 2010).

DSIRE - Database of State Incentives for Renewables \& Efficiency. 2010. Oklahoma: Incentives/Policies for Renewables \& Efficiency: Renewables Energy Goal. Accessed August 30,2010 at http://www.dsireusa.org/incentives/incentive.cfm?Incentive_Code=OK05R\&re=1\&ee=1 (last review June 1, 2010).

EvTEC - Environmental Technology Evaluation Center. 2002. "Environmental Technology Verification Report for the Plasma Enhanced Melter." Civil Engineering Research Foundation. Washington, D.C. December 2002. 
Forest Service. 2010. "Forest Inventory \& Analysis Mapmaker Program on Timber Products Output Studies." United States Department of Agriculture. Accessed May 25, 2010 at http://www.fia.fs.fed.us/program-features/tpo/ (last updated October 26, 2009).

Gallagher, Paul, et al. 2003. "Biomass from Crop Residues: Cost and Supply Estimates." United States Department of Agriculture, Office of the Chief Economist. Washington, DC. February 2003. Accessed June 2010 at http://www.usda.gov/oce/reports/energy/AER819.pdf.

Haq, Zia. 2002. Biomass for Electricity Generation. Energy Information Administration. July 2002. Accessed February 2010 at http://www.eia.doe.gov/oiaf/analysispaper/biomass/.

IEA Energy Technology Essentials. 2007. Biomass for Power Generation and CHP. January 2007. Accessed February 2010 at http://www.iea.org/textbase/techno/essentials3.pdf.

NASS - National Agricultural Statistics Service. 2010. "Quick Stats.” United States Department of Agriculture. Accessed October May 7, 2010 at http://www.nass.usda.gov/Data_and_Statistics/Quick_Stats/.

NOAA - National Oceanic and Atmospheric Administration. 2000. "Total Precipitation in Inches by Month, Climatology by State Based on Climate Division Data: 1971-2000”, accessed August 11, 2010 at http://www.esrl.noaa.gov/psd/data/usclimate/pcp.state.19712000.climo (undated webpage).

Perket, Cary. 2009. “Annual Region Six MSW Landfill Gate Rate Report: Arkansas, Louisiana, New Mexico, Oklahoma, and Texas." In Solid Waste Digest, Digest Year 19. Chartwell Solid Waste Group, The Envirobiz Group, Inc. San Diego, California.

USACE - United States Army Corps of Engineers. 2010. "USACE, Southwestern Division, Tulsa District TERC Task Order 83 Overview", accessed August 6, 2010 at http://www.tercshawgrp.com/swdterc/to83.html (undated webpage).

Walsh, Marie E., et al. 2000. "Biomass Feedstock Availability in the United States: 1999 State Level Analysis.” Oak Ridge National Laboratory. January 2000.

http://bioenergy.ornl.gov/resourcedata/index.html. 


\section{APPENDIX C}

\section{Analysis of Geothermal Plant Opportunities}


Renewable Energy Opportunities at Fort Sill, Oklahoma

Pacific Northwest National Laboratory, March 2011 


\section{Appendix C: Analysis of Geothermal Power Plant Opportunities}

\section{Geothermal Power Plant Technology}

Geothermal power plants use steam from hot water reservoirs found deep below the Earth's surface. The steam rotates a turbine that activates a generator, producing electricity. There are three commercial types of geothermal power plants used to generate electricity (dry steam, flash steam, and binary cycle), and several newer technologies are entering the marketplace (hot dry rock and engineered geothermal systems). The type of plant depends on the state of the fluid (steam, hot water, or mixed) and its temperature.

- Dry Steam power plants use underground steam piped directly from wells to the power plant, where it passes through separators to remove small particles before it is directed into a turbine/generator unit. There are only two known underground resources of steam in the United States: The Geysers in northern California and Yellowstone National Park in Wyoming. The only dry steam plants in the country are at The Geysers.

- Flash Steam power plants use geothermal resources that produce high-temperature hot water or a combination of steam and hot water. This very hot water (reservoirs greater than $360^{\circ} \mathrm{F}$ or $182^{\circ} \mathrm{C}$ ) flows up through wells in the ground under its own pressure. As it flows upward and the pressure decreases, some of the hot water boils (flashes) into steam. The steam is then separated from the water and used to power a turbine/generator. Leftover water and condensed steam are injected back into the reservoir, making this a sustainable resource. Depending on the temperature resource, it may be possible to use a second flash tank, where more steam at a lower pressure is separated for generation (double flash plant).

- Binary Cycle power plants utilize a second fluid in a closed cycle to operate the turbine, instead of direct geothermal steam. These plants operate on water at lower temperatures of about $225^{\circ}-360^{\circ} \mathrm{F}\left(107^{\circ}-182^{\circ} \mathrm{C}\right)$. The heat from the hot water is used to boil a working fluid, usually an organic compound with a low boiling point. The working fluid is vaporized in a heat exchanger and used to turn a turbine. The water is then injected back into the ground to be reheated. The water and the working fluid are kept separated during the whole process, so there is minor or no contamination. The advantage of the binary cycle plant is that it can operate with lower temperature water by using working fluids that have an even lower boiling point than water. Binary power plants are available in smaller scales such as 200 to $1,000 \mathrm{~kW}$.

- Hot Dry Rock (HDR) geothermal production utilizes high temperature rocks found deep (several kilometers) below the surface by pumping high-pressure water down a borehole into a heat zone. The water captures the heat of the rock by traveling through fractures until it is forced out a second borehole and used to generate electricity. Once the water has cooled, it is pumped back underground to heat up again. This process is most easily utilized in locations with natural geothermal systems with existing cracks or pore spaces.

- Engineered or Enhanced Geothermal Systems (EGS) are similar to HDR systems. In locations where there are few cracks and connected pore spaces, or little to no cracks or 
connectivity, cracks can be created or enhanced. The advantage of HDR or EGS is that geothermal resources can be captured for production in non-tectonically active regions. This technology is still very new and expensive.

\section{Geothermal Energy Analysis Approach}

In the 2005 DoD Renewable Energy Assessment, the Navy's Geothermal Office was responsible for the DoD geothermal power assessment. That task was subcontracted to Innovative Technical Solutions, Inc. (ITSI). The Navy and ITSI ranked installations based on their assessment of potential. The utility grade geothermal assessment included 18 installations identified by DoD. Of those installations, five sites were found to have high potential for utility-grade systems. Fort Sill was not found to be one of five sites with high potential for the occurrence of utility-grade geothermal systems, nor was it among the 23 sites that have potential for direct use applications (ITSI 2003).

This analysis utilized the information available from the DoD study, in addition to other readily available sources, to determine if the following conditions exist. The following conditions demonstrate utility-grade geothermal potential:

- Existing power plant operation or developer activity

- One or more wells tested with temperatures in excess of $212^{\circ} \mathrm{F}\left(100^{\circ} \mathrm{C}\right)$ logged downhole (at depths less than $3,000 \mathrm{~m}$ )

- Demonstrated high fluid flow rates on the order of 1,000 gallons per minute (gpm) per MW

- Heat flow rates greater than $80 \mathrm{~mW} / \mathrm{m}^{2}$ (milliWatts per square meter)

- Other exploration data and information available $\left(\geq 212^{\circ} \mathrm{F}\left(100^{\circ} \mathrm{C}\right)\right.$ not proven $)$.

\section{Geothermal Resource Characterization}

Geothermal resources include hot springs, geysers, and underground resources of pressurized water and steam accessible via wells, as well as dry steam, hot water, hot dry rocks, and lowtemperature geothermal heat. A known geothermal resource area is an area in which the geology, nearby discoveries, competitive interests, or other indicators show that potential for extraction of geothermal steam or associated geothermal resources are sufficient to warrant consideration.

For commercial use, it is necessary to have a geothermal reservoir capable of providing hydrothermal (hot water and steam) resources with sufficiently high flow rates. For example, with a typical binary system, 1-MW of electricity can be generated from a single well with a relatively low geothermal fluid temperature of about $230^{\circ} \mathrm{F}\left(110^{\circ} \mathrm{C}\right)$ and a high fluid production rate of 1,000 gpm (MIT 2006). However, if the fluid production is limited to only $430 \mathrm{gpm}$, generating the same 1-MW of electricity requires a much higher fluid temperature of approximately $300^{\circ} \mathrm{F}\left(150^{\circ} \mathrm{C}\right)(\mathrm{MIT} 2006)$. Obtaining both a high temperature of $300^{\circ} \mathrm{F}\left(\sim 150^{\circ} \mathrm{C}\right)$ and a high production rate of $\sim 1,000$ gpm could yield $2.5-\mathrm{MW}$ of power, resulting in a much more valuable resource. 
Geothermal plants operate in regions with high heat flow rates. Heat flow values above $80 \mathrm{~mW} / \mathrm{m}^{2}$ are considered characteristic of a viable geothermal resource. Productive heat flows are generally greater than $150 \mathrm{~mW} / \mathrm{m}^{2}$ (Blackwell et al. 2003). According to the Geothermal Map of the United States (SMU 2004), the heat flow in the Fort Sill region appears to be 45-55 $\mathrm{mW} / \mathrm{m}^{2}$, indicating very low potential. Fort Sill is located in the Wichita uplift of the Interior Lowlands physiographic province. The Interior Lowlands is one of the ancient geologic provinces, characterized by low geothermal heat flow.

Utility-grade geothermal energy requires temperatures in excess of $212^{\circ} \mathrm{F}\left(100^{\circ} \mathrm{C}\right)$ at depths less than $3 \mathrm{~km}$. Subsurface temperatures at Fort Sill are estimated from nearby borehole data available from the Southern Methodist University geothermal database (SMU 2010), and the Oregon Institute of Technology's Geo-Heat Center (GHC 2004). Geothermal gradients provided from several deep $(2,500-5,600 \mathrm{~m})$ oil and gas wells located near Fort Sill are consistently low, ranging from 14 to $22^{\circ} \mathrm{C} / \mathrm{km}$. The nearest borehole for which measured heat flow data is available is located approximately 7 miles north of Fort Sill (Figure C-1). The thermal gradient observed for this borehole is approximately $16^{\circ} \mathrm{C} / \mathrm{km}$ and the maximum temperature at a bottomhole depth of $2,949 \mathrm{~m}$ was only $158^{\circ} \mathrm{F}\left(70^{\circ} \mathrm{C}\right)$ (SMU 2010), which is insufficient for geothermal power generation.

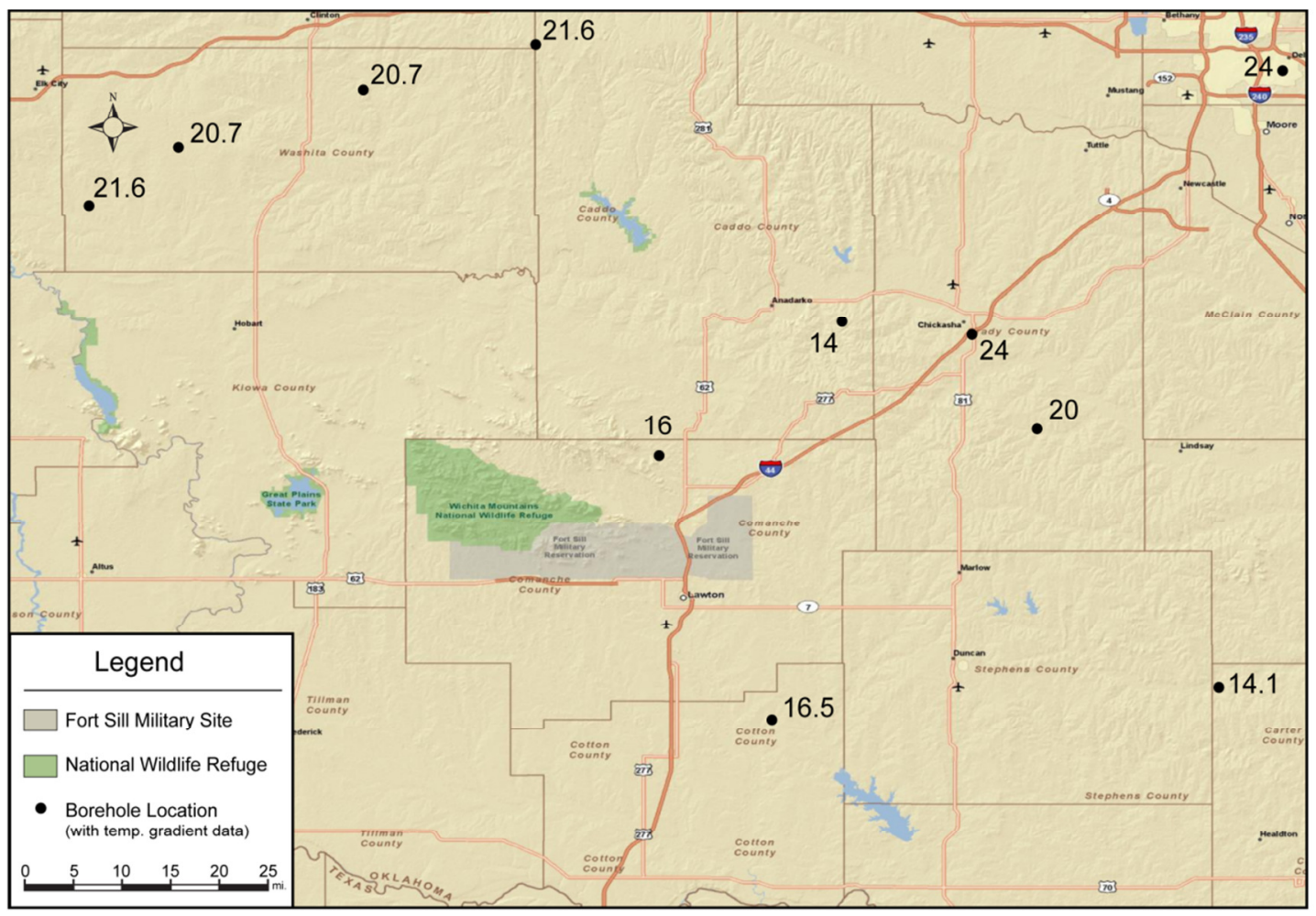

Figure C-1: Location of Boreholes with Published Geothermal Data Near Fort Sill, Oklahoma. 


\section{Geothermal Power Plants: Economic and Other Analysis Parameters}

Geothermal power costs are influenced by capital costs for land, drilling, and the physical plant. Capital costs range from $\$ 1,500$ to $\$ 4,000$ per installed $\mathrm{kW}$. Capital costs for flash steam plants tend to be less expensive than binary plants. Plant life spans are typically 30 to 45 years.

Capital costs include:

- Initial development work: land leasing, exploration, permitting, test well costs

- Infrastructure: roads, water supply, utilities

- Well field drilling: production wells in addition to already drilled confirmation wells

- Steam and brine gathering system: pipes and brine separation equipment

- Power plant: physical equipment for energy conversion, including substation

- Interconnection: link of the power plant substation to the transmission corridor

- Soft costs: developers' fees, overhead, financing costs, legal fees, etc.

Geothermal wells are drilled to depths of 200 to 1,500 meters for low- and medium-temperature systems. For high-temperature systems, wells are drilled 700- to 3,000-meters deep. Each well can cost between $\$ 1$ and $\$ 4$ million to drill and a geothermal field may consist of between 10 to 100 wells.

The project cost is also affected by the cost of operation and maintenance (O\&M), the amount of power generated, and the market value of the power. Operating costs range from 0.4 to $2.6 \phi / \mathrm{kWh}$ for conventional geothermal power plants (Shibaki 2003, Hance 2005). Operating plants at over $90 \%$ capacity will result in higher O\&M costs. Larger plant size means lower per$\mathrm{kWh}$ operating costs.

\section{Findings: Geothermal Power Plants}

According to existing data, Fort Sill lacks naturally occurring hot water/steam fields and elevated temperatures at economic depths (less than $3000 \mathrm{~m}$ ). Thus, the economic calculations for geothermal energy production at the installation were not run. This assessment, which is focused on utility-scale electricity generation, did not examine the potential for direct-use applications of geothermal resources such as space heating, aquaculture, and industrial processes.

\section{Geothermal Power Plants: Next Steps}

Because sufficient geothermal resources are not present at Fort Sill, no immediate action should be taken unless the overall situation changes dramatically. Considering the geology of the area in which Fort Sill is located, it is unlikely that there will be any changes in the near future.

\section{Geothermal Power Plant Sources of Information}

Blackwell, David, Kenneth Wisian, Maria Richards, Mark Leidig, Richard Smith, and Jason McKenna. 2003. Geothermal Resource Analysis and Structure of Basin and Range Systems, Especially Dixie Valley Geothermal Field, Nevada. Southern Methodist University Department of Geological Sciences. Dallas, Texas. http://www.osti.gov/energycitations/servlets/purl/813485-smnwbs/native/813485.PDF. 
MIT - Massachusetts Institute of Technology-led Interdisciplinary Panel. 2006. The Future of Geothermal Energy: Impact of Enhanced Geothermal Systems (EGS) on the United States in the 21st Century. INL/EXT-06-11746, prepared by MIT for the U.S. Department of Energy, Cambridge, Massachusetts. Accessed June 2010 at http://geothermal.inl.gov/publications/future_of_geothermal_energy.pdf.

Hance, Cédric Nathanaël. Factors Affecting Costs of Geothermal Power Development. Geothermal Energy Association for the U.S. Department of Energy, Washington, D.C. http://www.geoenergy.org/publications/reports/Factors\%20Affecting\%20Cost\%20of\%20Geothermal\%20Power \%20Development\%20-\%20August\%202005.pdf.

ITSI - Innovative Technical Solutions. 2003. Geothermal Energy Resource Assessment on Military Lands. Innovative Technical Solutions, Inc. for the Department of Defense, NAWS China Lake, Walnut Creek, California. http://www.geothermal.org/GEO_0001.PDF.

Shibaki, Masashi. 2003. Geothermal Energy for Electric Power. A Renewable Energy Policy Project (REPP) Issue Brief, Renewable Energy Policy Project, Washington, D.C. http://www.crest.org/articles/static/1/binaries/Geothermal_Issue_Brief.pdf.

SMU - Southern Methodist University. 2010. SMU Geothermal Databases. SMU Geothermal Laboratory, Dallas, Texas. Accessed January 2010 at http://smu.edu/geothermal/georesou/usa.htm. 


\section{APPENDIX D}

Analysis of Ground Source Heat Pump Opportunities 
Renewable Energy Opportunities at Fort Sill, Oklahoma

Pacific Northwest National Laboratory, March 2011 


\section{Appendix D: Analysis of Ground Source Heat Pump Opportunities}

\section{Ground Source Heat Pump Technology}

Ground source heat pumps (GSHPs) use the stable temperatures of the Earth and groundwater to improve the coefficient of performance of heating and cooling applications for buildings. Common GSHP configurations include open-loop, horizontal closed-loop, and vertical closedloop.

- Open-loop systems use open wells or bodies of water as direct heat transfer mediums to provide cool temperatures in the summer and warm temperatures in the winter. Heat transfer is only needed once, at the building, because groundwater is used directly, and the limited drilling and trenching results in a lower first cost.

- Closed-loop systems use heat transfer fluid inside a sealed pipe to exchange heat with the earth. Closed-loop systems have lower pumping requirements and are more efficient than open-loop systems. However, soil type and moisture content is more critical to the performance of these systems, and the trenching and drilling significantly increases first cost.

In horizontal-loops, all the piping lies at the same depth in the ground. The piping is laid in shallow trenches, and heat transfer takes place across the pipe wall between the fluid and the subsurface soil.

- Vertical closed-loop GSHPs operate using the same mechanism as horizontal ground loops, except that the piping is deployed in vertical boreholes. This is the most efficient configuration because of the more consistent soil temperatures at the depth reached by most boreholes.

GSHPs are applicable in almost any building with both heating and cooling. They can be used in buildings as small as 100 square feet, or up to 1 million square feet. Multiple GSHPs can be used in a single building or the same ground loop can be shared between buildings.

To install GSHPs at a building, the surrounding area will have certain prerequisites, depending on the type of GSHP. Open-loop GSHPs need a water source and sink. The source can be a well or open body of water. After the energy transfer has occurred, the water can be rejected to a secondary well, the open body of water used as the source, another body of water, or a storm drain. Water volume requirements depend on the size of GSHP installed, but typically between 1.5 and 3.0 gallons per minute are needed per cooling ton. This high water use greatly affects the feasibility of open-loop systems in some areas, as do local codes and regulations. Many locales do not want to risk groundwater depletion or contamination.

Fort Sill has expressed interest in using wastewater as a heat source and sink. While this approach is technically feasible, it requires a sufficient quantity or wastewater that is both reliable and close to the building. Fort Sill is also interested in using lakes as a heat source and heat sink. This can be an economical way to implement GSHP, though care should be taken in the design of the system to ensure that lake temperature will not be substantially affected by thermal pollution. 
Horizontal closed-loop GSHPs have a different limiting factor: sufficient land area. The heat transfer for these systems occurs in pipes laid in trenches that are between 100- and 400-feet long per cooling ton, spaced between 6- and 12-feet apart and about 6-feet deep. The soil characteristics and number of pipes per trench determine the pipe length; more pipes (up to six) per trench save land space but require more piping per ton of cooling capacity. The trenching costs make horizontal ground loops more expensive to install than open-loop systems, but if water availability is the only limiting factor, these systems tend to be the most economic.

Where significant land area and water volume is not available, vertical closed-loop GSHPs may be the only option. In these systems, the heat transfer pipes are placed vertically in the ground, at depths of between 75 and 300 feet. Some land area is still required, because the pipe wells need to be spaced at least 15- to 20-feet apart, and 200 to 600 feet of piping are needed per cooling ton. Vertical ground loop systems tend to have the highest first cost of all the GSHP systems because of the cost of drilling multiple boreholes.

The tradeoff between land use, water use, and first cost generally determine which GHSP is appropriate for a particular building. All of these factors need to be taken into account when planning to deploy a GSHP system.

\section{Ground Source Heat Pump Analysis Approach}

For the purposes of this assessment, GSHPs were evaluated using the data from the 2009 Facility Energy Decision System (FEDS) assessment for Fort Sill. Preliminary analyses of open-loop, horizontal closed-loop, and vertical closed-loop configurations were performed for all buildings included in the FEDS assessment.

The FEDS building energy model (see Appendix A) was used to develop a representation of Fort Sill based upon a PNNL data-gathering trip in 2008. All existing buildings at that time were included in the model, and this analysis used the model to assess current cost-effective potential for GSHP retrofits in each of those buildings. Buildings built since 2008 were not added to the model, because buildings that are only a few years old are typically not cost-effective to retrofit, and the types and sizes of the new buildings are still represented. Based on these results, site judgment can be used to determine cost-effectiveness of retrofitting the newer buildings in the future.

Building data was entered for groups of similar buildings based on age, size, and use type (see Table D-1). Table D-2 shows the actual buildings in each building group. Note that only buildings with cost-effective GSHP projects are shown in Table D-2. The FEDS model was updated with current fuel, equipment, labor prices, and fuel use information. 
Table D-1: Building Groups Analyzed in FEDS for GSHPs

\begin{tabular}{|c|c|c|c|c|c|}
\hline \multirow[b]{2}{*}{ Group ID } & \multicolumn{4}{|c|}{ Building Group Description } & \multirow[b]{2}{*}{$\begin{array}{l}\text { Example } \\
\text { Building }\end{array}$} \\
\hline & Use Type & $\begin{array}{l}\text { Average } \\
\text { Size (sf) }\end{array}$ & $\begin{array}{c}\text { Average } \\
\text { Vintage }\end{array}$ & $\begin{array}{c}\text { Number of } \\
\text { Buildings } \\
\text { Represented }\end{array}$ & \\
\hline $1 \mathrm{a}$ & Large Covered Training & 11,332 & 1987 & 32 & 3384 \\
\hline $1 \mathrm{~b}$ & Small Covered Shelter & 964 & 1973 & 76 & 2445 \\
\hline $10 \mathrm{a}$ & Large 1960s Admin & 236,506 & 1966 & 1 & 4700 \\
\hline $10 \mathrm{~b}$ & Small WW1 Admin & 83,912 & 1940 & 4 & 700 \\
\hline $10 \mathrm{c}$ & 1950s Admin & 74,600 & 1958 & 2 & 707 \\
\hline $10 \mathrm{~d}$ & 1950s Admin (Hammerhead) & 37,851 & 1954 & 7 & 3421 \\
\hline $10 \mathrm{e}$ & 1950s Admin (3429 Hammerhead) & 37,317 & 1954 & 7 & 3429 \\
\hline $10 f$ & WWII Small Admin & 3,959 & 1936 & 77 & 2595 \\
\hline $10 \mathrm{~g}$ & 1920s Small Admin & 23,158 & 1925 & 12 & 652 \\
\hline $10 \mathrm{~h}$ & 1960s Small Admin & 5,096 & 1965 & 39 & 3608 \\
\hline $10 \mathrm{i}$ & 1960s Medium Admin & 24,228 & 1963 & 8 & 3162 \\
\hline $10 \mathrm{j}$ & Modern Small Admin & 3,063 & 1990 & 50 & 3203 \\
\hline $10 \mathrm{k}$ & Modern Med Admin & 27,346 & 1985 & 9 & 6130 \\
\hline $21 \mathrm{~b}$ & Medical, Clinics & 8,102 & 1978 & 18 & 2913 \\
\hline $23 \mathrm{a}$ & Electronics / Simulator & 3,052 & 1968 & 34 & 6120 \\
\hline $23 b$ & Large Simulation / Battle Lab & 93,908 & 1970 & 1 & 3040 \\
\hline $23 b-2$ & Large Simulation (highbay area) & 47,000 & 1970 & 1 & 3040 \\
\hline $30 \mathrm{a}$ & WWII Barracks & 137,718 & 1934 & 2 & 1602 \\
\hline $30 \mathrm{~b}$ & Early 1980s barracks & 203,536 & 1985 & 5 & 5960 \\
\hline $30 \mathrm{~d}$ & 1960s Army Lodging & 120,027 & 1967 & 2 & 5678 \\
\hline $30 \mathrm{e}$ & 1930s Barracks & 108,071 & 1936 & 3 & 914 \\
\hline $30 f$ & 1950s Barracks (hammerheads) & 38,210 & 1951 & 5 & 3430 \\
\hline $30 \mathrm{~g}$ & Historic Barracks & 15,741 & 1910 & 8 & 1616 \\
\hline $30 \mathrm{~h}$ & 2000s Barracks & 14,696 & 2001 & 10 & 3700 \\
\hline $30 \mathrm{i}$ & 1940s Medium Barracks & 63,739 & 1940 & 3 & 1653 \\
\hline $30 \mathrm{j}$ & WWII Barracks (hammerheads) & 25,795 & 1945 & 10 & 3411 \\
\hline $30 \mathrm{k}$ & 1970s Barracks & 33,843 & 1979 & 9 & 6015 \\
\hline $30 \mathrm{~L}$ & 1960s Barracks & 13,200 & 1965 & 23 & 2857 \\
\hline $30 \mathrm{~m}$ & 1960s Medium Barracks & 27,285 & 1965 & 10 & 3622 \\
\hline $40 \mathrm{a}$ & Unconditioned Storage & 996 & 1970 & 161 & 2309 \\
\hline $40 \mathrm{~b}$ & Enclosed Storage & 10,400 & 1937 & 33 & 1506 \\
\hline $40 \mathrm{c}$ & 1980s Small Storage & 1,153 & 1971 & 99 & 3320 \\
\hline $40 \mathrm{~d}$ & 1990s Storage & 3,475 & 1999 & 65 & 1924 \\
\hline $50 \mathrm{a}$ & Small Plant / Utility Building & 828 & 1968 & 86 & 751 \\
\hline $50 \mathrm{~b}$ & Medium Plant / Utility Building & 3,390 & 1994 & 30 & 3330 \\
\hline $50 \mathrm{c}$ & Small Vehicle Maintenance & 12,714 & 1990 & 14 & 812 \\
\hline
\end{tabular}




\begin{tabular}{|c|c|c|c|c|c|}
\hline \multirow[b]{2}{*}{ Group ID } & \multicolumn{4}{|c|}{ Building Group Description } & \multirow[b]{2}{*}{$\begin{array}{l}\text { Example } \\
\text { Building }\end{array}$} \\
\hline & Use Type & $\begin{array}{l}\text { Average } \\
\text { Size (sf) }\end{array}$ & $\begin{array}{l}\text { Average } \\
\text { Vintage }\end{array}$ & $\begin{array}{c}\text { Number of } \\
\text { Buildings } \\
\text { Represented }\end{array}$ & \\
\hline $50 \mathrm{~d}$ & Medium Vehicle Maintenance & 24,318 & 2004 & 11 & 3391 \\
\hline $50 \mathrm{e}$ & Small Older Vehicle Maintenance & 7,723 & 1954 & 44 & 3391 \\
\hline $50 f$ & Med Older Vehicle Maintenance & 36,578 & 1954 & 10 & 3477 \\
\hline $60 \mathrm{a}$ & Dining Facility & 13,146 & 1960 & 18 & 1935 \\
\hline $60 \mathrm{~b}$ & Police / Fire & 13,341 & 1955 & 10 & 5684 \\
\hline $60 \mathrm{c}$ & Small Exchange Facilities & 8,797 & 1964 & 11 & 6041 \\
\hline $60 \mathrm{e}$ & Tent Dining Facility & 5,000 & 2007 & 2 & 1713 \\
\hline $80 \mathrm{a}$ & Recreation Centers & 5,400 & 1988 & 40 & 6045 \\
\hline $80 \mathrm{~b}$ & Sep / Toilets & 338 & 1984 & 60 & 1620 \\
\hline $80 \mathrm{c}$ & Fitness Centers - Main Gym & 38,475 & 1974 & 3 & 3444 \\
\hline $80 \mathrm{~d}$ & Museum / MWR & 6,898 & 1912 & 28 & 438 \\
\hline $80 \mathrm{e}$ & Fitness Centers (Weights and showers) & 38,475 & 1974 & 3 & 3444 \\
\hline $2 \mathrm{sf}-1$ & 1960s Family Housing Garage/port & 442 & 1957 & 358 & 5768 \\
\hline $2 \mathrm{sf}-2$ & 2000s Family Housing Garage/port & 971 & 2006 & 204 & 5050 \\
\hline $2 \mathrm{sf}-3$ & 1940s Family Housing Garage/port & 1,620 & 1941 & 34 & 2080 \\
\hline $2 \mathrm{sf}-4$ & 2000s Family Housing & 131 & 2004 & 211 & 5476 \\
\hline 30 sf-1 & 1930s Family Housing & 2,721 & 1933 & 91 & 651 \\
\hline $30 \mathrm{sf}-2$ & 1920s Family Housing & 4,521 & 1926 & 38 & 573 \\
\hline $30 \mathrm{sf}-3$ & 1950s Family Housing & 1,386 & 1957 & 153 & 1431 \\
\hline $30 \mathrm{sf}-4$ & 1890s Family Housing & 5,748 & 1894 & 29 & 1316 \\
\hline $30 \mathrm{af}-5$ & 1930s Family Housing & 4,366 & 1938 & 33 & 2076 \\
\hline 30 sf-6 & 1960s Family Housing & 2,759 & 1960 & 152 & 5578 \\
\hline $30 \mathrm{sf}-7$ & 1960s Family Housing & 2,850 & 1963 & 87 & 5799 \\
\hline 30 sf- 8 and 9 & 2000s Family Housing & 12,072 & 2006 & 51 & 5475 \\
\hline $30 \mathrm{sf}-11$ & 1930s Family Housing & 12,301 & 1935 & 24 & 630 \\
\hline
\end{tabular}


Table D-2: Buildings Analyzed in FEDS for GSHPs*

\begin{tabular}{|c|c|c|}
\hline Description & $\begin{array}{l}\text { Group } \\
\text { ID }\end{array}$ & Building Numbers \\
\hline 1920s Small Admin & $10 \mathrm{~g}$ & $5030,1950,1647,208,1651,1945$ \\
\hline 1960s Small Admin & $10 \mathrm{~h}$ & $\begin{array}{l}2605,2855,2437,2436,3669,3608,3560,3559,60,811,3161,3168,3169, \\
7801,3435,1613,2304,3662,3668,3623,3609,3683,3439,2472,3431, \\
2717,2719,1,3360,2490,2463,2478,2469,3460,3466,3479\end{array}$ \\
\hline Modern Small Admin & $10 \mathrm{j}$ & $\begin{array}{l}2276,4116,4907,3204,2635,3203,3202,3201,3200,2320,3382,1450, \\
6483,6482,7535,7533,1465,4705,2412,6100,3283,7958,7826,7825, \\
7824,7823,7816,7815,7814,7813,6032,2480,5679,6112,6102,4900 \\
1717,6700,1492,1491,1489,6099,7301,7001,3043,7104,7401,2362\end{array}$ \\
\hline Medical, Clinics & $21 \mathrm{~b}$ & $\begin{array}{l}3337,4303,3336,6039,6021,605,2913,6037,838,7290,2442,3445,2775, \\
2772,2777,2776,7291,721\end{array}$ \\
\hline $\begin{array}{l}\text { Large Simulation (high } \\
\text { bay area) }\end{array}$ & $23 b-2$ & 3040 \\
\hline WWI Barracks & $30 \mathrm{a}$ & 1602,1603 \\
\hline Early 1980s barracks & $30 \mathrm{~b}$ & $6050,5970,5960,5955,6007$ \\
\hline $\begin{array}{l}\text { 1950s barracks } \\
\text { (hammerheads) }\end{array}$ & $30 f$ & $2471,2470,475,3428,3430$ \\
\hline Historic Barracks & $30 \mathrm{~g}$ & $1313,1606,1615,1614,1605,1616,343,380$ \\
\hline WWII Barracks & $30 \mathrm{j}$ & $3414,3413,3412,3411,3415,510,5715,460,635,1307$ \\
\hline $\begin{array}{l}\text { Small Vehicle } \\
\text { Maintenance }\end{array}$ & $50 \mathrm{c}$ & $\begin{array}{l}\text { 6490, 3987, 239, 5446, 1494, 6168, 6153, R6240, 3386, 813, 3990C, 3041, } \\
812,6115\end{array}$ \\
\hline $\begin{array}{l}\text { Medium Vehicle } \\
\text { Maintenance }\end{array}$ & $50 \mathrm{~d}$ & $1966,2284,2282,2280,2440,2281,2283,3393,3391,3348,3347$ \\
\hline $\begin{array}{l}\text { Small Older Vehicle } \\
\text { Maintenance }\end{array}$ & $50 \mathrm{e}$ & $\begin{array}{l}2182,5033,2493,3354,3495,3463,1903,2652,1948,3356,2487,1505, \\
1507,2475,2460,3357,3496,1502,1501,3363,3493,2466,3457,3482, \\
3477,3362,2454,340,6103,2524,2522,1510,1936,1953,2285,1514,2340, \\
3038,6110,2457,2496,1518,1933,2178\end{array}$ \\
\hline $\begin{array}{l}\text { Med Older Vehicle } \\
\text { Maintenance }\end{array}$ & $50 \mathrm{f}$ & $840,2258,4908,4915,1935,4920,2036,3990,1509,1504$ \\
\hline Police / Fire & $60 \mathrm{~b}$ & $1490,1802,930,6041,1649,5031,3500,1612,1617,2952$ \\
\hline $\begin{array}{l}\text { Small Exchange } \\
\text { Facilities }\end{array}$ & $60 \mathrm{c}$ & $1712,6036,1713,1723,2773,3985,2444,4117,2861,2865,4114$ \\
\hline $\begin{array}{l}\text { Recreation Centers - club } \\
\text { house }\end{array}$ & $80 \mathrm{a}$ & $\begin{array}{l}7480,7465,7464,7463,7302,7002,6797,6599,6539,6098,6045,5690, \\
4997,7454,4746,4745,4744,3950,3379,3265,2503,2502,1721,7451, \\
1466,1457,1293,7402,1292,1291,1290,1279,1278,1276,1270,935,602, \\
502,153,3\end{array}$ \\
\hline Museum / MWR & $80 \mathrm{~d}$ & $\begin{array}{l}5037,3260,442,443,441,6008,1503,438,3280,346,435,345,160,3025, \\
336,327,326,432,425,440,155,447,469,446,449,366\end{array}$ \\
\hline
\end{tabular}

* Building groups with no economically feasible projects are not included in this list.

Site-specific TMY (typical meteorological year) weather data and soil/ground characteristics were also used in the analysis. The weather data used for this analysis came from Lawton Municipal Airport. Soil testing and groundwater evaluation is necessary before actual costs can be determined. For local soil conditions, this analysis uses the following assumptions, based on soil thermal conductivity testing by Geothermal Resource Technologies, Inc. at the Dining Facility South Site. Though soil conditions may vary throughout the site, access to actual conductivity test results was very helpful for our analysis. 
- Soil thermal diffusivity: $0.0325 \mathrm{ft}^{2} / \mathrm{hr}$

- Average thermal conductivity: $1.09 \mathrm{Btu} / \mathrm{hr} \cdot \mathrm{ft} \cdot{ }^{\circ} \mathrm{F}$

- Ground water temperature: $64.3^{\circ}$

- Depth to bedrock: $45 \mathrm{ft}$.

The model does not consider site limitations like land area or water source availability. The assumption is that there are sufficient thermal sources/sinks in place. Also, soil and water characteristics can change across the same site, so the data used for this assessment is, while representative, not precise enough to use in the design of a specific system.

\section{Ground Source Heat Pump Resource Characterization}

GSHP assessments using FEDS have been completed at many sites in the past using the same analytic approach. The results developed here agree with previous findings. In general, conditions favoring replacement of existing heating and cooling systems with GSHPs include:

- Replacing old equipment. Equipment at the end of its useful life that will soon be replaced provides further economic incentive for GSHP installations, particularly if existing ductwork can be reused.

- More extreme climates. Cold winters, hot summers, or large daily temperature swings allow GSHPs to operate more efficiently than other electric cooling and heating systems. The cost of heating operation is comparable to non-electric heating systems.

- High cost of non-electric fuels. If electricity is less than approximately 3.5 times as expensive per Btu than other fuels, GSHPs will generally be cost-effective. If no other fuel option is available and electric costs are high, GSHPs will be less expensive to operate than air-source heat pumps.

GSHPs are often not cost-effective in a building that:

- Does not have both cooling and heating. A building needs to be both heated and cooled to take advantage of the GSHP efficiency in both modes. However, most of the savings are realized in the heating mode, so buildings with no cooling can still benefit from GSHPs.

- Does not currently have ductwork. Installing a new air distribution system in addition to the conditioning equipment generally adds too much cost for a GSHP retrofit, unless the building is modified to allow zone-level heat pumps to be used in conjunction with a water loop, connecting the terminal units to a shared ground loop.

- Is newer. Newer buildings (less than about 4 years old) generally have fairly efficient equipment (or at least the performance has not yet degraded significantly). As a result, premature replacement with a GSHP is generally uneconomic. In addition, the building envelope tends to be better, lengthening payback duration. 
- Is located in a mild climate. Buildings in fairly mild climates do not have the temperature extremes that make the ground loop important. A standard air-source heat pump would probably suffice.

- Uses an air-source heat pump. An air-source heat pump has many of the benefits of a GSHP except in extreme temperature conditions. These extreme temperature conditions often are not enough to justify replacement.

- Is connected to a central energy plant (unless the CEP will be abandoned). Although we often consider central energy systems as big energy wasters, on a building-by-building basis (which does not account for distribution losses) it is difficult to justify replacement. Centralized chiller plants can use larger, more efficient water-cooled units and can stage several chillers to run closer to full load (most efficient mode).

\section{Ground Source Heat Pumps: Economic and Other Analysis Parameters}

FEDS allows two primary financing options: appropriated funding (using energy conservation investment program, or ECIP, funds) and alternative financing (utility energy services contract, or UESC, or energy saving performance contract, or ESPC). The parameters for alternative financing can be adjusted to match the options available to the site. For this assessment, a project life of 25 years and a third-party interest rate of $5 \%$ were used.

FEDS uses the site electric rate schedule and energy costs to determine fuel costs and savings for GSHP retrofits. The entire rate schedule is used so that consumption and demand can be calculated on a time-of-use basis. Fossil fuel prices were determined using FY 2009 Army Energy and Water Reporting System (AEWRS) data. The following marginal energy costs were used for the analysis.

- Electricity: $1.36 ф / \mathrm{kWh}(\$ 3.99 / \mathrm{MMBtu})$

- Natural Gas: \$9.57/MMBtu.

The electric rate structure includes both standard demand charges and demand ratchets. The effective demand charge was determined to be $\$ 4.84 / \mathrm{kW}$. The average installed cost per unit of cooling capacity in buildings that were found to be cost-effective is as follows:

- Open loop: $\$ 1,631$ per ton

- Horizontal closed-loop: \$2,566 per ton

- Vertical closed-loop: $\$ 4,279$ per ton.

The difference in costs reflects economies of scale working in favor of larger projects. Where fewer or smaller units are being installed, the price increases comparatively with a similar technology. Open-loop systems tend to have the lowest installed cost, especially for larger building. Costs are only shown for projects that were found to be cost-effective in this analysis. 


\section{Findings: Ground Source Heat Pumps}

GSHPs were found to be economic in some situations at Fort Sill. Fort Sill has very low electricity rates, even after demand charges are considered. For buildings with natural gas heating, low electricity prices and high natural gas prices tend to improve project economics. GSHPs work well in buildings with relatively balanced heating and cooling loads because the installed capacity can be fully utilized in both the summer and winter. Although Fort Sill has more heating-degree-days than cooling-degree-days, many buildings at Fort Sill have relatively balanced heating and cooling loads because of internal heat gains (e.g., electrical equipment, motors, etc.). The analysis shows that open-loop, horizontal closed-loop, and vertical closedloop GSHPs are cost-effective for various building types.

The simple payback values presented in Table D-3 are the average values for all buildings with cost-effective projects within that particular group. Some of the building groups in Table D-3 contain buildings served by different fuels or with other noteworthy differences. To find the economic characteristics for buildings with specific heating and cooling technologies within a group, see Appendix D-1, which contains the economic results for each building group examined.

Table D-3: Simple Payback Period for Building Groups Analyzed in FEDS for GSHPs

\begin{tabular}{|c|c|c|c|c|c|c|c|}
\hline \multirow{2}{*}{ Description } & \multirow{2}{*}{$\begin{array}{l}\text { Group } \\
\text { ID }\end{array}$} & \multicolumn{3}{|c|}{ Alternative Financing } & \multicolumn{3}{|c|}{ Appropriated Financing } \\
\hline & & Open** & Horz $\dagger$ & Vert $+\dagger$ & Open & Horz & Vert \\
\hline 1920s Small Admin & $10 \mathrm{~g}$ & - & - & - & 14.2 & - & - \\
\hline 1960s Small Admin & $10 \mathrm{~h}$ & - & - & - & - & 15.5 & - \\
\hline Modern Small Admin & $10 \mathrm{j}$ & - & - & - & - & 11.8 & - \\
\hline Medical Clinics & $21 b$ & - & - & - & 15.1 & 15.2 & - \\
\hline Large Simulation (high bay area) & $23 b-2$ & 5.2 & 6.3 & - & 4.5 & 5.8 & 14.4 \\
\hline WWI Barracks & $30 \mathrm{a}$ & 10.5 & - & - & 8.1 & 16.5 & - \\
\hline Early 1980s barracks & $30 b$ & 10.7 & - & - & 10.9 & - & - \\
\hline 1950s Barracks (hammerheads) & $30 f$ & - & - & - & 21.0 & - & - \\
\hline Historic Barracks & $30 \mathrm{~g}$ & - & - & - & 11.9 & 11.6 & 18.1 \\
\hline WWII Barracks & $30 \mathrm{j}$ & 15.3 & - & - & 17.4 & 13.3 & - \\
\hline Small Vehicle Maintenance & $50 \mathrm{c}$ & - & - & - & - & 15.1 & - \\
\hline Medium Vehicle Maintenance & $50 \mathrm{~d}$ & - & - & - & 15.8 & - & - \\
\hline $\begin{array}{l}\text { Small Older Vehicle } \\
\text { Maintenance }\end{array}$ & $50 \mathrm{e}$ & 13.1 & 11.8 & - & 10.8 & 10.2 & - \\
\hline $\begin{array}{l}\text { Medium Older Vehicle } \\
\text { Maintenance }\end{array}$ & $50 f$ & 8.0 & 11.4 & - & 7.6 & 11.6 & - \\
\hline Police / Fire Buildings & $60 b$ & - & - & - & 13.0 & 17.0 & - \\
\hline Small Exchange Facilities & $60 c$ & - & - & - & 7.4 & 7.3 & 13.3 \\
\hline Recreation Centers - Club House & $80 \mathrm{a}$ & - & - & - & - & 11.1 & - \\
\hline Museum / MWR & $80 \mathrm{~d}$ & - & - & - & - & 16.3 & - \\
\hline
\end{tabular}

* Building groups with no economically feasible projects are not included in this list

** Open-loop GSHP

$\uparrow$ Horizontal closed-loop GSHP

$\dagger \dagger$ Vertical closed-loop GSHP 
Open-loop systems tend to have the best economics, followed by horizontal then vertical closedloop systems. This is primarily because the initial costs of open-loop systems are much lower than horizontal and vertical systems. One of the main costs for open-loop GSHPs is drilling the well. Because small systems still need a well, albeit a smaller well, the cost per unit of capacity for open-loop systems increases for smaller systems. As a result, closed-loop systems are occasionally more cost-effective than open-loop systems for buildings with small loads.

As seen in the results above, GSHP retrofits are more likely cost-effective in buildings with old, inefficient heating systems. GSHP systems also work best when the heating and cooling capacity are correctly sized to meet the building's load (except in hybrid systems). For Fort Sill's soil characteristics, the heating capacity of GSHP systems is typically slightly higher than the cooling capacity. It is more likely for GSHP systems to be cost-effective in buildings with similar capacity needs. Hybrid GSHP systems, which Fort Sill has considered, offer a good alternative when building heating and cooling demands are not aligned. Hybrid systems reduce capital costs by sizing the ground loop to meet the cooling demands and installing a boiler help meet heating demands (for a heating dominated climate).

Projects with appropriated funding, such as projects funded through the ECIP program, have shorter payback periods than UESC projects. UESC projects usually have higher capital costs because the projects are financed. In addition, project savings must be shared between the site and the financier. However, UESC projects were found to be cost-effective for open-loop and horizontal closed-loop GSHPs in various building sets. No cost-effective vertical closed-loop retrofits were identified at this time.

The majority of buildings at Fort Sill are heated with natural gas. Most of the cost-effective retrofits were found in building currently served by natural gas. However, some cost-effective GSHP projects in buildings served by central energy plants (CEPs) were also identified. The GSHP projects for buildings served by CEPs, listed in Appendix D-1, were found to be costeffective without decentralizing the CEP or abandoning the loops. This means that the project is justified without considering the savings typically associated with abandoning a CEP, such as Maintenance cost savings or the reduction of distribution losses. The abandonment of loops or CEPs in favor of GSHP systems was not explicitly considered in this analysis. More information on CEP options can be found in the Fort Sill's Energy Engineering Analysis Program (EEAP) report from March, 2009. If loop or plant abandonment is considered in the future, GSHPs should be considered for replacement heating and cooling technologies, although life-cycle costeffectiveness will need to be considered on a case-by-case basis.

The analysis undertaken to assess the potential for GSHPs on Fort Sill applies only to installing systems in existing buildings. For new buildings, project economics tend to be considerably better because of the ability to optimize a building's design with a GSHP in mind. Also, for new construction, only the increased cost relative to traditional systems, rather than the total GSHP cost, needs to be considered when assessing GSHP economics. In some cases, the cost increase may be relatively small.

The total potential energy savings for Fort Sill is difficult to estimate accurately because it depends on which type of GSHP technology is implemented and how many buildings have restrictions that prevent GSHPs. However, if all cost-effective GSHPs were implemented and 
there were no land or water use restrictions, the annual energy savings would be approximately 190,000 MMBtu, or about 17\% of total building energy use.

\section{Ground Source Heat Pumps: Next Steps}

Fort Sill should consider the presented results and choose buildings to investigate in detail. Starting with the projects that present the best economic results, determine which specific buildings are appropriate for GSHP systems. For horizontal systems, determine if there is sufficient space for wells. Vertical systems require much less area, but space must also be considered, especially for larger systems. Finally, determine whether local laws, regulations, and the site's groundwater policies allow for the use of open-loop systems. Depending on the needs of the funding source (i.e., ECIP projects should be at least $\$ 750,000$ in capital cost), Fort Sill may need to group multiple GSHP or combine GSHPs with other renewable energy or energy efficiency projects. Grouping similar buildings may reduce capital cost requirements by taking advantage of economies of scale.

Buildings that are deemed to be appropriate for GSHPs can then be put into a project proposal, and experienced designers in the area can be contacted to develop detailed project designs.

For new construction, conduct soil tests during site excavations. Work with designers to incorporate GSHPs early in the process. Choose a method of funding as necessary and make sure it is available. If building heating and cooling loads do not match GSHP capacities, hybrid systems can be used. At Fort Sill, cooling loads likely exceed heating loads in buildings with high internal gains, such as office, administration, or electronics buildings. Fort Sill has extensive experience with hybrid GSHPs. Hybrid systems minimize GSHP heating and cooling load imbalances, which lead to long term ground temperature changes and reduced performance. Hybrid GSHPs also reduce initial costs by fully utilizing the heating and cooling capacities of GSHP systems. By leveraging previous experience, Fort Sill can continue to implement hybrid systems, improve system designs, and reduce initial costs as designers and installers become more familiar with these systems.

Fort Sill should also consider using GSHPs for buildings on their proposed micro grid. Using GSHPs to efficiently heat and cool buildings will reduce the load on the micro grid. Lower loads will allow for smaller solar and wind power systems. Because the micro grid will be powered by relatively expensive power sources, GSHP should have strong economics.

\section{Ground Source Heat Pump Sources of Information}

FEMP - Federal Energy Management Program. 2001. Federal Technology Alert: Ground Source Heat Pumps Applied to Federal Facilities - Second Edition. DOE/EE-0245, Federal Energy Management Program, U.S. Department of Energy, Washington, DC. Accessed May 2010 at http://www1.eere.energy.gov/femp/pdfs/FTA_gshp.pdf.

FEMP- Federal Energy Management Program. 2001. Assessment of Hybrid Geothermal Heat Pump Systems. DOE/EE-0258, Federal Energy Management Program, U.S. Department of Energy, Washington, DC. Accessed July 2010 at http://www1.eere.energy.gov/femp/pdfs/hyhgp_tir.pdf. 
Goetzler, W, R Zogg, H Lisle, and J Burgos. 2009. Ground Source Heat Pumps: Overview of Market Status, Barriers to Adoption, and Options for Overcoming Barriers. Prepared by Navigant Consulting, Inc. for the U.S. Department of Energy, Energy Efficiency and Renewable Energy Geothermal Technologies Program, Washington, DC. Accessed May 2010 at http://www1.eere.energy.gov/geothermal/pdfs/gshp_overview.pdf.

Hughes, P. 2008. Geothermal (Ground-Source) Heat Pumps: Market Status, Barriers to Adoption, and Actions to Overcome Barriers. ORNL/TM-2008/232, Energy and Transportation Science Division, Oak Ridge National Laboratory, Oak Ridge, TN. Accessed May 2010 at http://www1.eere.energy.gov/geothermal/pdfs/ornl_ghp_study.pdf. 


\section{Appendix D-1: Detailed GSHP Economic Results}

Appendix D-1 presents the estimated simple payback period, savings to investment ratio, and installed capital cost for each GSHP project that was found to be cost-effective. The economic results vary based on the type of building, current heating and cooling technologies, and the funding source.

Table D-1-1: Simple Payback Period for Building Groups Analyzed in FEDS for GSHPs

\begin{tabular}{|c|c|c|c|c|c|c|c|}
\hline $\begin{array}{l}\text { Funding } \\
\text { Source }\end{array}$ & Description & $\begin{array}{l}\text { Group } \\
\text { ID }\end{array}$ & $\begin{array}{c}\text { Current Heating/Cooling } \\
\text { Technology }\end{array}$ & $\begin{array}{l}\text { Retrofit } \\
\text { Technology }\end{array}$ & $\begin{array}{c}\text { Payback } \\
\text { Period } \\
\text { (years) }\end{array}$ & $\begin{array}{l}\text { Savings to } \\
\text { Investment } \\
\text { Ratio }\end{array}$ & $\begin{array}{l}\text { Installed } \\
\text { Capital } \\
\text { Cost }\end{array}$ \\
\hline ECIP & 1920s Small Admin & $10 \mathrm{~g}$ & $\begin{array}{l}\text { Natural Gas Conventional Furnace } \\
\text { / Electric Package Unit }\end{array}$ & Open-Loop GSHP & 14.2 & 1.2 & $\$ 752,466$ \\
\hline ECIP & 1960s Small Admin & $10 \mathrm{~h}$ & $\begin{array}{l}\text { Natural Gas Floor-Based Radiant } \\
\text { Heating System / Electric Air- } \\
\text { Cooled Chiller }\end{array}$ & $\begin{array}{l}\text { Horizontal Closed- } \\
\text { Loop GSHP }\end{array}$ & 15.5 & 1.1 & $\$ 1,820,201$ \\
\hline ECIP & $\begin{array}{l}\text { Modern Small } \\
\text { Admin }\end{array}$ & $10 \mathrm{j}$ & $\begin{array}{l}\text { Natural Gas Conventional Boiler / } \\
\text { Electric Air-Cooled Chiller }\end{array}$ & $\begin{array}{l}\text { Horizontal Closed- } \\
\text { Loop GSHP }\end{array}$ & 11.8 & 1.4 & $\$ 915,526$ \\
\hline ECIP & Medical, Clinics & $21 b$ & $\begin{array}{l}\text { Natural Gas Conventional Boiler / } \\
\text { Electric Air-Cooled Chiller }\end{array}$ & $\begin{array}{l}\text { Horizontal Closed- } \\
\text { Loop GSHP }\end{array}$ & 15.2 & 1.1 & $\$ 1,136,499$ \\
\hline ECIP & Medical, Clinics & $21 b$ & $\begin{array}{l}\text { Natural Gas Conventional Boiler / } \\
\text { Electric Air-Cooled Chiller }\end{array}$ & Open-Loop GSHP & 15.1 & 1.1 & $\$ 1,000,142$ \\
\hline ECIP & $\begin{array}{l}\text { Large Sim (highbay } \\
\text { area) }\end{array}$ & $23 b-2$ & $\begin{array}{l}\text { Natural Gas Conventional Boiler / } \\
\text { Electric Air-Cooled Chiller }\end{array}$ & $\begin{array}{l}\text { Horizontal Closed- } \\
\text { Loop GSHP }\end{array}$ & 5.8 & 3.3 & $\$ 145,236$ \\
\hline UESC & $\begin{array}{l}\text { Large Sim (highbay } \\
\text { area) }\end{array}$ & $23 b-2$ & $\begin{array}{l}\text { Natural Gas Conventional Boiler / } \\
\text { Electric Air-Cooled Chiller }\end{array}$ & $\begin{array}{l}\text { Horizontal Closed- } \\
\text { Loop GSHP }\end{array}$ & 6.3 & 2.6 & $\$ 125,203$ \\
\hline ECIP & $\begin{array}{l}\text { Large Sim (highbay } \\
\text { area) }\end{array}$ & $23 b-2$ & $\begin{array}{l}\text { Natural Gas Conventional Boiler / } \\
\text { Electric Air-Cooled Chiller }\end{array}$ & Open-Loop GSHP & 4.5 & 4.1 & $\$ 123,719$ \\
\hline UESC & $\begin{array}{l}\text { Large Sim (highbay } \\
\text { area) }\end{array}$ & $23 b-2$ & $\begin{array}{l}\text { Natural Gas Conventional Boiler / } \\
\text { Electric Air-Cooled Chiller }\end{array}$ & Open-Loop GSHP & 5.2 & 3.1 & $\$ 106,655$ \\
\hline ECIP & $\begin{array}{l}\text { Large Sim (highbay } \\
\text { area) }\end{array}$ & $23 b-2$ & $\begin{array}{l}\text { Natural Gas Conventional Boiler / } \\
\text { Electric Air-Cooled Chiller }\end{array}$ & $\begin{array}{l}\text { Vertical Closed- } \\
\text { Loop GSHP }\end{array}$ & 14.4 & 1.3 & $\$ 440,491$ \\
\hline ECIP & WWI Barracks & $30 \mathrm{a}$ & $\begin{array}{l}\text { Natural Gas Conventional Boiler / } \\
\text { Electric Air-Cooled Chiller }\end{array}$ & $\begin{array}{l}\text { Horizontal Closed- } \\
\text { Loop GSHP }\end{array}$ & 16.2 & 1.1 & $\$ 988,179$ \\
\hline ECIP & WWI Barracks & $30 \mathrm{a}$ & $\begin{array}{l}\text { Natural Gas Conventional Boiler / } \\
\text { Electric Air-Cooled Chiller }\end{array}$ & Open-Loop GSHP & 8 & 2.1 & $\$ 472,200$ \\
\hline UESC & WWI Barracks & $30 \mathrm{a}$ & $\begin{array}{l}\text { Natural Gas Conventional Boiler / } \\
\text { Electric Air-Cooled Chiller }\end{array}$ & Open-Loop GSHP & 10.3 & 1.5 & $\$ 407,069$ \\
\hline ECIP & Early 1980 s barracks & $30 \mathrm{~b}$ & $\begin{array}{l}\text { Natural Gas Conventional Boiler / } \\
\text { Central Chilled Water with AHU }\end{array}$ & Open-Loop GSHP & 10.9 & 1.9 & $\$ 2,416,739$ \\
\hline UESC & Early 1980s barracks & $30 b$ & $\begin{array}{l}\text { Natural Gas Conventional Boiler / } \\
\text { Central Chilled Water with AHU }\end{array}$ & Open-Loop GSHP & 10.7 & 1.5 & $\$ 2,083,395$ \\
\hline ECIP & $\begin{array}{l}\text { 1950s barracks } \\
\text { (hammerheads) }\end{array}$ & $30 \mathrm{f}$ & $\begin{array}{l}\text { Natural Gas Conventional Boiler / } \\
\text { Central Chilled Water with AHU }\end{array}$ & Open-Loop GSHP & 21.4 & 1.1 & $\$ 318,328$ \\
\hline ECIP & $\begin{array}{l}\text { 1950s barracks } \\
\text { (hammerheads) }\end{array}$ & $30 \mathrm{f}$ & $\begin{array}{l}\text { Natural Gas Conventional Boiler / } \\
\text { Central Chilled Water with AHU }\end{array}$ & Open-Loop GSHP & 21.2 & 1.1 & $\$ 212,219$ \\
\hline ECIP & Historic Barracks & $30 \mathrm{~g}$ & $\begin{array}{c}\text { Natural Gas Conventional Boiler / } \\
\text { Electric Air-Cooled Chiller }\end{array}$ & $\begin{array}{l}\text { Horizontal Closed- } \\
\text { Loop GSHP }\end{array}$ & 11 & 1.7 & $\$ 606,707$ \\
\hline ECIP & Historic Barracks & $30 \mathrm{~g}$ & $\begin{array}{l}\text { Natural Gas Conventional Boiler / } \\
\text { Electric Air-Cooled Chiller }\end{array}$ & Open-Loop GSHP & 11.1 & 1.6 & $\$ 625,167$ \\
\hline ECIP & Historic Barracks & $30 \mathrm{~g}$ & $\begin{array}{l}\text { Natural Gas Conventional Boiler / } \\
\text { Electric Air-Cooled Chiller }\end{array}$ & $\begin{array}{l}\text { Vertical Closed- } \\
\text { Loop GSHP }\end{array}$ & 17 & 1.0 & $\$ 1,070,354$ \\
\hline
\end{tabular}




\begin{tabular}{|c|c|c|c|c|c|c|c|}
\hline $\begin{array}{l}\text { Funding } \\
\text { Source }\end{array}$ & Description & $\begin{array}{c}\text { Group } \\
\text { ID }\end{array}$ & $\begin{array}{c}\text { Current Heating/Cooling } \\
\text { Technology }\end{array}$ & $\begin{array}{l}\text { Retrofit } \\
\text { Technology }\end{array}$ & $\begin{array}{c}\text { Payback } \\
\text { Period } \\
\text { (years) }\end{array}$ & $\begin{array}{c}\text { Savings to } \\
\text { Investment } \\
\text { Ratio }\end{array}$ & $\begin{array}{c}\text { Installed } \\
\text { Capital } \\
\text { Cost }\end{array}$ \\
\hline ECIP & Historic Barracks & $30 \mathrm{~g}$ & $\begin{array}{c}\text { Natural Gas Conventional Boiler / } \\
\text { Electric Package Unit }\end{array}$ & Open-Loop GSHP & 14.7 & 1.2 & $\$ 32,994$ \\
\hline ECIP & WWII Barracks & $30 \mathrm{j}$ & $\begin{array}{l}\text { Natural Gas Conventional Boiler / } \\
\text { Central Chilled Water with AHU }\end{array}$ & Open-Loop GSHP & 21.1 & 1.1 & $\$ 567,845$ \\
\hline ECIP & WWII Barracks & $30 \mathrm{j}$ & $\begin{array}{l}\text { Natural Gas Conventional Boiler / } \\
\text { Electric Air-Cooled Chiller }\end{array}$ & $\begin{array}{l}\text { Horizontal Closed- } \\
\text { Loop GSHP }\end{array}$ & 13.3 & 1.3 & $\$ 173,288$ \\
\hline ECIP & WWII Barracks & $30 \mathrm{j}$ & $\begin{array}{l}\text { Natural Gas Conventional Boiler / } \\
\text { Electric Air-Cooled Chiller }\end{array}$ & Open-Loop GSHP & 10.1 & 1.7 & $\$ 123,282$ \\
\hline UESC & WWII Barracks & $30 \mathrm{j}$ & $\begin{array}{l}\text { Natural Gas Conventional Boiler / } \\
\text { Electric Air-Cooled Chiller }\end{array}$ & Open-Loop GSHP & 15.3 & 1.0 & $\$ 106,278$ \\
\hline ECIP & $\begin{array}{l}\text { Small Vehicle } \\
\text { Maintenance }\end{array}$ & $50 \mathrm{c}$ & $\begin{array}{l}\text { Natural Gas Conventional Boiler / } \\
\text { Electric Air-Cooled Chiller }\end{array}$ & $\begin{array}{l}\text { Horizontal Closed- } \\
\text { Loop GSHP }\end{array}$ & 15.1 & 1.1 & $\$ 404,052$ \\
\hline ECIP & $\begin{array}{l}\text { Medium Vehicle } \\
\text { Maintenance }\end{array}$ & $50 \mathrm{~d}$ & $\begin{array}{l}\text { Natural Gas Conventional Boiler / } \\
\text { Electric Air-Cooled Chiller }\end{array}$ & Open-Loop GSHP & 14.8 & 1.2 & $\$ 530,299$ \\
\hline ECIP & $\begin{array}{l}\text { Medium Vehicle } \\
\text { Maintenance }\end{array}$ & $50 \mathrm{~d}$ & $\begin{array}{c}\text { Natural Gas Floor-Based Radiant } \\
\text { Heating System / Electric Air- } \\
\text { Cooled Chiller } \\
\end{array}$ & Open-Loop GSHP & 16.8 & 1.1 & $\$ 530,299$ \\
\hline ECIP & $\begin{array}{l}\text { Small Older Vehicle } \\
\text { Maintenance }\end{array}$ & $50 \mathrm{e}$ & $\begin{array}{l}\text { Natural Gas Conventional Furnace } \\
\text { / Electric Package Unit }\end{array}$ & $\begin{array}{l}\text { Horizontal Closed- } \\
\text { Loop GSHP }\end{array}$ & 10.2 & 1.7 & $\$ 2,432,602$ \\
\hline UESC & $\begin{array}{l}\text { Small Older Vehicle } \\
\text { Maintenance }\end{array}$ & $50 \mathrm{e}$ & $\begin{array}{l}\text { Natural Gas Conventional Furnace } \\
\text { / Electric Package Unit }\end{array}$ & $\begin{array}{l}\text { Horizontal Closed- } \\
\text { Loop GSHP }\end{array}$ & 11.8 & 1.4 & $\$ 2,097,071$ \\
\hline ECIP & $\begin{array}{l}\text { Small Older Vehicle } \\
\text { Maintenance }\end{array}$ & $50 \mathrm{e}$ & $\begin{array}{c}\text { Natural Gas Conventional Furnace } \\
\text { / Electric Package Unit }\end{array}$ & Open-Loop GSHP & 10.8 & 1.6 & $\$ 2,463,622$ \\
\hline UESC & $\begin{array}{l}\text { Small Older Vehicle } \\
\text { Maintenance }\end{array}$ & $50 \mathrm{e}$ & $\begin{array}{c}\text { Natural Gas Conventional Furnace } \\
\text { / Electric Package Unit }\end{array}$ & Open-Loop GSHP & 13.1 & 1.2 & $\$ 2,123,812$ \\
\hline ECIP & $\begin{array}{l}\text { Med Older Vehicle } \\
\text { Maintenance }\end{array}$ & $50 \mathrm{f}$ & $\begin{array}{l}\text { Central Hot Water with AHU / } \\
\text { Central Chilled Water with AHU }\end{array}$ & $\begin{array}{l}\text { Horizontal Closed- } \\
\text { Loop GSHP }\end{array}$ & 15.3 & 1.6 & $\$ 441,076$ \\
\hline UESC & $\begin{array}{l}\text { Med Older Vehicle } \\
\text { Maintenance }\end{array}$ & $50 f$ & $\begin{array}{l}\text { Central Hot Water with AHU / } \\
\text { Central Chilled Water with AHU }\end{array}$ & $\begin{array}{l}\text { Horizontal Closed- } \\
\text { Loop GSHP }\end{array}$ & 12.1 & 1.4 & $\$ 380,238$ \\
\hline ECIP & $\begin{array}{l}\text { Med Older Vehicle } \\
\text { Maintenance }\end{array}$ & $50 f$ & $\begin{array}{l}\text { Central Hot Water with AHU / } \\
\text { Central Chilled Water with AHU }\end{array}$ & Open-Loop GSHP & 10 & 2.4 & $\$ 298,085$ \\
\hline UESC & $\begin{array}{l}\text { Med Older Vehicle } \\
\text { Maintenance }\end{array}$ & $50 f$ & $\begin{array}{l}\text { Central Hot Water with AHU / } \\
\text { Central Chilled Water with AHU }\end{array}$ & Open-Loop GSHP & 8.5 & 1.9 & $\$ 256,969$ \\
\hline ECIP & $\begin{array}{l}\text { Med Older Vehicle } \\
\text { Maintenance }\end{array}$ & $50 f$ & $\begin{array}{l}\text { Natural Gas Conventional Furnace } \\
\text { / Electric Air-Cooled Chiller }\end{array}$ & $\begin{array}{l}\text { Horizontal Closed- } \\
\text { Loop GSHP }\end{array}$ & 10.6 & 1.7 & $\$ 1,220,035$ \\
\hline UESC & $\begin{array}{l}\text { Med Older Vehicle } \\
\text { Maintenance }\end{array}$ & $50 f$ & $\begin{array}{l}\text { Natural Gas Conventional Furnace } \\
\text { / Electric Air-Cooled Chiller }\end{array}$ & $\begin{array}{l}\text { Horizontal Closed- } \\
\text { Loop GSHP }\end{array}$ & 11.2 & 1.4 & $\$ 1,051,754$ \\
\hline ECIP & $\begin{array}{l}\text { Med Older Vehicle } \\
\text { Maintenance }\end{array}$ & $50 f$ & $\begin{array}{l}\text { Natural Gas Conventional Furnace } \\
\text { / Electric Air-Cooled Chiller }\end{array}$ & Open-Loop GSHP & 7 & 2.6 & $\$ 825,944$ \\
\hline UESC & $\begin{array}{l}\text { Med Older Vehicle } \\
\text { Maintenance }\end{array}$ & $50 \mathrm{f}$ & $\begin{array}{l}\text { Natural Gas Conventional Furnace } \\
\text { / Electric Air-Cooled Chiller }\end{array}$ & Open-Loop GSHP & 7.9 & 2 & $\$ 712,021$ \\
\hline ECIP & $\begin{array}{l}\text { Med Older Vehicle } \\
\text { Maintenance }\end{array}$ & $50 f$ & $\begin{array}{c}\text { Natural Gas Conventional Furnace } \\
\text { / Electric Package Unit }\end{array}$ & $\begin{array}{l}\text { Horizontal Closed- } \\
\text { Loop GSHP }\end{array}$ & 12.5 & 1.4 & $\$ 87,520$ \\
\hline UESC & $\begin{array}{l}\text { Med Older Vehicle } \\
\text { Maintenance }\end{array}$ & $50 f$ & $\begin{array}{l}\text { Natural Gas Conventional Furnace } \\
\text { / Electric Package Unit }\end{array}$ & $\begin{array}{l}\text { Horizontal Closed- } \\
\text { Loop GSHP }\end{array}$ & 11.9 & 1.3 & $\$ 75,449$ \\
\hline ECIP & $\begin{array}{l}\text { Med Older Vehicle } \\
\text { Maintenance }\end{array}$ & $50 f$ & $\begin{array}{c}\text { Natural Gas Conventional Furnace } \\
\text { / Electric Package Unit }\end{array}$ & Open-Loop GSHP & 8.1 & 2.2 & $\$ 59,250$ \\
\hline UESC & $\begin{array}{l}\text { Med Older Vehicle } \\
\text { Maintenance }\end{array}$ & $50 \mathrm{f}$ & $\begin{array}{c}\text { Natural Gas Conventional Furnace } \\
\text { / Electric Package Unit }\end{array}$ & Open-Loop GSHP & 8.4 & 1.9 & $\$ 51,078$ \\
\hline
\end{tabular}




\begin{tabular}{|c|c|c|c|c|c|c|c|}
\hline $\begin{array}{l}\text { Funding } \\
\text { Source }\end{array}$ & Description & $\begin{array}{l}\text { Group } \\
\text { ID }\end{array}$ & $\begin{array}{c}\text { Current Heating/Cooling } \\
\text { Technology }\end{array}$ & $\begin{array}{l}\text { Retrofit } \\
\text { Technology }\end{array}$ & $\begin{array}{c}\text { Payback } \\
\text { Period } \\
\text { (years) }\end{array}$ & $\begin{array}{l}\text { Savings to } \\
\text { Investment } \\
\text { Ratio }\end{array}$ & $\begin{array}{l}\text { Installed } \\
\text { Capital } \\
\text { Cost }\end{array}$ \\
\hline ECIP & Police / Fire & $60 \mathrm{~b}$ & $\begin{array}{l}\text { Natural Gas Conventional Furnace } \\
\text { / Electric Air-Cooled Chiller }\end{array}$ & $\begin{array}{l}\text { Horizontal Closed- } \\
\text { Loop GSHP }\end{array}$ & 17 & 1.0 & $\$ 1,082,960$ \\
\hline ECIP & Police / Fire & $60 \mathrm{~b}$ & $\begin{array}{l}\text { Natural Gas Conventional Furnace } \\
\text { / Electric Air-Cooled Chiller }\end{array}$ & Open-Loop GSHP & 13 & 1.3 & $\$ 762,625$ \\
\hline ECIP & $\begin{array}{l}\text { Small Exchange } \\
\text { Facilities }\end{array}$ & $60 \mathrm{c}$ & $\begin{array}{l}\text { Natural Gas Conventional Boiler / } \\
\text { Electric Air-Cooled Chiller }\end{array}$ & $\begin{array}{l}\text { Horizontal Closed- } \\
\text { Loop GSHP }\end{array}$ & 7.1 & 2.2 & $\$ 358,397$ \\
\hline ECIP & $\begin{array}{l}\text { Small Exchange } \\
\text { Facilities }\end{array}$ & $60 \mathrm{c}$ & $\begin{array}{l}\text { Natural Gas Conventional Boiler / } \\
\text { Electric Air-Cooled Chiller }\end{array}$ & Open-Loop GSHP & 7.2 & 2.2 & $\$ 326,701$ \\
\hline ECIP & $\begin{array}{l}\text { Small Exchange } \\
\text { Facilities }\end{array}$ & $60 \mathrm{c}$ & $\begin{array}{l}\text { Natural Gas Conventional Boiler / } \\
\text { Electric Air-Cooled Chiller }\end{array}$ & $\begin{array}{l}\text { Vertical Closed- } \\
\text { Loop GSHP }\end{array}$ & 13.1 & 1.2 & $\$ 685,391$ \\
\hline ECIP & $\begin{array}{l}\text { Small Exchange } \\
\text { Facilities }\end{array}$ & $60 \mathrm{c}$ & $\begin{array}{c}\text { Natural Gas Conventional Boiler / } \\
\text { Electric Package Unit }\end{array}$ & $\begin{array}{l}\text { Horizontal Closed- } \\
\text { Loop GSHP }\end{array}$ & 8.6 & 1.8 & $\$ 42,794$ \\
\hline ECIP & $\begin{array}{l}\text { Small Exchange } \\
\text { Facilities }\end{array}$ & $60 \mathrm{c}$ & $\begin{array}{c}\text { Natural Gas Conventional Boiler / } \\
\text { Electric Package Unit }\end{array}$ & Open-Loop GSHP & 8.9 & 1.8 & $\$ 39,009$ \\
\hline ECIP & $\begin{array}{l}\text { Small Exchange } \\
\text { Facilities }\end{array}$ & $60 \mathrm{c}$ & $\begin{array}{c}\text { Natural Gas Conventional Boiler / } \\
\text { Electric Package Unit }\end{array}$ & $\begin{array}{l}\text { Vertical Closed- } \\
\text { Loop GSHP }\end{array}$ & 15.6 & 1.0 & $\$ 81,838$ \\
\hline ECIP & $\begin{array}{l}\text { Rec Centers - club } \\
\text { house }\end{array}$ & $80 \mathrm{a}$ & $\begin{array}{l}\text { Natural Gas Conventional Boiler / } \\
\text { Electric Air-Cooled Chiller }\end{array}$ & $\begin{array}{l}\text { Horizontal Closed- } \\
\text { Loop GSHP }\end{array}$ & 11.3 & 1.4 & $\$ 1,181,946$ \\
\hline ECIP & Museum / MWR & $80 \mathrm{~d}$ & $\begin{array}{l}\text { Natural Gas Conventional Boiler / } \\
\text { Electric Air-Cooled Chiller }\end{array}$ & $\begin{array}{l}\text { Horizontal Closed- } \\
\text { Loop GSHP }\end{array}$ & 16.3 & 1.0 & $\$ 1,197,282$ \\
\hline
\end{tabular}




\section{APPENDIX E}

Analysis of Solar Opportunities 
Renewable Energy Opportunities at Fort Sill, Oklahoma

Pacific Northwest National Laboratory, March 2011 


\section{Appendix E: Analysis of Solar Opportunities}

\section{Solar Technology}

There is a wide range of solar technologies and applications available for energy generation. Solar technologies can be classified by the specific technique used for converting solar energy into useful energy. Solar energy is unique in that the sun's energy, or insolation, can be captured to provide electrical energy, heating energy (solar thermal), or a combination of both.

Solar technologies can be further categorized by their scale. Large-scale solar projects can easily exceed 1-MW and can have hundreds of collectors. Smaller-scale projects, often at the building level, are also possible and may be more desirable because of land area limitations, aesthetics considerations, or for energy security. Certain solar technologies, such as photovoltaic (PV), can be either large-scale or small-scale, while technologies such as solar hot water heating are only found at the building level.

\section{Solar Electric}

Solar electric collectors are either PV arrays or concentrating solar arrays. There are three major PV array subcategories, as follows:

- Flat Panel. Arrays of PV modules mounted on racks either at ground level or on rooftops at a fixed angle. Generally, this angle is equal to the location's latitude. On rooftops, the angle can be the angle of the rooftop or an angle set by specialized mounting brackets attached to the roof. In addition, there are two common PV technologies on the market, silicon PV and cadmium telluride (CdTe) "thin film" PV. Other PV technologies such as gallium arsenide (GaAs) and copper-indium selenide (CIGS) are available, but uncommon.

- Axis-Tracking. PV arrays can be mounted on an assembly that moves throughout the day to keep the array positioned at an optimum angle to maximize the captured sunlight (Figure E-1). An axis-tracking system can be either single- or dual-axis in nature. A single-axis tracking system typically has a fixed tilt and the system follows the sun's trajectory across the sky. These systems are able to collect more sunlight than nontracking systems. A dual-axis tracking system allows the panels to rotate along two axes, thereby truly maximizing the panel's ability to harvest solar energy. However, these systems are considerably more complex and impose additional operations and maintenance $(\mathrm{O} \& \mathrm{M})$ costs than flat panel assemblies. 


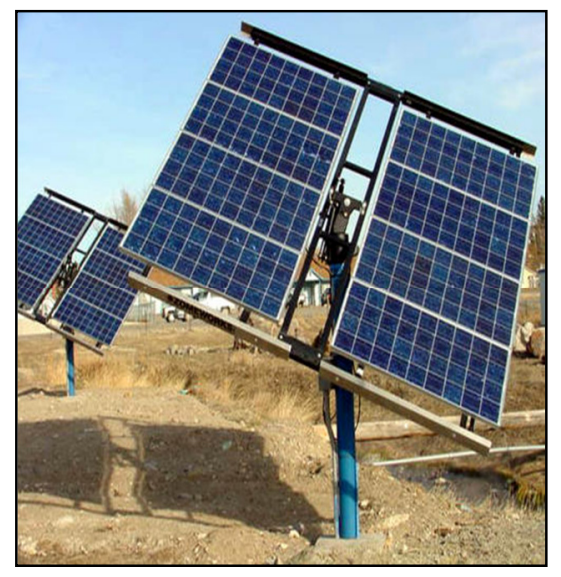

Figure E-1: Axis-Tracking PV Array

Concentrating solar power (CSP) systems use mirrors, lenses, and other optical devices to concentrate the sun's energy. There are four primary configurations of thermal CSP systems:

- Solar Dish. A solar dish system employs an engine that is able to harvest thermal energy to generate electricity. These dual-axis tracking systems use dish-like concentrators to focus thermal energy on a point where a heat engine is mounted. Stirling engines are frequently used in solar dish applications. Most systems are several kilowatts to tens of kilowatts in size.

- Solar Power Tower. A solar power tower system uses very large arrays of mirrors, or heliostats, to concentrate the sun's energy on a central receiver tower to produce steam that drives a generator. Thermal storage allows the system to store thermal energy for use at dusk and into the evening. Most existing or planned commercial solar power tower plants are larger than 10-MW.

- Solar Trough. When used for power generation, these large arrays concentrate the sun's energy onto a pipe containing a liquid that is used to generate steam that drives a generator. These systems always employ single-axis tracking mirrors or reflectors orientated along the north-south axis and are highly sensitive to the slope of the ground as a result of the need to pump the liquid through the collector tubes. Cogeneration and thermal storage are options for this technology as well. Solar trough plants are 40-MW or larger.

- $\quad$ Concentrating $P V$. In a CPV system, mirrors and/or lenses focus sunlight onto a small area of PV material. Typically, this PV material is more sophisticated and expensive than the PV material used in conventional solar cells. However, these advanced PV cells are also more efficient and are capable of absorbing insolation levels equivalent to dozens to hundreds of suns. While there are several commercial, small-scale CPV arrays and a handful of medium-scale utility demonstration projects, this technology is still too immature to be considered in this analysis.

Thermal CSP plants are still in various stages of development. While thermal CSP plants are somewhat unproven compared to traditional PV plants, they have the potential to deliver large quantities of energy at competitive prices. 
Thermal concentrating power systems were not considered for this assessment because the available direct normal insolation is less than the $6.75 \mathrm{kWh} / \mathrm{m}^{2} /$ day threshold typically cited for CSP feasibility (DOE 2010). Direct normal insolation is a subset of the total insolation levels that excludes the indirect (diffuse) insolation, which is reflected from clouds or the ground, because this insolation cannot be concentrated. Fort Sill has an average direct normal insolation level of $5.46 \mathrm{kWh} / \mathrm{m}^{2} /$ day (NASA 2010), which is below the $6.75 \mathrm{kWh} / \mathrm{m}^{2} /$ day target.

\section{Solar Thermal}

Rather than electricity as the end product, solar energy can also be used to directly heat air in the form of transpired solar collectors (i.e., solar walls), water that is used for space heating, or water that is used for service hot water (SHW) or swimming pools. These solar energy systems can be cost-competitive even when PV is not. However, solar thermal projects do not count towards the EPAct mandate and therefore are excluded from this analysis.

\section{Solar Analysis Approach}

The analytic approach for the solar energy assessment consists of the following steps:

$\checkmark$ Identify solar potential-Use established sources to determine seasonal and annual solar radiation for the site.

$\checkmark$ Determine utility perspective-Obtain electric rate tariff information, evaluate state and local regulations, and identify grants, incentives, and other support.

$\checkmark \quad$ Identify potential development areas - Study existing electrical transmission system and identify installation-specific sites and potential users of generated energy.

$\checkmark$ Determine applicable solar technology - Evaluate solar electric technologies including both large-scale (approximately 1+ MW) applications, such as a ground-mounted PV array, and small-scale (kW-scale) applications, such as roof-mounted PV systems.

$\checkmark$ Develop project economics-Determine project capital investment requirements, project O\&M costs, and estimate economic value of expected electric production based on selected solar technology and market prices

\section{Solar Resource Characterization}

Oklahoma experiences a wide range of insolation ranging from 4.5 to over $6.0 \mathrm{kWh} / \mathrm{m}^{2} / \mathrm{day}$. From a resource perspective, Fort Sill is positioned in a region of moderate solar potential. Figure E-2 displays the annual mean horizontal insolation on a south facing, latitude-tilted collector for the region. 


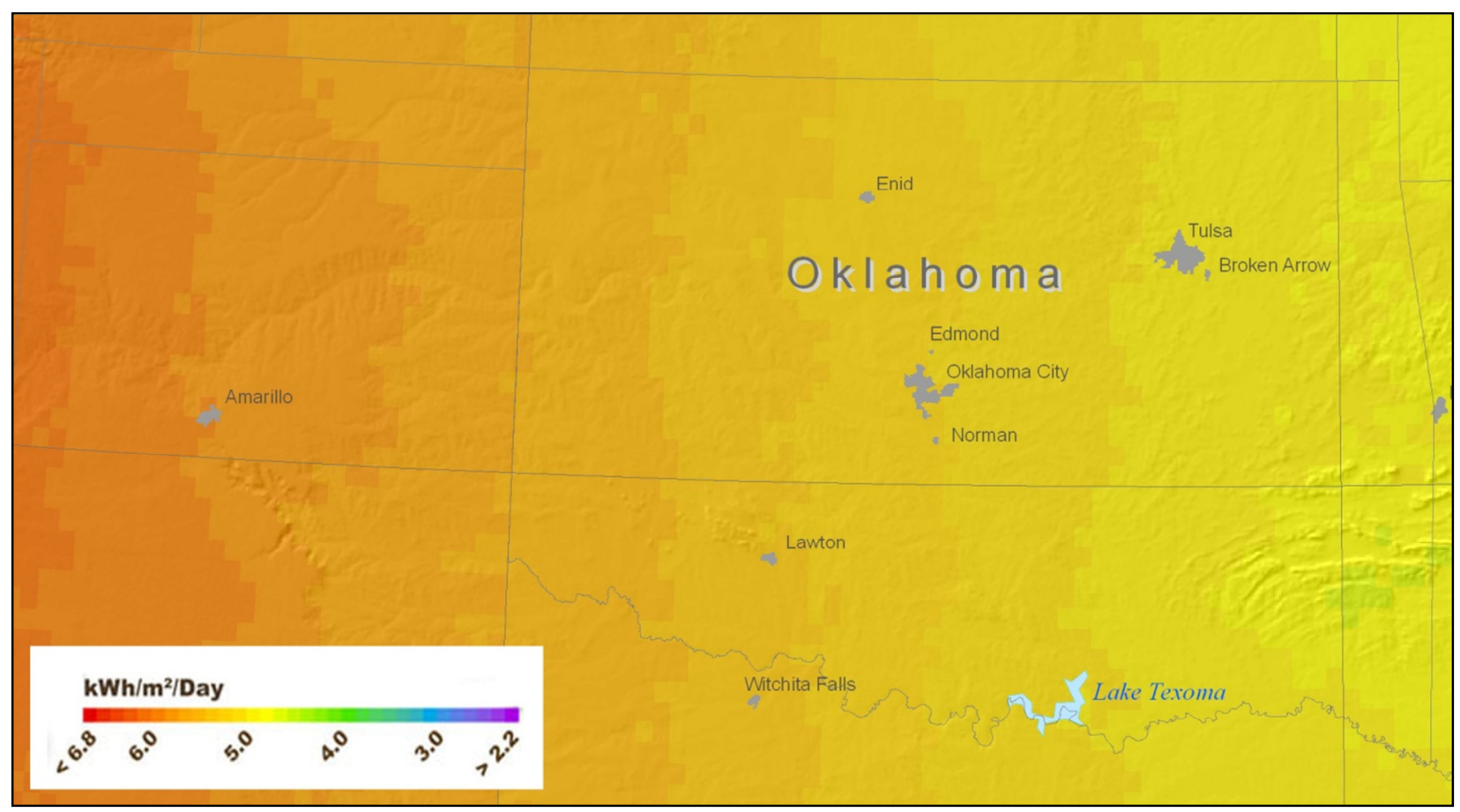

Figure E-2: Solar Insolation Levels (NREL 2008)

The solar resource potential was estimated using the solar potential estimates in National Aeronautics and Space Administration's (NASA) Surface meteorology and Solar Energy (SSE) data and Natural Resources Canada's RETScreen analysis software. The SSE data set is a continuous and consistent 10-year global climatology of insolation and meteorology data on a $1^{\circ}$ by $1^{\circ}$ grid system. Although the SSE data within a particular grid cell are not necessarily representative of a particular microclimate within the cell, the data are considered to be the average over the entire area of the cell. That estimate should be sufficiently accurate for preliminary feasibility studies of new renewable energy projects.

Table E-1 shows the average solar insolation data for several different surface orientations. Average monthly insolation values are provided in $\mathrm{kWh} / \mathrm{m}^{2} /$ day for the following conditions:

- Tilt 0 - Collector installed at a $0^{\circ}$ tilt (i.e., on a flat surface such as a roof).

- Tilt (lat-15) - A tilt of latitude minus $15^{\circ}$ would favor energy production in the summer when the sun is higher.

- Tilt lat - Tilting a PV array at an angle equal to the latitude is a generally accepted way to optimize annual electricity production.

- Tilt (lat+15) - A tilt of latitude plus $15^{\circ}$ would favor energy production in the winter when the sun is lower.

- Tilt 90 - Collector installed against a vertical surface (i.e., a wall).

- Single-Axis Tracking - A collector capable of tracking the sun's azimuth angle over the course of the day. 
Table E-1: Monthly Averaged Insolation Incident on a South-Facing Tilted Surface at Fort Sill $\left(\mathrm{kWh} / \mathrm{m}^{2} / \mathrm{day}\right)$

\begin{tabular}{|c|c|c|c|c|c|c|c|c|c|c|c|c|c||}
\hline & Jan & Feb & Mar & Apr & May & Jun & Jul & Aug & Sep & Oct & Nov & Dec & $\begin{array}{c}\text { Annual } \\
\text { Average }\end{array}$ \\
\hline Tilt 0 & 2.8 & 3.5 & 4.6 & 5.7 & 6.2 & 6.8 & 6.9 & 6.3 & 5.0 & 4.0 & 2.9 & 2.5 & 4.8 \\
\hline Tilt 20 $^{\circ}$ & 3.7 & 4.3 & 5.1 & 5.9 & 6.1 & 6.5 & 6.7 & 6.4 & 5.5 & 4.8 & 3.8 & 3.4 & 5.2 \\
\hline Tilt 35 $^{\circ}$ & 4.2 & 4.6 & 5.3 & 5.7 & 5.7 & 6.0 & 6.2 & 6.1 & 5.5 & 5.1 & 4.3 & 3.9 & 5.2 \\
\hline Tilt 50 $^{\circ}$ & 4.5 & 4.7 & 5.1 & 5.3 & 5.0 & 5.1 & 5.4 & 5.5 & 5.3 & 5.2 & 4.5 & 4.2 & 5.0 \\
\hline $\begin{array}{c}\text { Single- } \\
\text { Axis } \\
\text { Tracking }\end{array}$ & 5.1 & 5.5 & 6.7 & 7.2 & 7.4 & 7.8 & 8.2 & 8.1 & 7.0 & 6.6 & 5.1 & 4.7 & 6.6 \\
\hline
\end{tabular}

As shown, a flat collector tilted at $35^{\circ}$ (the site's latitude) has an average yearly solar potential of $5.2 \mathrm{kWh}_{\text {solar }} / \mathrm{m}^{2} /$ day. A single-axis tracking PV array will receive $6.6 \mathrm{kWh}_{\text {solar }} / \mathrm{m}^{2} /$ day of incident solar radiation. Figure E-3 shows this incident solar radiation on a flat roof surface $\left(0^{\circ}\right.$ tilt), a fixed array (latitude tilt), and a single-axis tracking array at Fort Sill.

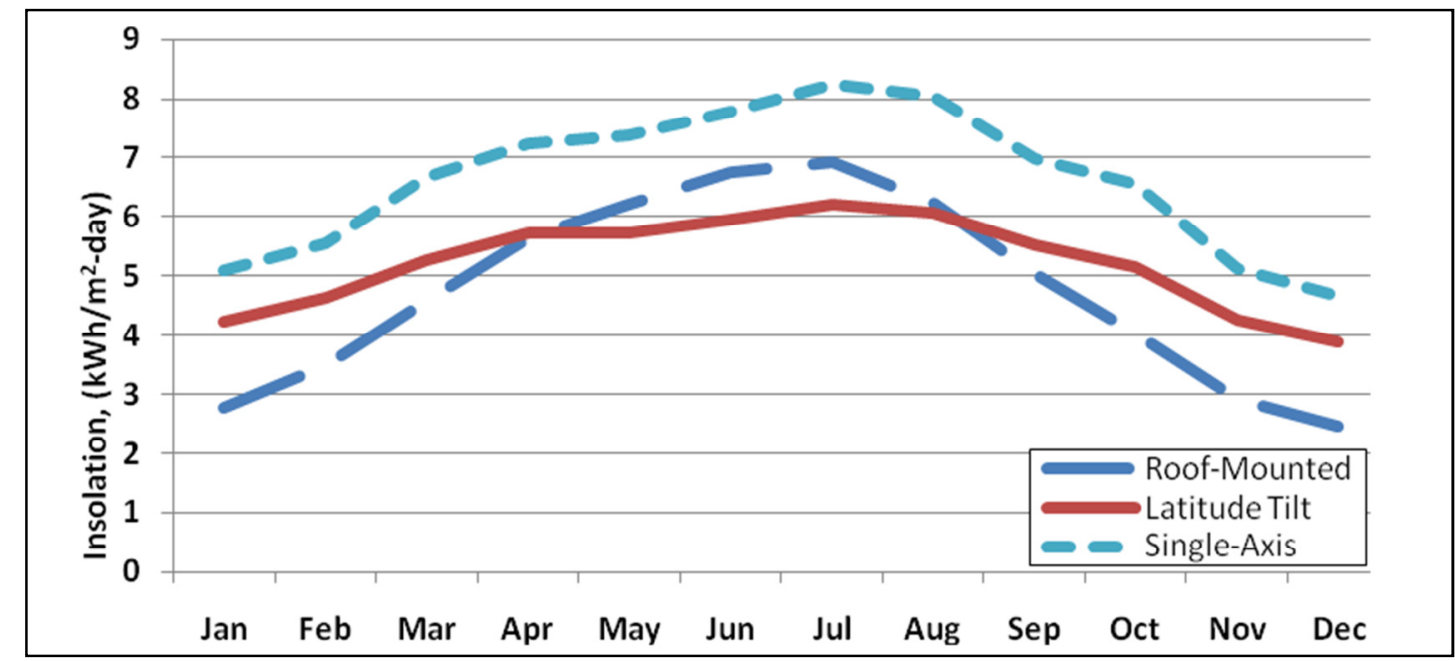

Figure E-3: Average Daily Insolation at Fort Sill

\section{Siting Considerations for PV Technologies}

Compared to most renewable energy technologies, PV panels have a fair degree of siting flexibility. As previously mentioned, an array can be mounted on the ground or upon existing buildings and structures. A potential site needs to be free of any objects, such as trees or buildings, which may cast a shadow on the array. Also, the system will require an inverter to convert the DC output power into AC power. For projects $25-\mathrm{kW}$ or larger, it is common to use multiple inverters to optimize the system's efficiency as well as provide redundancy.

A typical 1-kW PV array may range in size from 8 to $9 \mathrm{~m}^{2}$; however, a larger array requires access space as well as spacing between the rows of panels to avoid self-shading, and will subsequently require a greater amount of space per installed kW. For example, a $30-\mathrm{kW}$ array would likely require $550 \mathrm{~m}^{2}$, and a $100-\mathrm{kW}$ array may require nearly $2,000 \mathrm{~m}^{2}$, assuming that the PV array occupies 50\% of the space. Panels mounted on slanted roofs can usually be more tightly grouped because of a decrease in self-shading potential. In addition, large arrays can 
produce considerable amounts of energy and require siting near existing high voltage power lines.

Fort Sill appears to have a moderate amount of open space for ground-mounted PV. Possible sites that appear to have sufficient open space and are relativity free from shading include:

- The empty lot at the intersection of Wilson Street and Mow-Way Road

- The empty field northwest of Randolph Road and Hand Road,

- On several of the empty fields along Boundary Road,

- On suitable portions of rangeland.

There are additional spaces spread throughout Fort Sill that might be suitable for a PV array. The terrain is generally flat, but is frequently wooded or hilly. The primary disadvantage of these areas is the increased expense of land preparation for a PV array. The availability of space near the cantonment area suggests that considering more remote areas for large-scale PV deployment may not be necessary.

\section{Findings: Solar Electric Production}

Solar conversion is an inefficient process; typical PV cells have a conversion efficiency ranging from $10 \%$ to $20 \%$. Taking into account the annual solar potential and the efficiency of a typical PV system, each fixed-angle, latitude-tilted MW of installed PV would be expected to produce 1,629 $\mathrm{MWh}_{\text {electric }}$ at Fort Sill. The system would have a capacity factor of $18.6 \%$.

A single-axis tracking PV array can produce significantly more electricity than a stationary PV array, resulting in a higher output per unit surface area, and has a much flatter energy output profile during the day. The tracking racks increase the cost of installation by approximately $\$ 1$ to $\$ 2$ per installed watt. A 1-MW single-axis tracking array would produce $2,063 \mathrm{MWh}_{\text {electric }}$ annually at Fort Sill. The system would have a capacity factor of $23.5 \%$.

A building-mounted PV array installed on a flat roof at Fort Sill would be expected to produce between 1,490 to 1,517 MWhelectric annually per 1-MW of installed capacity depending on the PV technology. The system would have a capacity factor of $17.0 \%$ to $17.3 \%$, depending on the PV technology.

A summary of the solar electric production information can be found in Table E-2. 
Table E-2: Solar Electric Production by System Type at Fort Sill

\begin{tabular}{|c|c|c|c|c|c|}
\hline System Type & $\begin{array}{c}\text { Assumed PV } \\
\text { Module } \\
\text { Efficiency } \\
\end{array}$ & $\begin{array}{l}\text { Solar Insolation, } \\
\mathbf{k W h}_{\text {(solar) }} / \mathbf{m}^{2} / \mathbf{y r}\end{array}$ & $\begin{array}{c}\text { Electric } \\
\text { Production, } \\
\mathbf{M W h}_{\text {(electric) }} / \mathbf{y r}\end{array}$ & $\begin{array}{c}\text { Specific } \\
\text { Yield, } \\
\mathbf{k W h} / \mathbf{m}^{2}\end{array}$ & $\begin{array}{l}\text { Capacity } \\
\text { Factor, \% }\end{array}$ \\
\hline $\begin{array}{c}\text { 1-MW South-Facing, } \\
\text { Latitude Tilt }\end{array}$ & $18.7 \%$ & 1,900 & 1,629 & 301 & 18.6 \\
\hline $\begin{array}{c}\text { 1-MW Single-Axis } \\
\text { Tracking }\end{array}$ & $18.7 \%$ & 2,420 & 2,062 & 382 & 23.5 \\
\hline $\begin{array}{c}\text { 1-MW Roof Mounted } \\
\text { Silicon PV }\end{array}$ & $18.7 \%$ & 1,740 & 1,490 & 276 & 17.0 \\
\hline $\begin{array}{l}\text { 1-MW Roof Mounted } \\
\text { CdTe Thin Film PV }\end{array}$ & $11.0 \%$ & 1,740 & 1,517 & 182 & 17.3 \\
\hline
\end{tabular}

\section{Findings: Solar Project Economics}

Based on current average solar system costs and the projected performance for the various solar system configurations, life-cycle costs were developed for solar technologies at Fort Sill under two funding scenarios:

- Appropriated, using Energy Conservation Investment Program (ECIP) funds, and

- Third-party financing via an independent power producer (IPP).

Cost-effective ECIP projects have savings-to-investment ratio (SIR) values greater than 1.0, while a $10 \%$ internal rate of return (IRR) shows whether the IPP scenario is cost-effective. Third-party financing utilizes a third party to develop, fund, and own the projects under a power purchase agreement (PPA) or other vehicle. The third party, being a private company or utility, could take advantage of tax credits for renewable energy projects and may also sell the renewable energy credits (RECs), which in turn lower the cost required to pay for the electricity. Building-integrated PV can also be developed by a third party to take advantage of government incentives.

Solar PV arrays are generally no larger than several megawatts, and are not capable of providing baseload power because of their intermittent nature. Therefore, PV arrays can typically only displace electricity charges and not power charges. This charge is known as the marginal electric rate. The marginal electric rate at Fort Sill was calculated to be $1.36 \notin / \mathrm{kWh}$.

The analysis assumed an $8.9 \%$ sales tax, a $1.2 \%$ inflation rate, MACRS depreciation, a $6 \%$ state income tax, and a $1.4 \%$ property tax.

At this time, none of the systems considered is cost-competitive. The CdTe thin film array proved to be the most cost-effective, among the systems examined. The primary barrier to costeffective solar array deployment is the remarkably low cost of electricity at Fort Sill. Although several range buildings consume electricity at a different rate, these buildings do not consume enough electricity to allow for large-scale array construction. Moreover, even if a small array were constructed, it would not displace electricity at a value near the breakeven range. A PV array could be constructed on range lands and the electricity may potentially be wheeled back to 
the site. However, all wheeled electricity would displace the low cost electricity. The SIR and simple payback for the ECIP scenario, the cost of electricity at a 10\% IRR for the IPP scenario, and the assumed system costs are shown in Table E-3 for each technology.

Table E-3: Economic Results for Solar Technologies at Fort Sill

\begin{tabular}{|c|c|c|c|c|}
\hline Solar PV System & $\begin{array}{l}\text { Ground-Mounted } \\
\text { Fixed-Tilt PV }\end{array}$ & $\begin{array}{l}\text { Ground-Mounted } \\
\text { Axis-Tracking PV }\end{array}$ & $\begin{array}{l}\text { Roof-Mounted } \\
\text { CdTe PV }\end{array}$ & $\begin{array}{l}\text { Roof-Mounted } \\
\text { Si PV }\end{array}$ \\
\hline $\begin{array}{l}\text { Equipment Cost Assumptions, } \\
\$ / \mathbf{k W}\end{array}$ & 5,625 & 6,625 & 4,000 & 4,500 \\
\hline SIR & 0.0 & 0.0 & 0.0 & 0.0 \\
\hline Simple Payback, yrs & $\mathrm{n} / \mathrm{a}^{*}$ & $\mathrm{n} / \mathrm{a}$ & $\mathrm{n} / \mathrm{a}$ & $\mathrm{n} / \mathrm{a}$ \\
\hline $\begin{array}{l}\text { Cost of Electricity at } 10 \% \text { IRR, } \\
\text { c/kWh }\end{array}$ & 40.40 & 38.11 & 31.22 & 35.60 \\
\hline Variable O\&M, $\notin / \mathbf{k W h}$ & 0.0 & 0.0 & 0.0 & 0.0 \\
\hline Fixed O\&M, \$/net kW & 20 & 33 & 20 & 20 \\
\hline $\begin{array}{l}\text { Federal Energy Tax Credit (a } \\
\text { credit worth a percentage of } \\
\text { the expenditures) }\end{array}$ & $30 \%$ & $30 \%$ & $30 \%$ & $30 \%$ \\
\hline
\end{tabular}

* N/A refers to an indeterminate result

\section{Solar: Next Steps}

Solar energy projects are not cost-effective at this time because of Fort Sill's moderate solar energy resource and current PV capital costs. Although the economics are unfavorable, there is interest at Fort Sill in solar projects, so Fort Sill should continue to monitor the market conditions affecting solar energy, the incentives available, and the installation's energy needs so a project can be reevaluated in the future if conditions change favorably. In addition, Fort Sill is an ideal location to test PV demonstration projects and explore PV integrated microgrid applications.

Advances in PV technology are expected to produce less expensive solar cells, although rising demand for PV may negate some of the potential price drop. Rising energy rates may do the most to tip the scales in favor of solar electric. Probably the most important factor in making solar electric work at a Federal installation is identifying key partners - a private developer, a utility, or both - that can provide funding, capture tax incentives, purchase or market RECs, enter into PPAs, and provide other project support.

\section{Solar Sources of Information}

DOE - U.S. Department of Energy. 1997. Renewable Energy Technology Characterizations December 1997 - Solar Parabolic Trough. TR-109496, Office of Utility Technologies, Energy Efficiency and Renewable Energy, U.S. Department of Energy and Electric Power Research Institute, Inc., Washington, DC. Accessed May 2010 at http://www1.eere.energy.gov/ba/pba/tech_characterizations.html.

DOE - U.S. Department of Energy. 1997. Renewable Energy Technology Characterizations December 1997 - Solar Power Tower. TR-109496, Office of Utility Technologies, Energy 
Efficiency and Renewable Energy, U.S. Department of Energy and Electric Power Research Institute, Inc., Washington, DC. Accessed May 2010 at

http://www1.eere.energy.gov/ba/pba/tech_characterizations.html.

DOE - U.S. Department of Energy. 1997. Renewable Energy Technology Characterizations December 1997 - Solar Dish Engine. TR-109496, Office of Utility Technologies, Energy Efficiency and Renewable Energy, U.S. Department of Energy and Electric Power Research Institute, Inc., Washington, DC. Accessed May 2010 at http://www1.eere.energy.gov/ba/pba/tech_characterizations.html.

DOE - U.S. Department of Energy. 2010. 2008 Solar Technologies Market Report. Solar Energy Technologies Program, U.S. Department of Energy. Washington, DC. Accessed June 2010 at http://www1.eere.energy.gov/solar/pdfs/46025.pdf.

Emerging Energy Research, LTD. 2007. Global Concentrating Solar Power Markets and Strategies, 2007-2020. Emerging Energy Research, LTD., Cambridge, MA.

Minister of Natural Resources Canada. 2008. RETscreen Clean Energy Project Analysis Software. RETScreen International Clean Energy Decision Support Centre, Minister of Natural Resources Canada, Ottawa, Ontario, Canada. Accessed May 2010 at http://www.retscreen.net (last updated March 3, 2010).

NASA - National Aeronautics and Space Administration's Langley Research Center and Atmosphere Science Data Center. 2010. Surface meteorology and Solar Energy. Accessed May 2010 at http://eosweb.larc.nasa.gov/sse (last updated May 4, 2010).

NREL - National Renewable Energy Laboratory. 2008. U.S. Solar Resource Map. Accessed November 2009 at http://www.nrel.gov/gis/solar.html. 


\section{APPENDIX F}

\section{Analysis of Wind Opportunities}


Renewable Energy Opportunities at Fort Sill, Oklahoma

Pacific Northwest National Laboratory, March 2011 


\section{Appendix F: Analysis of Wind Opportunities}

\section{Wind Technology}

There is a vast wind resource in the United States. The American Wind Energy Association states that domestic wind resources, which are economically feasible in at least 46 states, could theoretically supply all of the nation's electricity needs (AWEA 2007). At the current time, however, less than $2 \%$ of the nation's power is generated from wind, though electricity generation from wind power projects continues to increase. In 2008, wind power projects accounted for $42 \%$ of all the new generating capacity installed in the United States, up from $2 \%$ of installed capacity in 2004 (AWEA 2009).

Wind projects, often referred to as wind farms, can be categorized by scale. Large, utility-scale projects tend to be 50-MW and above, with the world's largest single wind farm being in Texas at over 700-MW. Smaller-sized projects (under 50-MW) are often referred to as community wind projects or distributed generation (DG) projects. Community wind projects involve local ownership structures, often with corporate partners taking advantage of the federal production tax credit. DG projects are designed to offset the owner's retail electricity purchases by producing power that is used on-site, with any surplus sold to a commercial utility.

Wind turbines come in many different sizes and configurations. Wind turbines in the U.S. generally employ the Danish configuration - a horizontal-axis, three-bladed rotor, an upwind orientation, and an active yaw system to keep the rotor oriented into the wind.

Utility-scale turbines for bulk power production tend to be $660-\mathrm{kW}$ to $3-\mathrm{MW}$ in size. Hub heights can range from 50 meters (164 feet) to 100 meters ( 328 feet). Industrial turbines for consumer and remote grid production are found in the range of $50-\mathrm{kW}$ to $250-\mathrm{kW}$. Hub heights range between 25 meters ( 80 feet) and 40 meters (131 feet). Residential-scale wind turbines are used for remote power, battery charging, or net-metering generation. These turbines tend to be 400 watts to $50-\mathrm{kW}$. For turbines greater than $1-\mathrm{kW}$, the hub heights range from 12 meters (40 feet) to 36 meters (120 feet).

The land required for a single utility-scale wind turbine is typically 3 acres, including access roads, turbine base, and other equipment. A wind turbine located on a ridgeline in hilly terrain will require less area than one on flat land, as little as 2 acres per MW. The proper spacing of turbines is essential to reduce wake interference and optimize the wind resource. In open flat terrain, a utility-scale wind plant will require a buffer space of about 60 acres per MW of installed capacity.

Although more difficult to finance and lacking in economies of scale, smaller-sized wind generation projects offer some potential benefits over large-scale wind farms:

- A smaller project is often easier to permit and may be less likely to interfere with other land uses (including military missions).

- On-site power generation that is integrated into the site electrical system provides energy security. 
- It may be possible to avoid building a costly substation if a suitably sized power interconnection is located near a promising site for wind turbines.

\section{Wind Analysis Approach}

This study builds off the 2005 DoD assessment with a modified methodology and current cost data.

\section{DoD Assessment Approach}

The DoD Renewables Study (Conover et al. 2004) relied upon wind resource maps developed by the National Renewable Energy Laboratory (NREL), maps developed by independent companies, and PNNL's Wind Energy Resource Atlas of the United States to identify the installations with best potential for commercial-scale wind farms. The DoD analysis used the highest resolution map available for each state to quantify the wind resource on the military land in that state. Over 70 Army and Air Force installations were reviewed with respect to both wind resource and compatibility with the installation's mission. About 20 installations with potential for projects were selected for follow-on detailed assessments. Fort Sill was included in that study.

The study evaluated Fort Sill's wind resource and identified potential development areas by considering mission compatibility, the on-site wind resource, the terrain, transmission access, and environmental and cultural issues. The study also included an economic analysis. Information from this previous study will be referenced in this updated analysis.

\section{Updated Wind Analysis Approach}

For this updated analysis, PNNL used the following approach to analyze the economic potential for wind energy at Fort Sill. More detail on the financing scenarios, generic analytic approach, and economic and other parameters used in this analysis are documented in Appendix A of this report.

(1) Wind resource maps and available on-site data were analyzed.

(2) Existing on-site interconnection and transmission capacity and availability were evaluated.

(3) Local wind developer activity in the area was surveyed to assess potential interest in developing projects.

(4) Turbine model sizes were selected to establish cost and performance parameters.

(5) Total project cost was estimated, including project development, generation equipment, balance of plant construction, interconnection and transmission, operation and maintenance $(\mathrm{O} \& \mathrm{M})$, taxes, and tax credits and other policy incentives.

(6) Economic feasibility was determined utilizing different financing scenarios: independent power producer (IPP) and Energy Conservation Investment Program (ECIP).

(7) Project feasibility was determined and next steps recommended. 


\section{Wind Resource Characterization}

According to industry standards developed as part of the Wind Energy Resource Atlas of the United States, there are seven main classes of wind power, as shown in Table F-1.

Table F-1: Classes of Wind Power Density at 50 Meters

\begin{tabular}{||c|c|c||}
\hline $\begin{array}{c}\text { Wind } \\
\text { Power } \\
\text { Class }\end{array}$ & $\begin{array}{c}\text { Wind Power } \\
\text { Density, } \\
\text { W/m }\end{array}$ & Speed, m/s (mph) \\
\hline $\mathbf{1}$ & $<200$ & $<5.6(12.5)$ \\
\hline $\mathbf{2}$ & $200-300$ & $5.6(12.5)-6.4(14.3)$ \\
\hline $\mathbf{3}$ & $300-400$ & $6.4(14.3)-7.0(15.7)$ \\
\hline $\mathbf{4}$ & $400-500$ & $7.0(15.7)-7.5(16.8)$ \\
\hline $\mathbf{5}$ & $500-600$ & $7.5(16.8)-8.0(17.9)$ \\
\hline $\mathbf{6}$ & $600-800$ & $8.0(17.9)-8.8(19.7)$ \\
\hline $\mathbf{7}$ & $>800$ & $>8.8(19.7)$ \\
\hline
\end{tabular}

A strong Class 3 resource, preferably Class 4, is generally required to achieve an economic project on a large, commercial scale.

In the DoD Renewables Study, the Oklahoma wind resource map consulted was based on 2002 modeling efforts and indicated that Fort Sill mainly had Class 2 wind with large patches of Class 3 wind and small areas of Class 4 wind. This map is shown in Figure F-1 and includes an outline of Fort Sill's property boundary.

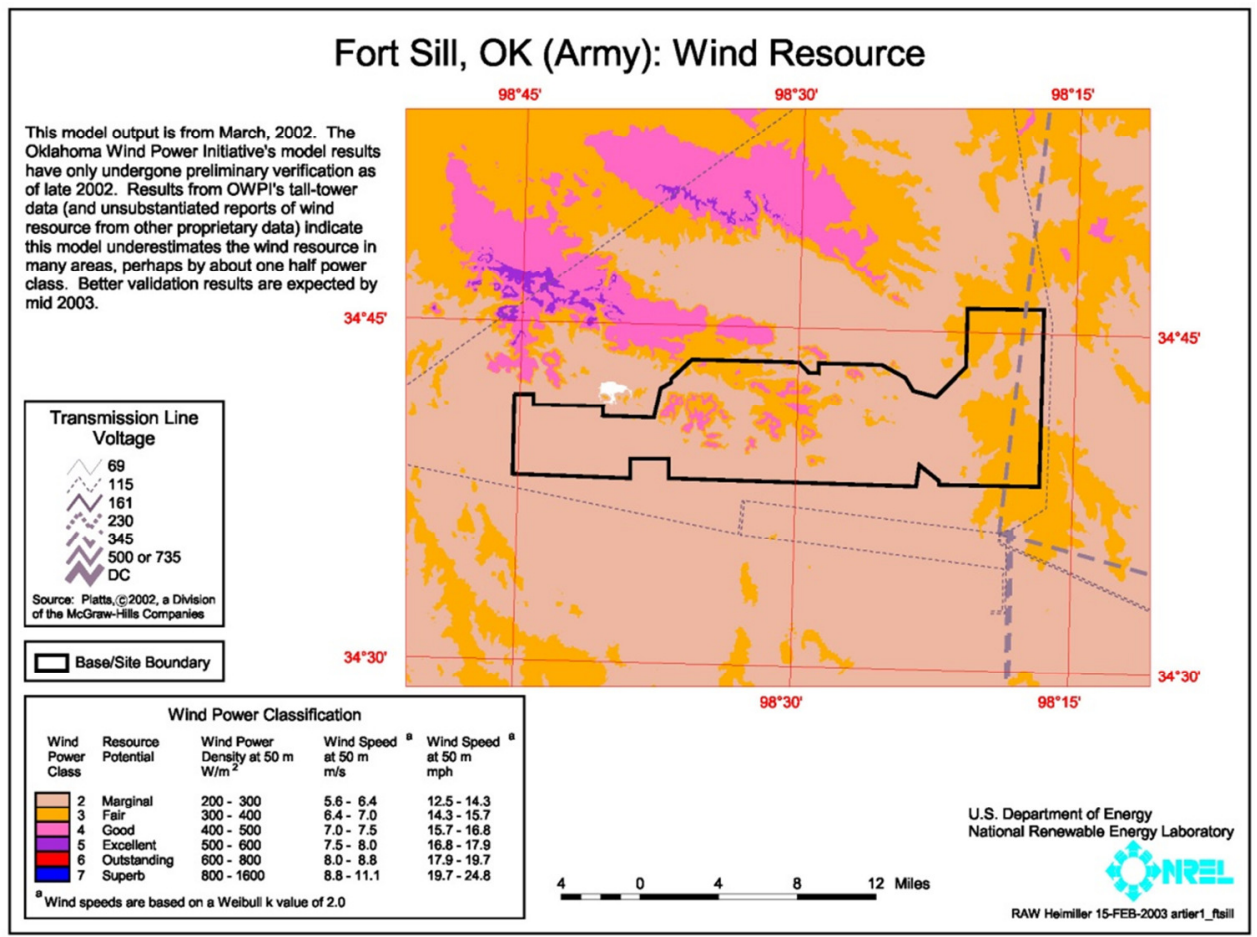

Figure F-1: Oklahoma Wind Resource Map (DOD 2004) 
Subsequent verification and updates to this map have not changed these conclusions. The Oklahoma State University wind resource map shown in Figure F-2 indicates the same wind resource class distribution.

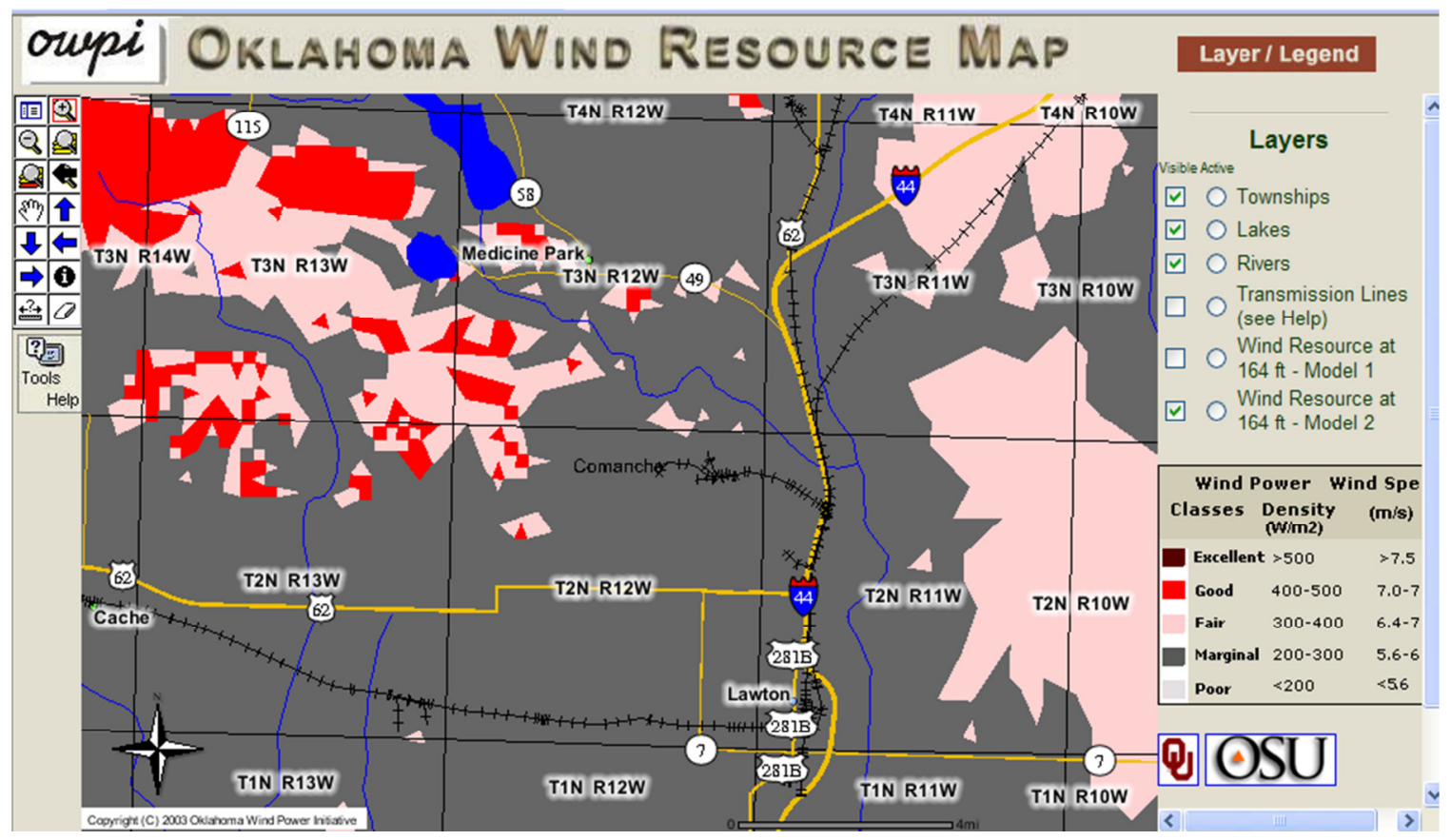

Figure F- 1: Fort Sill OSU Wind Resource Map (OWPI 2010)

To exactly determine an area's wind resource, the installation of a meteorological tower (met tower) is required to collect site-specific wind data.

In December 2003, a 50-m met tower was installed at Fort Sill and collected 9 months of data. The average wind speed measured at the site was $7.2 \mathrm{~m} / \mathrm{s}$ at $50 \mathrm{~m}(16.1 \mathrm{mph})$. Based on this collected data and correlation calculations with other wind data for the area, the DoD Renewables Study team estimated the long-term, hub-height adjusted annual average wind speed to be $7.07 \mathrm{~m} / \mathrm{s}$ at $65 \mathrm{~m}(15.8 \mathrm{mph})$.

The met tower was sited in the hill area between the northern boundary of the installation and Deer Creek Canyon Road. The met tower is approximately 2,400 feet from the border at Latitude 34.7181 N, Longitude -98.5461 W (NAD27). This is an area with Class 3 and 4 winds.

As a point of reference, the online windNAVIGATOR wind mapping tool from AWS Truewind was consulted. At 60 meters above ground, the most similar hub height to the calculated wind speed for which the tool provides data, the average annual wind speed found in the same area is $7.28 \mathrm{~m} / \mathrm{s}$ (AWS Truewind 2010).

Table F-2 summarizes Fort Sill's wind resource according to the available data sources. 
Table F-2: Summary of Wind Resource Data

\begin{tabular}{|c|l|l||}
\hline Location & \multicolumn{1}{|c|}{ Source } & \multicolumn{1}{c|}{ Wind Speed } \\
\hline \multirow{4}{*}{ Fort Sill } & Wind Resource Maps & $\begin{array}{l}\text { Classes 2,3, and } 4 \text { (wind speeds } \\
\text { up to } 7.5 \mathrm{~m} / \mathrm{s} \text { at } 50 \mathrm{~m} \text { ) }\end{array}$ \\
\cline { 2 - 3 } & Met Tower Data & $7.07 \mathrm{~m} / \mathrm{s}$ at $65 \mathrm{~m}$ \\
\cline { 2 - 3 } & AWS Truewind's windNavigator tool & $7.28 \mathrm{~m} / \mathrm{s}$ at $60 \mathrm{~m}$ \\
\hline
\end{tabular}

\section{Siting Considerations}

After wind resource availability, the primary siting consideration for grid-connected wind projects is transmission availability and the capacity of those lines. Projects need to be located within approximately 1 mile of existing transmission lines, or new lines will need to be constructed at considerable cost.

The DoD Renewables Study identified a 138 kV transmission line owned by Western Farmers Electric Cooperative within Fort Sill's boundary. This is an adequate sized line for a large wind energy project, but the study noted that it did not service Fort Sill (Conover et al. 2004).

This analysis does not include any transmission costs and assumes that existing transmission lines are available to transmit power without substantial additional investment. It is also assumed that an on-site wind project would not trigger new standby or other fees from the local utility. However, because wind is intermittent, the utility may have interconnection requirements to ensure grid stability and to ensure there is reliable power for the installation.

Another consideration is potential interference with airport and air operations. Fort Sill has extensive airplane and helicopter training routes and radar systems. The area identified as having the best potential for development in the DoD Renewables Study, north of Deer Creek Canyon Road, is outside of the West Range Impact Area and at the time of the study, did not appear to conflict with any air operations. If this has changed, and there is interest in a large wind project, a site-specific, data-driven radar impact study could be done to determine the exact impact and address potential mitigation efforts, if required.

The Federal Aviation Administration (FAA) requires Notice of Proposed Construction for a project that meets certain criteria so that it can determine if there would be adverse impacts to air navigation safety. One of the triggering criteria is whether the project would be located within 20,000 feet (3.8 miles) or less of an existing public or military airport. When selecting an area for a wind project, it would be best to avoid this potential interference issue by locating the project outside of the 20,000-foot range. Any potential wind project would need to carefully consider this concern. An additional FAA criterion that would necessitate a Notice of Proposed Construction is any construction or alteration of more than 200 feet (61 meters) in height above ground level. This criterion applies regardless of the distance from the proposed project to an airport. 
In response to the filing of a Notice of Proposed Construction, the FAA can halt a project, require modifications be made to the project, or issue a "No Hazard to Air Navigation" determination and the wind project can proceed.

One potential compromise between air operations and wind energy project development, or a modification the FAA may request for a project, is the reduction in height of the wind turbines. This is most likely why the DoD Renewables Study calculated Fort Sill's long-term, hub-height adjusted annual average wind speed at $65 \mathrm{~m}$ rather than $80 \mathrm{~m}$, the typical height of $1.5-\mathrm{MW}$ turbines. A lower hub height may also reduce a wind project's visual impact, improving its chances of being approved by the Tribal Consultation Process.

This analysis considers four possible turbine sizes: a 1.5-MW turbine, a 100-kW turbine, a 10$\mathrm{kW}$ turbine, and a 2.4-kW turbine. The mid-size, small-size, and building-integrated size turbines were requested to be included in this analysis by Fort Sill. The hub height wind speeds for these turbines are estimated. Although the 2.4-kW turbine can be used on building roof-tops or other structures, this analysis assumes a standard ground installation.

\section{Wind: Economic and Other Analysis Parameters}

This assessment considered the current Federal wind incentives: a $2.1 \phi / \mathrm{kWh}$ renewable energy production tax credit (PTC) and 5-year accelerated depreciation. State-specific incentives applicable to wind energy projects for Oklahoma are also included and discussed in Appendix A.

During the DoD Renewables Study completed in 2004, the installed cost of capital was approximately $\$ 1,400 / \mathrm{kW}$; at the current time, prices range from $\$ 1,700$ to $\$ 2,600 / \mathrm{kW}$ because of high demand and increased costs for components. The capital cost was assumed to be $\$ 2,362 / \mathrm{kW}$ (including incentives and taxes) for this economic assessment for a large wind project.

For the other wind turbine sizes, a capital cost of $\$ 4,899 / \mathrm{kW}$ (including incentives and taxes) for the $100-\mathrm{kW}$ turbine was used, $\$ 6,533 / \mathrm{kW}$ (including incentives and taxes) for the $10-\mathrm{kW}$ turbine, and $\$ 10,389 / \mathrm{kW}$ (including incentives and taxes) for the 2.4-kW turbine. Fort Sill requested smaller turbines be included in the analysis. These exact turbine sizes were selected by PNNL because of their pricing and power curve information availability. Fort Sill is also interested in the possibility of using $25-\mathrm{kW}$ turbines, but pricing and power curve information was not available to be included in this analysis.

Because a wind energy project would provide intermittent power to the installation, the economics of a wind project are evaluated against the installation's direct energy charge of $1.36 \phi / \mathrm{kWh}$ to exclude demand and other fixed charges.

A wind energy project at Fort Sill would most likely be located on range lands. The marginal cost of energy on the range lands is $8.6 \phi / \mathrm{kWh}$. The project economics for the large-scale turbine are also evaluated against this rate.

The mean wind speed and net capacity factor determined in the DoD Renewables Study were reused in the updated analysis. 
Further details on the analysis methodology and the economic and incentive parameters are documented in Appendix A, and the assumptions used are listed in Table F-3.

Table F-3: Performance, Cost, and Economic Characteristics

\begin{tabular}{|c|c|c|c|c|}
\hline Location & Large Wind & Mid-Sized Wind & Small Wind & $\begin{array}{l}\text { Building- } \\
\text { Integrated Size }\end{array}$ \\
\hline Conditions & $\begin{array}{l}\text { Site-specific } \\
\text { conditions }\end{array}$ & $\begin{array}{l}\text { Standard: } 1.255 \\
\mathrm{~kg} / \mathrm{m}^{3} \text { air density, } 0 \\
\mathrm{~m} \text { ASL }\end{array}$ & $\begin{array}{l}\text { Standard: } 1.255 \\
\mathrm{~kg} / \mathrm{m}^{3} \text { air density, } 0 \\
\mathrm{~m} \mathrm{ASL}\end{array}$ & $\begin{array}{l}\text { Standard: } 1.255 \\
\mathrm{~kg} / \mathrm{m}^{3} \text { air density, } 0 \\
\mathrm{~m} \mathrm{ASL} \\
\end{array}$ \\
\hline $\begin{array}{l}\text { Assumed Average Wind } \\
\text { Speed }\end{array}$ & $\begin{array}{l}7.07 \mathrm{~m} / \mathrm{s} \text { at } 65 \mathrm{~m} \\
\text { calculated }\end{array}$ & $\begin{array}{l}6.55 \mathrm{~m} / \mathrm{s} \text { at } 37 \mathrm{~m} \\
\text { estimated }\end{array}$ & $\begin{array}{l}6.36 \mathrm{~m} / \mathrm{s} \text { at } 30 \mathrm{~m} \\
\text { estimated }\end{array}$ & $\begin{array}{l}6.03 \mathrm{~m} / \mathrm{s} \text { at } 21 \mathrm{~m} \\
\text { estimated }\end{array}$ \\
\hline Capacity Factor & Net: $29.7 \%$ & Gross: $29.9 \%$ & Gross: $27.5 \%$ & Gross: \\
\hline Turbine Type & $\begin{array}{l}\text { 1.5-MW, } 77 \mathrm{~m} \\
\text { rotor, } 65 \mathrm{~m} \text { hub } \\
\text { height }\end{array}$ & $\begin{array}{l}\text { 100-kW, } 21 \mathrm{~m} \\
\text { rotor, } 37 \mathrm{~m} \text { hub } \\
\text { height }\end{array}$ & $\begin{array}{l}\text { 10-kW, } 7 \text { m rotor, } \\
30 \mathrm{~m} \text { hub height }\end{array}$ & $\begin{array}{l}\text { 2.4-kW, } 3.7 \mathrm{~m} \\
\text { rotor, } 21 \mathrm{~m} \text { hub } \\
\text { height }\end{array}$ \\
\hline Project Size & 1 turbine & 1 turbine & 1 turbine & 1 turbine \\
\hline $\begin{array}{l}\text { Estimated Net Annual } \\
\text { Energy Production }\end{array}$ & $3,902,882 \mathrm{kWh} / \mathrm{yr}$ & $261,652 \mathrm{kWh} / \mathrm{yr}$ & $24,072 \mathrm{kWh} / \mathrm{yr}$ & $6,093 \mathrm{kWh} / \mathrm{yr}$ \\
\hline Energy Charge & $\begin{array}{l}1.36 \notin / \mathrm{kWh} \text { or } \\
8.6 \notin / \mathrm{kWh}\end{array}$ & $1.36 \notin / \mathrm{kWh}$ & $1.36 \notin / \mathrm{kWh}$ & $1.36 \notin / \mathrm{kWh}$ \\
\hline Total Capital Cost & $\$ 2,362 / \mathrm{kW}$ & $\$ 4,899 / \mathrm{kW}$ & $\$ 6,533 / \mathrm{kW}$ & $\$ 10,389 / \mathrm{kW}$ \\
\hline Annual Fixed O\&M Cost & $\$ 60 / \mathrm{kW}$ & $\$ 42 / \mathrm{kW}$ & $\$ 24 / \mathrm{kW}$ & $\$ 25 / \mathrm{kW}$ \\
\hline State PTC & $\$ 0.005 / \mathrm{kWh}$ & Not Eligible & Not Eligible & Not Eligible \\
\hline $\begin{array}{l}\text { 5-year accelerated } \\
\text { depreciation (MACRS) }\end{array}$ & Included & Included & Included & Included \\
\hline Federal $2.1 \phi / \mathrm{kWh}$ PTC & Included & Included & Included & Included \\
\hline REC Sales & Not Included & Not Included & Not Included & Not Included \\
\hline Transmission Costs & Not Included & Not Included & Not Included & Not Included \\
\hline
\end{tabular}

\section{Findings: Wind}

The various energy cost scenarios were evaluated for ECIP eligibility and IPP project potential. To qualify for ECIP funding, a renewable energy project must achieve a savings-to-investment ratio (SIR) of 1.0, and its payback is also examined. For the IPP evaluation, the commercial cost of energy was calculated to obtain an internal rate of return (IRR) of $10 \%$. This was used as the minimum IRR required to attract the interest of a wind power project developer. Table F-4 lists the results of these analyses. 
Table F-4: Economic Assessment of Wind Power

\begin{tabular}{|c|c|c|c||}
\hline Financing Scenario & \multicolumn{2}{|c|}{ ECIP } & IPP \\
\hline Economic Factor & SIR & Simple Payback, years & Cost of Electricity at 10\% IRR, $\varnothing / \mathrm{kWh}$ \\
\hline Large Wind, 1.5-MW @ 1.36 $\not \mathrm{kWh}$ & negative & negative & 12.92 \\
\hline Large Wind, 1.5-MW @ 8.6ф/kWh & 0.99 & 14.4 & 12.92 \\
\hline Mid-Sized Wind, 100-kW & negative & negative & 26.07 \\
\hline Small Wind, 10-kW & 0.01 & 922 & 37.52 \\
\hline Building-Integrated Size, 2.4-kW & 0.0 & 1,342 & 57.28 \\
\hline
\end{tabular}

Evaluated against the range land cost of energy, the 1.5-MW turbine is cost-effective per ECIP funding criteria. However, the range lands consume approximately $2.3 \mathrm{MWh}$ of electricity annually and the 1.5-MW turbine can produce 3.9 MWh annually. It is most likely that the excess energy produced on range land would have to be wheeled to the cantonment area and would displace electricity consumed on-site. To accurately model this scenario, the energy wheeled back and consumed on-site would have to be evaluated against the cantonment area's marginal cost of energy rate. The cantonment area's low marginal cost of energy makes this split consumption scenario uneconomic.

\section{Wind: Next Steps}

Although the analysis shows that wind energy projects at Fort Sill would have poor economics given the current cost assumptions and should not be pursued on the basis of economics, Fort Sill does have interest in wind energy and a moderate wind resource. Various factors could favorably affect project economics. If capital costs decrease, more incentives become available, or utility rates increase, or if project could be designed to economically displace only the range land energy consumption, Fort Sill should reconsider a wind energy project. In addition, a higher hub height for the large turbine would allow for increased energy production, which in turn would improve project economics. Alternatively, Fort Sill could consider pursuing a demonstration project as the site has many ideal characteristics for this type of development. Several sites have taken this approach and Fort Sill may benefit from their experiences.

For example, F.E. Warren Air Force Base (AFB) has a low cost of energy and strong wind resource, and has taken this demonstration project approach. F.E. Warren AFB currently has two Vestas 660-kW turbines and one 2-MW Gamesa turbine on-site. The turbines are tied directly to the base's power grid and provide some of the electricity needed to meet the base's power load. The two Vestas turbines generate over 4.4 million kWh of electricity annually (Booz Allen Hamilton 2007). The Gamesa wind turbine makes around 5 million to 6 million $\mathrm{kWh}$ of electricity annually. The Vestas turbines were installed and are maintained using ECIP funding (Simpson 2009). The Gamesa turbine was installed with \$4 million from the 2006 National Defense Appropriations Act as a demonstration project of a new-to-the-U.S. market, U.S.- 
manufactured wind turbine on an Air Force installation (Simpson 2009). Gamesa is a Spanish turbine manufacturer with facilities in Pennsylvania.

Using grant money for the procurement and installation of the 2-MW wind turbine at F.E. Warren ensured a successful project. With capital costs covered, this turbine can produce power economically, given the installation's low cost of energy (its marginal cost is currently $5.2 \phi / \mathrm{kWh}$ ), and only has operations and maintenance costs to consider going forward. According to a July 2010 NREL report, the Gamesa turbine is experiencing electrical problems and its warranty expires soon (NREL 2010). NREL recommends that F.E. Warren fix the turbine, develop a maintenance plan and capture lessons learned before embarking on a new turbine project.

Another example of a demonstration project is Fort Knox's 1.8-kW wind turbine. (The turbine is actually a $2.4-\mathrm{kW}$ turbine, but referred to as a $1.8-\mathrm{kW}$ because the turbine is never expected to produce more than that because of the site's poor wind resource.) The wind turbine produces approximately $1,000 \mathrm{kWh}$ per year. This translates to a capacity factor of about $6 \%$. This extremely low capacity factor demonstrates the poor wind resource of the area. Information was not available on the economics of this project, but it would be beneficial for Fort Sill to learn more about Fort Knox's project because of Fort Sill's interest in a possible micro-grid smallscale wind and solar PV project. Learning what, if any, incentives or other methods were used to reduce costs would be valuable.

Building-integrated wind turbines do not have a proven track record, although there is public demand for this application. There are many siting issues associated with roof-mounted turbines. For example, four 2.4-kW turbines were mounted on a 300-foot tall office building in Portland, Oregon. It was estimated that they would generate $10,000 \mathrm{kWh} / \mathrm{yr}$. However, in six months, they have only produced 2,371 kWh (Briscoe and Breshears 2010).

Because of Fort Sill's low cost of energy, the installation recognizes the challenge of developing cost-effective renewable energy projects. A possible approach to get renewable projects on-site is to develop them as demonstration projects. Installing a wind turbine can immediately bring attention from the local community to a site's commitment to renewable energy, if for no other reason than wind energy has become synonymous with "going green."

Fort Sill should look for demonstration opportunities and partners and monitor economic conditions so that a wind energy project may be pursued when circumstances permit.

\section{Wind Sources of Information}

AWEA - American Wind Energy Association. 2007. Wind Power Today. Accessed May 2010 at http://www.awea.org/pubs/factsheets/WindPowerToday_2007.pdf.

AWEA - American Wind Energy Association. 2009. Wind Power Outlook. Accessed May 2010 at http://www.awea.org/pubs/documents/Outlook_2009.pdf.

AWS Truewind. 2009. windNAVIGATOR. Accessed January 2010 at http://navigator.awstruewind.com/. 
Booz Allen Hamilton. 2007. Renewable Energy Enhanced Use Lease Opportunity Summary Report. Available at www.safie.hq.af.mil/shared/media/document/AFD-070917-021.doc.

Briscoe C and J Breshears. 2010. Building-Integrated Wind Turbines Lessons Learned. Poster Presented at American Wind Energy Association's WINPOWER 2010 Conference \& Exhibition. SGF Architects LLP, Portland, Oregon.

Conover K, KJ Smith, TM Jurotich. 2004. U.S. Department of Defense Renewable Energy Assessment Report of Wind Energy Potential On and Near Military Installations. Global Energy Concepts, Kirkland, Washington. Subcontract No: LAM-3-32257-01.

FAA - Federal Aviation Administration. 2007. Advisory Circular: Obstruction Marking and Lighting. AC 70/7460-1K, Federal Aviation Administration, Washington, DC. Accessed May 2010 at http://www.airweb.faa.gov/Regulatory_and_Guidance_Library/rgAdvisoryCircular.nsf/0/b993dc dfc37fcdc486257251005c4e21/\$FILE/AC70_7460_1K.pdf.

NREL - National Renewable Energy Laboratory. 2010. Final Report U.S. NORTHCOM Rocky Mountain Installations Renewable Energy Optimization Analysis. National Renewable Energy Laboratory, Golden Colorado.

OWPI - Oklahoma Wind Power Initiative. 2003. Oklahoma Wind Resource Map. Accessed January 2010 at http://www2.ocgi.okstate.edu/website/owpi2/viewer.htm (last update unknown).

PNL - Pacific Northwest Laboratory. 1986. Wind Energy Resource Atlas of the United States. Solar Technical Information Program \& Solar Energy Research Institute, Golden, Colorado. Available at http://rredc.nrel.gov/wind/pubs/atlas/atlas_index.html.

Simpson D. January 21, 2009. From wind to energy: New turbine construction. F.E. Warren Air Force Base, WY. Available at http://www.warren.af.mil/news/story.asp?id=123132150. 


\section{APPENDIX G}

Analysis of Shale Gas Opportunities 
Renewable Energy Opportunities at Fort Sill, Oklahoma

Pacific Northwest National Laboratory, March 2011 


\section{Appendix G: Analysis of Shale Gas Opportunities}

\section{Shale Gas as an Energy Resource}

Shale is a fine-grained sedimentary rock that is formed by compaction of an organic-rich mudlike substance that often accumulates at the base of stagnant water bodies by the settling of very fine particles that would otherwise remain suspended in moving water. During the compaction process, tiny microorganisms known as Methanogens begin the process of chemically breaking down organic matter, which produces biogenic methane as a byproduct in areas near the surface of the Earth that are void of oxygen. Methane that becomes trapped underground can then be recovered as natural gas. Another form of biogenic methane is landfill gas, which forms from the decomposition of waste materials broken down by methanogens through the same process.

Several wells recently installed at Fort Knox, Kentucky are currently producing biogenic methane gas from shale formations at 500- to 600-ft below ground (Meredith 2009). The methane gas produced at Fort Knox has provided substantial energy savings by replacing nearly all utility provided natural gas that was used to produce the domestic hot water requirements at Fort Knox (Meredith 2009). Successful shale gas production at Fort Knox has generated interest in exploring shale gas opportunities at Fort Sill, which is located in an area that has a similar geologic setting.

\section{Shale Gas Opportunities at Fort Sill}

Fort Sill is located within the Wichita uplift, a geologic sub-province of the Interior Plains of the Midwestern United States. The Wichita uplift is a structural and topographic high that formed as a result of continental collision during the Pennsylvanian Period (330-290 million years ago). Uplift during this time period produced several rugged mountain ranges, resulting in the separation of several major oil and gas basins in southwestern Oklahoma (Figure G-1). 


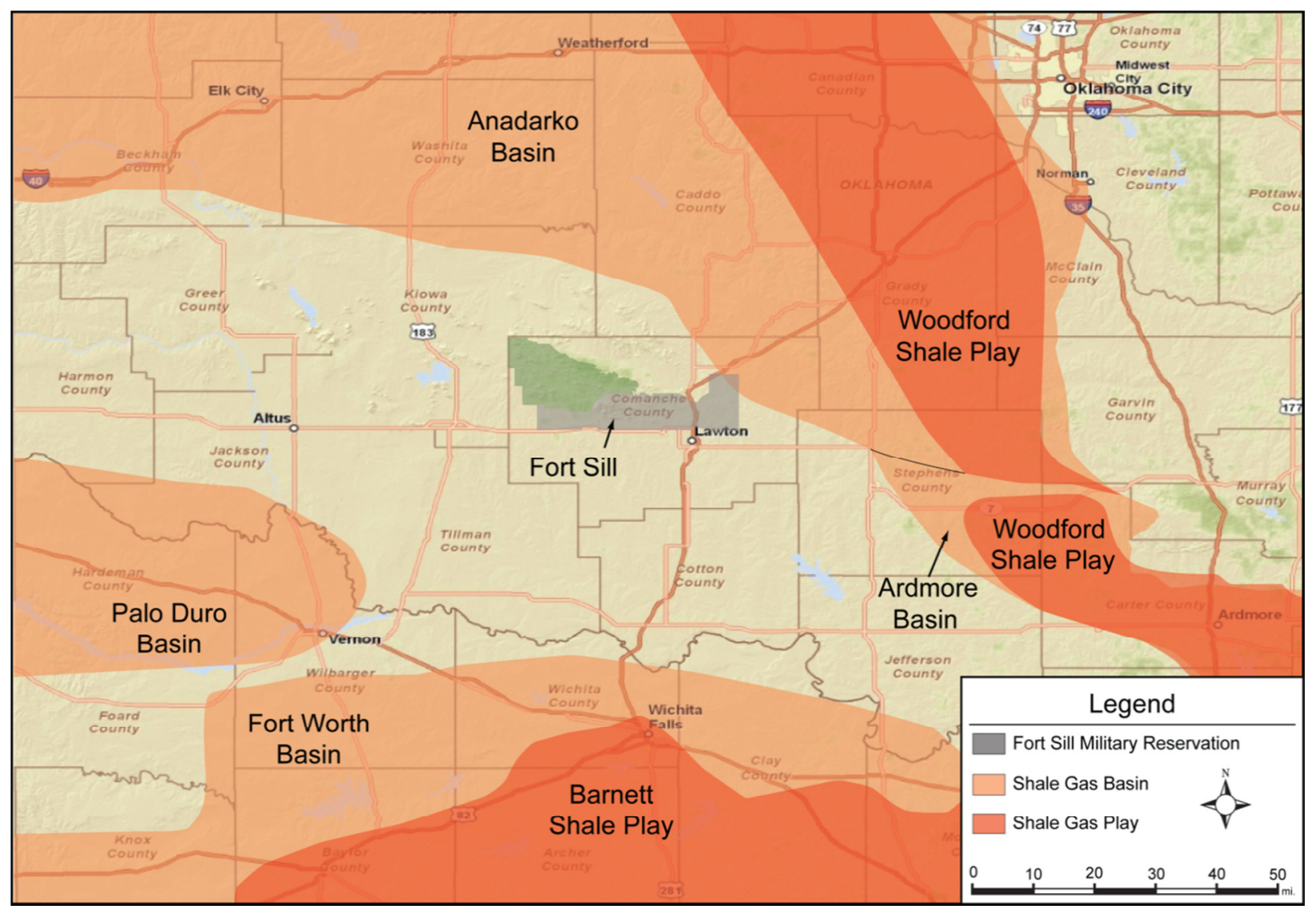

Figure G-1: Major Shale Gas Basins and Active Shale Gas Plays Located Near Fort Sill, Oklahoma (EIA 2010a)

The Anadarko Basin, which bounds the northern flank of the Wichita Mountains and contains a small portion of the northeast corner of Fort Sill, is a deep petroleum-rich basin that has been explored extensively across southwestern Oklahoma (Henry and Hester 1995). The Anadarko Basin primarily produces gas that is concentrated in isolated zones of porous and/or fractured rock, where it lies trapped by overlying rock formations with lower permeability, or by structural features such as faults and folds (Henry and Hester 1995). One of the most important hydrocarbon source rocks in the Anadarko Basin is the Woodford Shale. The Woodford Shale contains abundant organic matter and produces both oil and gas (Henry and Hester 1995). The thickness of the Woodford Shale beneath the northeastern corner of Fort Sill is estimated at approximately 400- to 500 -ft thick (EIA 2010b).

A detailed map of oil and gas fields located near Fort Sill (Figure G-2) shows that several oil, gas, and combined oil and gas fields are present near the eastern edge of the site. According to GeoCommunicator (2010), two actively producing oil and gas leases (\#OKM 0076849 and \#OKM0560471) are located just inside the eastern boundary of Fort Sill. 


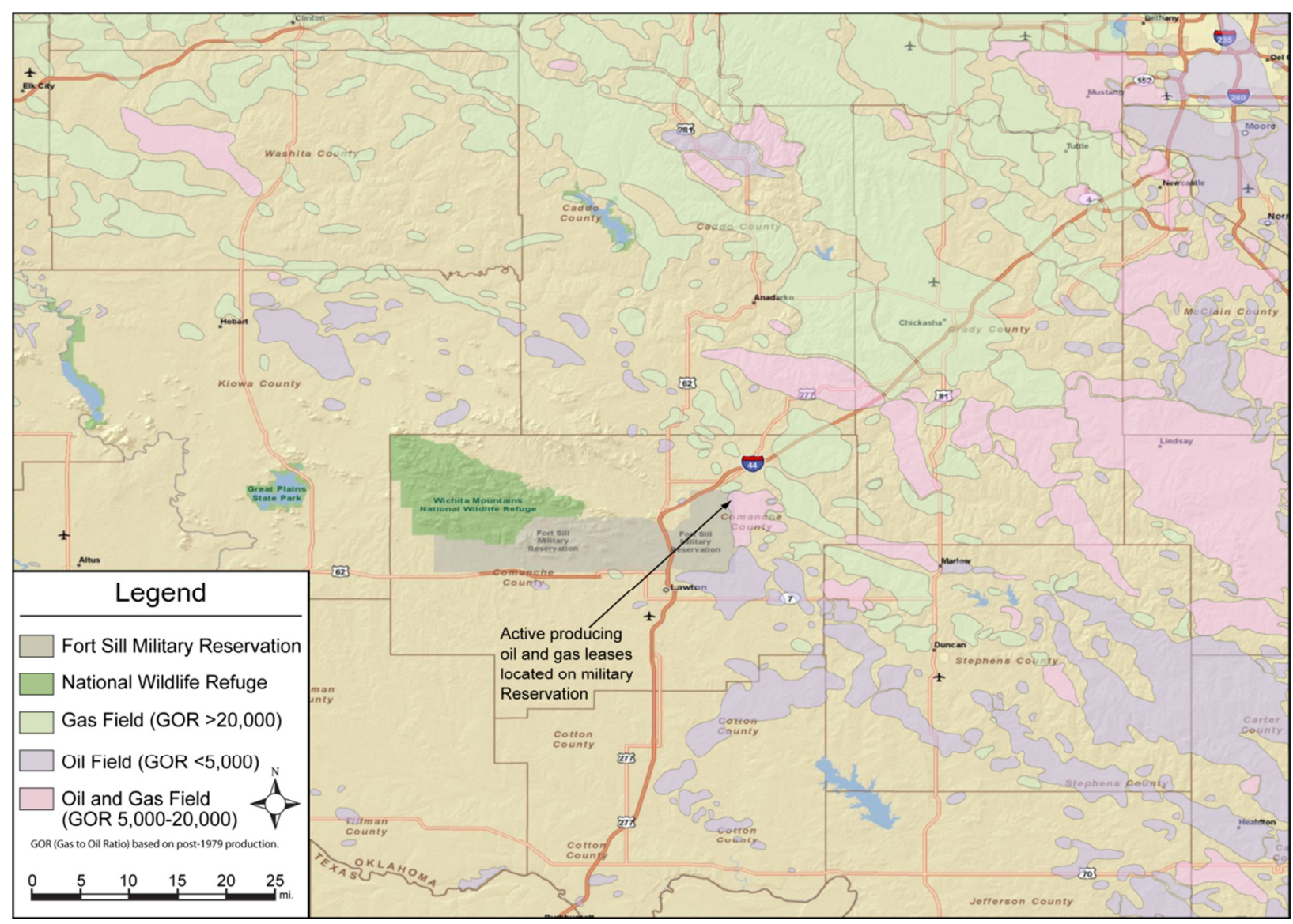

Figure G-2: Oil and Gas Fields Located Near Fort Sill, Oklahoma (Boyd 2002)

It is recommended that additional investigations into shale gas opportunities at Fort Sill utilize available well records and other published information for on-site and nearby oil and gas fields that could help identify the lithologic, structural and stratigraphic conditions of hydrocarbon rich source rocks beneath Fort Sill.

\section{Shale Gas Sources of Information}

Boyd DT. 2002. Map of Oklahoma Oil and Gas Fields (Distinguished by G.O.R. And Conventional Gas vs. Coalbed Methane). Oklahoma Geological Survey, Norman, Oklahoma. Accessed August 16, 2010 at http://www.ogs.ou.edu/level3-oilgas.php (last updated July 30, 2010).

EIA - U.S. Energy Information Administration. 2010a. Map of Active Shale Gas Plays, Lower 48 States. Accessed August 15, 2010 at http://www.eia.doe.gov/pub/oil gas/natural gas/analysis_publications/maps/maps.htm (last updated March 10, 2010).

EIA - U.S. Energy Information Administration. 2010b. Map of Woodford Shale Play, Anadarko Basin, OK and TX: Key Geologic Features. Accessed August 15, 2010 at http://www.eia.doe.gov/pub/oil_gas/natural_gas/analysis_publications/maps/maps.htm (last updated March 10, 2010). 
GeoCommunicator. 2010. Energy Map. National Integrated Land System (NILS) sponsored by the Bureau of Land Management and the U.S. Forest Service (USFS), Accessed at http://www.geocommunicator.gov/blmMap/Map.jsp?MAP=Energy on August 18, 2010 (last updated August 16, 2009).

Henry, ME and TC Hester. 1995. "Anadarko Basin Province (058)." in National assessment of United States oil and gas resources-Results, methodology, and supporting data, eds. DL Gautier, GL Dolton, LI Takahashi, and KL Varnes, U.S. Geological Survey Digital Data Series DDS-30, Release 2, one CD-ROM. http://certmapper.cr.usgs.gov/data/noga95/prov58/text/prov58.pdf. 


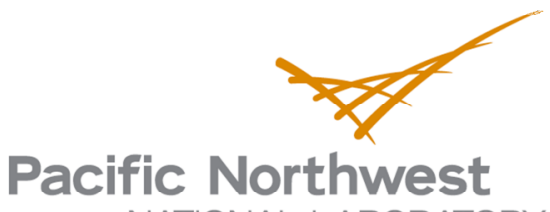

NATIONAL LABORATORY

902 Battelle Boulevard

P.O. Box 999

Richland, WA 99352

1-888-375-PNNL (7665)

www.pnl.gov
U.S. DEPARTMENT OF (ita) 